\title{
Education and the Racial Dynamics of Settler Colonialism in Early America
}

This is one of the first historical monographs to demonstrate the settler colonial paradigm's significance for Early American historical studies. Based on a nuanced reading of the archive, the book treats settler colonialism as a process rather than a coherent ideology. Spady shows that learning was a central site of a colonial struggle in which Native Americans, Africans, and European settlers acquired and exploited each other's knowledge and practices. Skills, attitudes, and ideas learned under settler-colonization shaped the economy and culture of the region. The colonized sometimes learned new ways to challenge colonial authority. Factions of African and Native American communities devised new survival and resistance strategies. White settlers gradually responded with a three-part pattern of racialization: settlers tried to prohibit literacy for the enslaved, eliminate Indigenous communities, and initiate some of North America's earliest schools for poorer whites. Fully instituted by the end of the 1820s, settler colonization's racialization of learning in the South endured beyond the Civil War and Reconstruction.

James O’Neil Spady is an associate professor of American History at Soka University of America in Aliso Viejo, California. 


\section{Routledge Advances in American History}

The Conservative Movement and the Vietnam War The Other Side of Vietnam

Seth Offenbach

The Liberal Dilemma

The Pragmatic Tradition in the Age of McCarthyism

Jonathan Michaels

Reagan's "Boys” and the Children of the Greatest Generation U.S. World War II Memory, 1984 and Beyond Jonathan M. Bullinger

Perceptions of China and White House Decision-Making, 1941-1963 Spears of Promise, Shields of Truth Adam S.R. Bartley

A Brief History of the Subordination of African Americans in the U.S. Of Handcuffs and Bootstraps Alexander Polikoff and Elizabeth Lassar

Education and the Racial Dynamics of Settler Colonialism in Early America

Georgia and South Carolina, ca. 1700-ca. 1820

James O’Neil Spady

The Overseers of Early American Slavery

Supervisors, Enslaved Labourers, and the Plantation Enterprise Laura R. Sandy

For more information about this series, please visit: www.routledge.com/ Routledge-Advances-in-American-History/book-series/RAAH 


\section{Education and the Racial Dynamics of Settler Colonialism in Early America Georgia and South Carolina, ca. 1700-ca. 1820}

\section{James O’Neil Spady}


First published 2020

by Routledge

52 Vanderbilt Avenue, New York, NY 10017

and by Routledge

2 Park Square, Milton Park, Abingdon, Oxon, OX14 4RN

Routledge is an imprint of the Taylor \& Francis Group, an informa business

(C) 2020 Taylor \& Francis

The right of James O'Neil Spady to be identified as author of this work has been asserted in accordance with sections 77 and 78 of the Copyright, Designs and Patents Act 1988.

All rights reserved. No part of this book may be reprinted or reproduced or utilised in any form or by any electronic, mechanical, or other means, now known or hereafter invented, including photocopying and recording, or in any information storage or retrieval system, without permission in writing from the publishers.

Trademark notice: Product or corporate names may be trademarks or registered trademarks, and are used only for identification and explanation without intent to infringe.

Library of Congress Cataloging-in-Publication Data

Names: Spady, James O’Neil, 1968- author.

Title: Education and the racial dynamics of settler colonialism in early America : Georgia and South Carolina, ca. 1700-ca. 1820 / James O’Neil Spady.

Other titles: Routledge advances in American history ; 16.

Description: New York, NY : Routledge, 2020. I Series:

Routledge advances in American history; 16 | Includes

bibliographical references and index.

Identifiers: LCCN 2019054388 (print) I LCCN 2019054389

(ebook) I ISBN 9780367437169 (hardback) I ISBN

9781003005247 (ebook) I ISBN 9781000047318 (adobe pdf) I

ISBN 9781000047325 (mobi) I ISBN 9781000047332 (epub)

Subjects: LCSH: Whites-Georgia-Relations with IndiansHistory. I Whites-South Carolina-Relations with Indians-History. I Slaves-Education-Georgia-History. I Slaves-Education-South Carolina-History. I Racism in education-Georgia-History. I Racism in education-South Carolina-History. I Georgia-Race relations-History. I South Carolina-Race relations-History.

Classification: LCC F295.A1 S69 2020 (print) I LCC F295.A1 (ebook) I DDC 305.8009758-dc23

LC record available at https://lccn.loc.gov/2019054388

LC ebook record available at https://lccn.loc.gov/2019054389

ISBN: 978-0-367-43716-9 (hbk)

ISBN: 978-1-003-00524-7 (ebk)

Typeset in Sabon

by Apex CoVantage, LLC 


\section{Contents}

List of Figures vi

Acknowledgments and Dedication viii

Introduction: "Like the Spider From the Rose" 1

\section{PART I}

Colonization and Learning to Circa 1770

1 An Overview of the Formation of a Settler Society 29

2 Learning as a Practice of Power by the Colonized 57

3 Emulation and Whiteness

\section{PART II}

Colonization and Learning After Circa 1770

4 An Overview of a Republican Settler Society 135

5 Toward New Echota, Toward First African 152

6 The Race of Learning 192

Coda: Settler Colonial Modernity and Dangerous Learners

Appendix: A Note on the Primary Sources 


\section{Figures}

I.1 Map showing the "Indian Boundary Line" running just west of Georgia's coastal rice-growing parishes, populated by local slave majorities, 1780 .

$\mathrm{x}$

1.1 Detail of a 1640 map showing the "Lower South" before extensive European colonial settlement. Pictured is part of what would become South Carolina and Georgia. Errors and missing information reveal the depth of colonial ignorance about the geography.

1.2 Savannah, a disciplinary institution without walls, as its plan and design looked in the 1730s.

1.3 The "Catawba Map."

2.1 Detail of a 1720s map of the Lower South, showing parts of South Carolina. Compare its representation of the "Waterees" and other Native names, as well as the "Road to Virginia," to the Catawba Map (Figure 1.3).

3.1 Images of Bethesda projected discipline, respectability, and order-an exemplar of colonization as reform and Christianization.

4.1 A 1776 map of the Lower South, representing clearly defined boundaries for South Carolina and porous, ambiguous boundaries for Georgia.

4.2 Detail showing Georgia's western boundary with the Creeks (center left and lower left).

5.1 Detail of an 1823 map showing Cherokee and Creek homelands represented as part of Georgia. The Spring Place Mission was in the Cherokee homeland claimed by Georgia.

5.2 Mulberry Plantation, South Carolina. Image shows the slave quarters and the main house, revealing African and Anglo-inspired architectural elements, especially in the rooflines. View of Mulberry, House and Street, ca. 1800, by Thomas Coram (American, 1756-1811); Oil on paper; Museum purchase; 1968.018.0001; Image courtesy of the Gibbes Museum of Art/ Carolina Art Association. 
6.1 Detail of a map of Williamsburg District from the 1820s showing Indian Town as well as a "School H." to the east, along the road from Indian Town and near Lynches Creek.

6.2 Detail of a map of Pendleton District, 1820s, showing a putatively undeveloped portion northwest along the Georgia border and beside Cherokee land. Note the meeting houses ("M.H.") as well as the "Poor House," south along the road out of Pendleton.

C.1 Cherokee constitution of 1827 at New Echota, in English (left) and Cherokee (right). Courtesy, American Antiquarian Society. 


\section{Acknowledgments and Dedication}

Writing a book incurs many debts to people and institutions. Completing the process offers the chance to express thanks and give credit. I thank the numerous librarians, scholars, and colleagues at the South Carolina Department of Archives and History, the College of Charleston, University of South Carolina, the South Carolina Historical Society, the South Caroliniana Library, the Hargrett Reading Room at the University of Georgia, Duke University Special Collections, the Southern Historical Collection at the University of North Carolina, the New York Public Library, the University of Southern California's "American Origins" series, the Huntington Library, the College of William and Mary, and the Omohundro Institute of Early American History and Culture. I thank my friends and comrades in the Tidewater Labor Support Committee, Chicanxs Unidxs, and the United Electrical Workers Local 160.

Many conference commenters, peer reviewers, and editors responded to various portions and iterations of this work over the years. I hope they will see how their criticisms and suggestions improved the work. Soka University of America provided significant research and travel funding, and my colleagues supported the development of relevant seminars. A few specific people read drafts and without them this book would possibly never have been complete: Robert A. Gross, Peter Mancall, Leisa Meyer, Andrew Newman, Bill Pencak, Terri Snyder, Frederika Teute, and Karin Wulf. It is a pleasure to acknowledge Soka colleagues who advised me: Shane Barter, Esther Chang, Sarah England, Jay Heffron, Dongyoun Hwang, Orin Kirshner, Ian Read, and Michael Weiner. Several colleagues in the SMR reading and discussion group at Soka were especially important: Ryan Caldwell, Tomas Crowder-Taraborrelli, Aneil Rallin, and Kristi Wilson. I also want to acknowledge Alex Scott and Khin Thazin, research assistants who contributed most significantly to the completion of this manuscript. Many other students contributed directly and indirectly to this work, most of them without knowing it, I imagine. I cannot name them all here, but I am grateful to each. Teaching is also inquiry, and teachers learn from students. 
Most importantly, I wish to thank and acknowledge Wendy Gonaver. More than anyone, she read and edited drafts. Her intellectual contributions are too numerous to list, and her general support is too valuable to describe adequately in this confining format. I will forever be grateful.

Portions of Chapter 1 were previously published as "Bubbles and Beggars and the Bodies of Laborers: The Georgia Trusteeship, White Labor, and the Cultural Politics of Colonialism," in L.H. Roper and Bertrand Van Ruymbeke, eds., Constructing Early Modern Empires: Proprietary Ventures and the Origins of the Atlantic World, 1500-1750 (Boston: Brill, 2007), 213-268. Portions of Chapter 3 were previously published as " 'To Vie with One against Another': Race and Demand for Non-elite White Education in an Eighteenth-Century Colonial Society," Early American Studies (2011), 649-676, and remains under copyright by the McNeil Center for Early American Studies at the University of Pennsylvania. All rights reserved.

I dedicate this book to my brothers and especially to our mother: aller anfang sind schwer. 


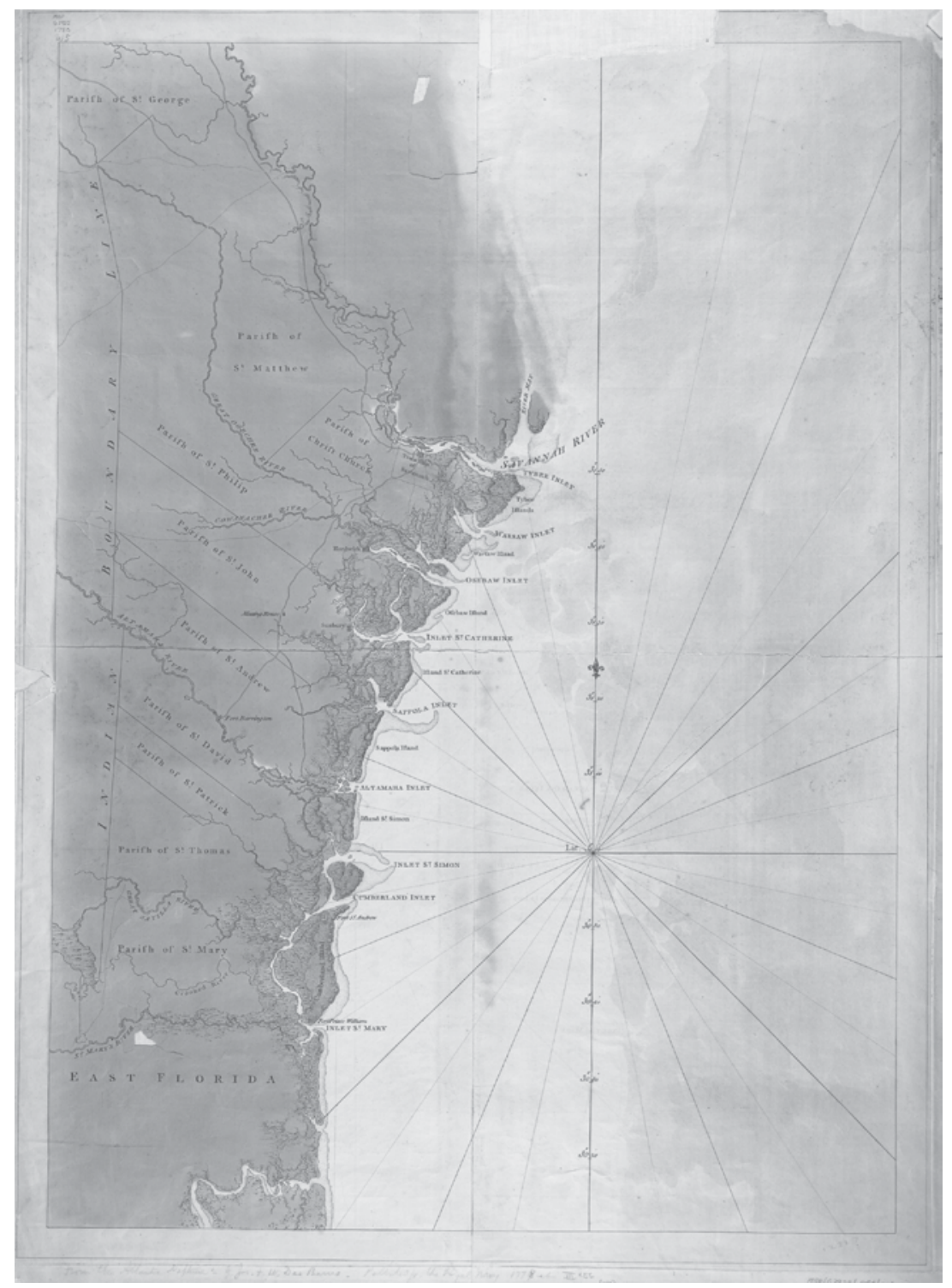

Figure I.1 Map showing the "Indian Boundary Line" running just west of Georgia's coastal rice-growing parishes, populated by local slave majorities, 1780.

Source: [Coast of South Carolina and Georgia from Stono River to Inlet St. Mary] by John Wilson, 1780. Courtesy of Hargrett Rare Book and Manuscript Library/University of Georgia Libraries. 


\title{
Introduction
}

\section{"Like the Spider From the Rose"}

\begin{abstract}
We want a School-master in my parish for our White peoples children but as for the Negroes or Indians with all submission I wou'd desire that such a thing shou'd be taken into Consideration as the importance of the matter and the Consequences wch. May follow do deserve. The Best scholar of all the Negroes in my Parish . . . thro' his Learning was like to Create some Confusion among all the Negroes.
\end{abstract}

- The Rev. Francis LeJau in South Carolina in $1710^{1}$

A missionary in South Carolina working with an Indigenous man complained that Christians in England often emerged from religious study "like the Spider from the Rose ... overcharg'd with Poisons" and intoxicated with "erroneous" ideas. Unlike many English people, his new Native American convert had made a declaration of belief from which the missionary hoped all people-including English people-would learn. The minister's didactic distinctions between error and rectitude revealed those qualities that he thought worthy of emulation in the Native convert: humility, rational understanding, and a desire to teach the Gospel. ${ }^{2}$

Another missionary encountered an enslaved man he considered an exemplar of dangerous conversion. The newly converted African predicted that the moon would soon turn as red as blood, a harbinger of judgment against sinners. Some slaves in the neighborhood decided that the man was a prophet, according to the colonial missionary's version of events. The missionary condemned the use of the Bible to promote a vision of apocalyptic judgment upon English colonials. He condemned it even though many masters resisted teaching slaves Christianity. Though he also privately agreed about the sinfulness of slave masters, the accusation seemed dangerous from the mouth of a colonial slave. Thereafter, he altered his approach to instructing the colonized and enslaved. He concluded that Africans and Native Americans were often not fit for Christian learning. They acquired intoxicating lessons that no teachers were teaching. In his view, it was better to individually and methodically assess 


\section{Introduction}

the temper of enslaved and Native people and bar those of inappropriate character from Christian instruction. ${ }^{3}$

These two very different conversion stories reveal a relationship between learning and power that had enormous consequences for British North America and the early United States. Power and learning affected each other dynamically. Colonization implicated learning in contested relations, unequal dialogues, and exploitative situations. Learning was creative, critical, and interpretive. It produced knowledge that was consequential, leading to resistance but also collaboration and new, hybrid cultures. Learning by the colonized was sometimes unpredictable to colonials. This potential and uncertainty in learning and its role in history and culture reopens long-standing questions about the significance of conversion, agency, assimilation, and resistance by colonized people in Early America. The question is no longer how "authentic" were the conversions of Native or African people to Christianity, nor is it whether conversion was instrumentally about resistance. The question is about how learning was productive of new relations of power. Conversions must be examined as part of a broad spectrum of learning that remade the cultures of the colonized and the colonial. Instead of thinking of knowledge as a product-as an immutable thing-we can think of knowledge as constantly evolving actions generated by learning. Thought of as an activity, we can see learning as open-ended and ask how it was incited, interpreted, and disciplined by people engaged in power struggles for control over body, community, or land. Why did people learn what they chose to learn? How did a body of knowledge change when its cultural context changed? When colonized learners make knowledge rather than merely receive it, how does that alter relations of power? How do colonials react? Answering these questions requires that we explore the history of colonization and the history of learning as linked histories.

This book treats learning as an activity that is broader than formal education, which entails specific and defined curriculum acquired from a teacher or an authoritative text. Learning happened within such settings and institutions, but it also happened without them. Learning was how people inherited discourses and practices from relatives. Learning occurred as creative realizations, regardless of whether anyone was teaching. As a behavior, it is how culture is retained and how it is created anew. It was therefore the nexus wherein colonization became embodied and challenged, sometimes unpredictably. During the eighteenth and early nineteenth centuries, this book argues, the unpredictable learning of poorer colonials and the colonized catalyzed both disciplinary inclusion (school access) and punitive exclusion (prohibitive law) as part of an effort to manage how populations lived by managing what and how they learned.

Over time, colonials created racial typologies that prescribed appropriate and inappropriate learning for poorer "whites," for "Indians," and 
for "Negroes" in colonial society. However, lines of distinction between these categories were always contested and somewhat unstable. Only colonial whites possessed the rights and privileges of British subjects, but all Christians were expected to convert non-Christians. For Protestants, conversion usually required at least some reading of the Bible. Therefore, one could not easily endorse making the enslaved Christian while completely banning reading by the enslaved. All people living in colonial society contested these nuances. As expansion of the colony challenged how colonial and colonized people understood their lives, it rearranged their differences and similarities. Learning from each other revealed and reinvented differences even as learned skills—such as hunting, rice cultivation, or English literacy-became shared by cross-cultural groups of Native, European, and African people. Trade and exchange necessitated learning that resulted in cultural change. As Native men learned to trade deerskins for gunpowder or as Native women learned to grow corn for a market, they adapted Atlantic trade to their struggle to defend political autonomy, a land base, and their gendered social order. As white colonials met Native people whose learning made them savvy about how to negotiate, whites themselves had to learn to adapt. Similarly, when an enslaved African convert learned Christian doctrines, he or she became adept at utilizing Christian discourses without necessarily acquiring a willingness to submit to enslavement and the colonial order. For example, a converted Baptist, referred to only as "Negro Phil" in documents, learned Moravian theology from missionaries working among Creeks in the early nineteenth century. His knowledge of Christianity ironically sharpened his differences with the missionaries regarding their colonial project. "Negro Phil" struggled with the moral implications of colonization and predicted that God would judge colonials harshly for their sins. The Moravians dealt with him mostly as a disciplinary problem. ${ }^{4}$ It is out of such dynamics of learning and power that many of the nuances of North American racism emerged.

Learning did not require teaching. Learning was how people made sense of colonization's alienating changes to everyday life. Learning did not require school. Even a person in a school who utterly failed to learn what instructors were teaching would nonetheless have learned. People learned, and the results of that learning-academic or technical skills, solutions to problems, adjusted attitudes, strategic decisions, and renewed values-changed relations of power. All the lifeways and resources for meaning that colonized and colonial people devised were consequences of learning. This book argues that learning behaviors and outcomes gradually became targets of education reform policies and practices because learning could, and sometimes did, challenge colonial projects. Nonelite whites, Natives, and enslaved people were each affected as relatively elite whites such as missionaries or plantation masters proposed formal education to relieve "ignorance" or make populations more useful. 


\section{Introduction}

Such instrumentality calls to mind Aimé Césaire's noted formulation that "colonization $=$ thingification." It also suggests what David Brion Davis once declared to be the central problem of slavery: the untenable effort to make people into things. "Thingification" appeared whenever colonial education promoters sought to shape people's learning for the instrumental purposes of colonial society, attempting to discard the rest of people's learning as ignorance, chipping it off like a sculptor manipulating a stone. ${ }^{5}$

This history of learning affected the development of race and educational modernity. By educational modernity, I mean the practices and policies governing the general population's learning through regulations, prohibitions, and access to free schools. Everywhere that schooling of entire populations has emerged over time, it has proposed to shape how people live by shaping what they learn. Why schooling emerged in the Lower South when it did, how efforts to shape learning unfolded, and how to identify the ways in which conflicts over learning affected educational innovation and racialization are the central questions of this book. ${ }^{6}$ Three related and interlocking arguments, supported by extensive archival research, provide answers to these questions.

First, Euro-American elites came to believe over time that they needed methods and institutions to order the learning of African American, Native American, and poor white populations. Partly because learning was a pathway through which colonized and nonelite whites contested colonial aims, learning also became a focus of efforts to make more useful laborers, allies, subjects, citizens, or converts. Prohibitions against slave literacy were not a product of colonial ignorance about Africans' ability to learn; they were, rather, a tactic resulting from the colonial understanding that African learning was a problem for the safety of colonial settlers and projects. Gradually, I argue, elite regulations for slaves', Native Americans', and poorer whites' learning diverged from each other as the discourses and practices of race developed.

A second, related argument explores how various nonelite people learned to maneuver within settler colonial society. Their learning was often practical, sometimes tactical, and occasionally sharply subversive of colonial projects. It was a hybrid knowledge that sometimes threatened colonials, especially elite colonials. These threats-including the mere perception of danger-could emerge even when learning was not premeditated or offered as resistance. Hybridity, as suggested by Homi Bhabha, is the conscious or unconscious practice of denying, deflecting, or deferring submission to a subordinating power. Hybridity often appears as if in code because it adopts enough of a colonial cultural form or practice to become difficult for colonials to know how, or even whether, to insist on a more complete submission. Hybridity is like creolization in some respects, but with relations of power understood as the core 
concern. Unlike creolization, hybridity is not attuned to observing the development of a "culture" as a system. Rather, it helps identify traces of colonial power in cultural practices and discourses. Hybrid learning in the Lower South might be institutionalized as an all-black Methodist church or a Cherokee state with its own constitution. To find the hybridity in such cultural forms is to trace the dynamism, nuance, creativity, and critical consciousness of the people who produced them. It is also to locate losses that the colonized suffered during colonization. Paradoxically, their learning sometimes enhanced exploitation. For example, learning regional topography might help the enslaved resist via flight into the woods or swamps, but it also made enslaved workers more valuable as boatmen, couriers, or draymen. Learning increases the stakes in relations of power. ${ }^{7}$

The third and final argument of this book is about how the increasing stakes for colonial projects brought on by the learning/power nexus helped catalyze the racialization of education. The learning/power dynamics of colonization in the eighteenth century incited the desire to shape how people lived-contributing to the birth of modernity in education itself. The subsequent learning/power dynamics of colonial society drove both the exclusion of Native and African people from formal education and the creation of state-supported schools for nonelite whites. Poorer whites and wealthier whites created institutions and prohibitions that assisted in constructing whiteness over and against black and Native racial identities. These potent race distinctions reciprocally reinforced the unequal distribution of privileges and pain. Two generations of scholarship have shown that the "race concept" developed over a protracted period of time from the seventeenth through the nineteenth centuries. In practice, race distinctions were corollaries of colonization's assertions of entitlement to Indigenous land and African labor. In the Lower South, people created local practices "to divide the world." Race was a learned doctrine and practice deduced from the details of countless struggles between colonial and colonized people. Native and African hybrid learning sharpened colonial desire to exclude or subordinate them as "savages" and "barbarians." Crucially, this desire also helped incite education initiatives for poor whites. Colonization, I argue, advanced modern education in the region because colonials feared poorer whites would become "savage" or "uncivil" and therefore unreliable, immoral, or unruly. A racial pattern emerged in the governance of learning before the American Revolution: expanded initiatives for poor white institutional education alongside intensified efforts to prohibit or marginalize that same basic education among Native and African people who might desire it. This pattern became sharper after the American Revolution, helping to produce the political climate for the expansion of free schools for poor whites. ${ }^{8}$ 


\section{Introduction}

\section{Defining Colonial Society}

Terms such as colonization, settler colonialism, and colonial society require definition. Colonization is the process of expanding a colony within an empire, broadly conceived. I use it interchangeably with settler colonialism in this book. Both terms refer to a mode of empire in which settlers arrive and never return to the mother country. A settler colonial society, as I am using the term, is a society suffused by colonial processes. In the Lower South, settlers embraced chattel slavery so extensively and intensively as to produce what Philip D. Morgan has called a "slave society." This commitment to enslavement was equally a commitment to settler replacement of native people. Both its black majorities and its powerful Native towns and confederacies were formative in the history of the region in the eighteenth and early nineteenth centuries. Black majorities were frequently composed of people born and raised in Africa. Powerful North American Native towns and confederacies had far-reaching effects upon commerce, political affairs, diplomacy, and cultures in Georgia and South Carolina. Consequently, the dangers and expectations of colonization were often already present in everyday relationships. A perfectly fair trade between a Native hunter and a Carolina trader would nevertheless have dimensions of power that must be appreciated to fully understand the significance of the exchange for all the parties. Colonials steadily demanded deerskins, land, or military assistance from their Native interlocutors-requests that colonials expected to be filled. Natives could and did refuse at times. At other times, they made their own counter-demands. These regular initiations of demand created a pattern of dynamic colonial expansion that scholars have long appreciated. Similarly, the demand for slaves dramatically altered European trade in Africa. It created profits for colonial traders and African middlemen while also resulting in social death for the enslaved. African middlemen maneuvered for position against specific colonial rivals, but European appetite for humans as slaves became relentless. In fact, its persistence made the trade profoundly colonial. Georgia and South Carolina became deeply embedded in what Sven Beckert has recently termed war capitalism at the more global level. The colonial dynamics of this predicament reached and refracted almost every relationship and structure in settler society-including learning. ${ }^{10}$

Learning was agonizing because daily life featured significant diversity, intimacy, and exploitation. Africans of a wide variety of ethnicities and Indigenous Americans from different towns, confederacies, and language groups encountered each other and settlers from several European nations and religious sects. To live in the Lower South during the eighteenth and early nineteenth century was to live in frequent contact with each other, or else to be actively engaged in colonial enterprises. As late as 1780, the "Indian Boundary line" in Georgia was still just a few miles west of the 
Atlantic Ocean and the tidewaters where the enslaved labored on plantations (see Figure I.1). It was a life frequently punctuated with dramas arising from the expansion of colonial projects. Colonial settlers pursued their ambitions through negotiation, legislation, policing, and war. For their part, colonized Native American and African peoples lost homelands: one through diaspora out of the coastal southeast and the other through diaspora into the region. Both Native and African people had to parry the worst colonial desires by adapting through long-term, intergenerational learning. People reconceived the practices of their daily lives in order to form new strategies in changed circumstances. This book's exploration of the history of this learning brings together several strands of scholarship on Early America in a way that seeks to "think about the broader context of colonization" by comparing imperial and colonial projects. Building on the work of Ann Laura Stoler, Julian Go, Walter Hixson, and others, we can view this learning-social and intimatethrough the prism of global imperial and colonial development. ${ }^{11}$

People in the Lower South had little choice but to compare their cultures and communities with others. It was almost a requirement, not merely a side project of the traveler with a facility for writing. First, there were many competing sovereignties whose claims overlapped and worked by different rules. Chickasaw, Cherokee, Creek, and Catawba confederacies were among the first inhabitants, and they competed and sometimes warred against one another. Layered on top of this Indigenous politics, the Spanish and English developed conflicting claims that sometimes precipitated wars over borders, conflict over runaway slaves, and competition for the loyalties of Native Americans. A second set of reasons for comparison arises from the fact that the region encompassed a large enslaved population, multiple ethnicities, and diverse religious sects. Living in the region were Gola, Mende, and Vai; English, Spanish, and German; and Cherokee, Creek, and Catawba (to name only some of the more significant groups). Furthermore, from Senegambia to Ghana and the Kingdom of Kongo, knowledge of statecraft, rice culture, and ironworking was more developed than was the case in parts of Europe and elsewhere. Implicitly and explicitly, colonials compared their own knowledge and property with that of people they encountered. Colonization of North America therefore featured many layers of comparison. As Amy Kaplan has written, the "frontier" has been revised "from the vacant space of the wilderness ... to a site of contacts, encounters, and collisions." The "frontier" produced new hybrid cultures. Representing and explaining some of the evidence for how this frontier contributed to the development of schooling institutions and racialized learning requires a comparative approach. ${ }^{12}$

Strategic learning could result from comparisons. Native and African learning that provided powerful skills or was associated with respectability in the colonial world challenged the colonial project of profitable 


\section{Introduction}

expropriation of labor and land. Such learning could become a target of hostility. Learning by the colonized always carried with it the possibility of undermining the European claim that darker complexions indicated a body incapable of learning beyond a limited sphere. ${ }^{13}$ Racial typologies were still only developing in the eighteenth century, but whenever learning reduced distinctions by erasing skill and knowledge differences, the nascent logic of race was undermined. But if Africans and Natives could learn Christianity or literacy and thus enhance their ability to defend their land base or regain their freedom through the colonials' own culture, then colonial expansion and stability encountered a material problem. The Lower South developed a regionally specific, racializing modernity in response. The region became a site for promoting methodical interventions into learning processes that buttressed differences between poorer whites, Natives, and Africans. Methods that shape learning without necessarily resorting to physical violence can transform how a life is lived by simultaneously increasing both aptitude and domination. Over generations, a wide range of emotions, values, and ideologies of the living can be hybridized and reconstructed. Any move toward methodical intervention was a move toward trying to govern learning. The rise of an interest in such techniques must be understood within the context of the colonial struggle in which they appeared. ${ }^{14}$

This comparative approach has rarely been tried, though interest has been growing. Until recently, U.S. historians only compared AngloAmericans with Africans or Native Americans. Scholars have centered analysis on Native or enslaved people in relative isolation from each other, although some have explored Native/African interactions and intermarriage. A few studies have focused on the "three races." The intellectual history of Euro-American scientific racism aside, in all cases the logic of comparison has assumed that only direct encounter between people justifies comparison. Comparisons have also tended to emphasize cultural survival or loss. Direct encounter is important, as is the story of loss and survival. Yet as Tiya Miles, Claudio Saunt, and others have demonstrated, new modes of comparison could yield significant historical insight. ${ }^{15}$ As Edward Countryman has observed, the long postRevolutionary disaster for Native Americans paralleled the 50-year working out of the American Revolution's "liberating implications" for white men. Countryman has suggested that these two narratives might be related and urged exploration of how these themes "intertwined ... with the expansion of black American slavery." Efforts to govern learning and movements toward institutional education sit in that intersection of the three paths: colonization, race formation, and nation building. It is an intersection of republican inclusion and racial exclusion. Robert Blair St. George has also called for "detailed and comparative examinations" of colonialism in practice in Early America. This book follows these lines of curiosity. ${ }^{16}$ 
Thinking comparatively about learning and power produces fresh assessments of well-known events. For example, the Stono Slave Rebellion of 1739 has long been understood to have African dimensions, demonstrated most clearly in the drumming that the documents describe. Stono rebels probably learned their martial skills in the Kingdom of Kongo before their enslavement. As military veterans enslaved in the Carolina colony, they learned the geography and imperial politics of the Spanish/English rivalry in the region and then exploited this knowledge. They learned the importance of the concept of "liberty" in English and to the English and forged a distinct understanding of it featuring both African and colonial roots. When the 1740 South Carolina slave law that responded to the rebellion banned teaching Africans to write, legislators used the crisis as an opportunity to exclude the enslaved from a powerful skill. The legislators probably would have banned reading too if not for the objections of missionaries. Yet there was no evidence that reading or writing played a role in catalyzing the rebellion. So why did they single out writing? A possible answer is that the crisis created by the rebellion built the consensus needed to govern the learning of the enslaved with new vigor. Exclusion from writing-like a brand mark-could further distinguish the enslaved from Anglo-Americans. Going one step further, South Carolina whites also set the enslaved further apart from other Africans when they banned drumming. In West Africa and West Central Africa, drumming was a communication skill. Unlike writing, drumming is specifically cited as a technology that the Stono rebels used. Scholars have noticed both the writing and the drumming prohibitions but have not recognized how these exclusions and the myriad other regulations on the movements and activities of the enslaved were consistent as elements of an emergent practice of governing learning in general. Together, such prohibitions helped shape the enslaved into a marginal and subordinate class-a caste (a race). Such interventions into learning, repeated in countless ways, helped construct racial demarcations between whites, blacks, and Native Americans. ${ }^{17}$

The learning/power nexus of settler colonialism reconstructed "sentiments and desires" on all sides through a contested history. The negotiated nature of power in Early America has long been recognized in several historical subfields. ${ }^{18}$ Among American historians who have studied slavery, ${ }^{19}$ Native Americans, ${ }^{20}$ women, ${ }^{21}$ and the "plain folk" 22 in the South, evidence from the archive has been martialed to demonstrate that culture and power were contested, negotiated, or resisted by a variety of nonwhites and poorer whites. The relative position of these nonelite peoples within settler colonial society's relations of power has been termed by some postcolonial studies scholars as "subaltern." All subaltern people had the agency to speak for themselves, but their concerns were generally unheeded by colonials. Settlers conceived the words and needs of the colonized in ways that allowed settlers to speak for 


\section{Introduction}

their putative subordinates. Margaret Jacobs has recently observed that "settler colonial theory helps to explain not only Indigenous histories but also aspects of slavery." It also helps us understand how the state came to intervene in the learning of colonials and the colonized. Settler colonial societies such as developed in Georgia and South Carolina were perhaps especially committed to such projects and can teach historians of other regions about the dynamics of learning and power in colonial settings. ${ }^{23}$

\section{A New History of Learning}

One aspect of modernity in education is the wider distribution of basic literacy. E. Jennifer Monaghan has shown how reading and writing were gradually merged, secularized, and made more widely available (especially reading) in the decades after 1750 . Another aspect of modernity in education is its role in state formation and defining citizenship, as Andy Green has argued. But modernity in education was about more than promoting skills that form a sovereign state's population; it also emphasized pointed exclusions that stigmatized people as ignorant or immoral. The incarceration of offenders or the expulsion of students from schools were among the more important punitive practices of modernity. The Lower South's elite tried to parlay their control of the resources of governments and private associations to limit both what Natives and Africans could learn and what significance that learning could have. They created schools to discipline how white people understood Britishness or U.S. citizenship. In doing so, they gradually built institutions that allowed elites to participate in shaping how nonelite people lived - not merely to decide who was still within the law and who was outlawed and subject to punishment or execution. In the early eighteenth century, the few education programs that elites extended to nonelites treated the poorest whites, Africans, and Natives similarly. Their education was mostly reading and religion, or what Monaghan calls the "ordinary road." A few decades after the American Revolution, however, the poorest whites had access to state-funded literacy and numeracy. Meanwhile, black people (free and enslaved) had been banned from reading or writing and Native people had been removed westward despite rapid and sustained institutional adjustments, among the Cherokee in particular, designed to demonstrate civilization. The significance of this divergence would be hard to exaggerate. It was a major development in the racialization of society in general, and of education specifically. ${ }^{24}$

While scholars have identified democratic republicanism, liberalism, modernization, industrialization, and urbanization as drivers of U.S. education development during the period of the Revolution and the Early Republic, these themes are more appropriate to analyses of northern education. Though the South was also capitalist, its capitalism was mostly in agriculture and slavery. The South was republican and liberal, but 
with institutions that protected and promoted slavery and settler expansion. Southern towns were generally smaller than those in the North, and industry was not as heavily developed. The South had a distinct pattern of innovation and modernization that featured sharp racialization of learning at the very moment when the democratic republic began to emphasize a literate citizenry. The regional pattern helps explain how and why the Lower South focused attention on innovative formal education development. Significant innovation was incited by slavery, settler colonialism, and plantation capitalism-not inhibited by it. ${ }^{25}$

Gradually, education policy and practice included poorer whites in order to give them skills that nonwhites were either forbidden or discouraged to acquire. Learning by nonwhites challenged the distinctions and power dynamics of colonial society, and whites eventually moved to thoroughgoing exclusion of nonwhites. Both the inclusion and the exclusion were in the service of contending versions of southern colonial modernity. Some wanted to convert and educate in ways that supported the overall structure of colonial society. These factions promoted institutional education interventions. Others wanted to suppress and discipline. These groups promoted policing and punishment institutions. Over time, education inclusion and exclusion arose from and reinforced a legal and ideological consensus on race: poorer whites would learn to read and write more often than nonwhites. Whites' ability to read, write, and cypher would be celebrated as progress, whereas such skills among black and Native people would rarely be celebrated and would sometimes be mocked, if not banned and punished. ${ }^{26}$ This inclusion/exclusion consensus was perhaps strongest in the South because of its unique combination of slavery and settler colonization, but its strong presence in the South probably bolstered such thinking and practice nationally.

Southern settler modernity arose from the management of people via the long-distance communication and trade networks that empire required. Native systems of communication came into contact with European networks in the seventeenth century. Colonials and Indigenous North Americans sometimes struggled over control of communication systems and information, as Matt Cohen has shown for New England and Alejandra Dubcovsky has shown for the early South. Geography, news, spirituality, and English-language competencies all became part of a struggle over empire during the eighteenth century. Maintaining transatlantic operations over time required practices and policies for the long-distance management of people. Printed and handwritten documents became a central technology of management. Literacy in English therefore became one of the most strategic skills anyone residing within English imperial claims might learn-essential for nonelite colonials and the colonized Natives and Africans as well. Correspondence within government and merchant networks, apprenticeship papers, agreements with Native Americans, and passes and free papers for the enslaved all used reading and writing skills. 


\section{Introduction}

The importance of printed, written, or spoken English within the English imperium was likely evident to almost any settler or colonized individual, and therefore colonial elites could not completely control who learned English, why, or how it was used by nonelites and non-Europeans. It is not surprising that some poorer whites, African Americans, and Native Americans aspired to learn to read and write English, given its power to affect their lives. Their ambitions to learn and use writing and reading should not automatically be understood as assimilation or as a precursor to the loss of culture. ${ }^{27}$

Inquiry into histories of learning within the colonial setting of the Lower South has implications for understanding Early America. ${ }^{28}$ Struggles over colonization and efforts to govern learning were a catalyst for race formation in American culture. A history of learning is about more than just survival and loss. It is a history of neither tradition nor "progress." It focuses neither on assimilation nor on conservation. Rather, it explains how hybrid ideas and practices challenged colonial expectations and examines how colonial elites responded with institutional interventions into learning. A history of learning is composed of the discourses that came to dominate for some and not others. It reveals reversals of powerful discourses and practices at the intimate level. It is a sociocultural history of a struggle between diverse people over colonial growth and of how that struggle yielded governments actively interested in controlling learning. Colonization was a process featuring "diverse peoples on frontiers [that] created new cultural forms." Colonization birthed a modern state quite different from what "modernization theory" proposes. Educational institutions, the advance of human knowledge, were not necessarily about progress, as modernization theory once proposed. Rather, the modernity that colonization birthed managed populations as races, and their learning was among the first aspects of their lives in which this new state form became interested. Colonials often saw this management as progress. Colonized Africans and Natives had other understandings and responses. ${ }^{29}$

The archival research supporting this argument ends with records from the 1820s. The Lower South has relatively few records for historians interested in the education of poorer and middling whites, African Americans, and Native Americans. Northern regions have better records-as do later periods in the South. Consequently, scholarship often focuses on places in the North or on the antebellum period in the South. Despite the archival challenges, it is important to study the earlier history in order to understand the basis for developments from the 1820s to the Civil War and beyond. The decades before the 1820s changed learning for poorer whites, African Americans, and Native Americans in significant ways. Before there were widespread black churches, there was the gradual realignment of African and African American spirituality, language, and politics. Before the "Five Civilized Tribes," there was a broad 
Cherokee and Creek engagement with white colonialism at the level of skills, habits, and attitudes regarding language, politics, and trade. Before the emergence of common schools for poor whites, there was a struggle for position within colonial society that included managing the learning of poorer whites. This book delves into the most difficult archives to show how these histories of learning were intertwined. The comparative approach reveals the origins of a pattern in U.S. history in which education is a widely acknowledged social value and yet persists as one of the most unequal and segregated parts of American life. ${ }^{30}$

\section{The Structure and Arrangement of This Book}

The arrangement of six chapters into two sections allows for multiple modes of reading. Readers less familiar with the regional history can get appropriate thematic introductions in Chapters 1 and 4 . These chapters summarize and synthesize existing scholarship, with some new primary research integrated into the discussion. The purpose of Chapters 1 and 4 is to establish the setting and context for the other chapters in each of the two parts. Part I focuses primarily on the early and middle eighteenth century, ending with the American Revolution. The second part narrates aspects of the Revolution in the region and carries the analysis forward to the edge of the antebellum period by terminating in events of the 1820 s.

Chapter 1 offers an overview or synthesis of the regional history of colonization. It draws mainly on scholarly literature to narrate major themes, placing the Lower South into the Atlantic world context. I emphasize how the colonial project produced a society of significant and powerful diversity as well as profitability. I then demonstrate the formation of a "colonial society" as I have defined it. Throughout, I integrate original research into an argument about how colonization affected the learning practices and policies of a wide variety of people, suffusing the character of everyday life.

Chapter 2 compares the rising interest in English speaking, reading, and writing among both enslaved Africans and Native Americans. Similar dynamics between Natives and Africans arise not from extensive contact between them, but rather from their extensive contact with colonial society. Over time, colonized people developed strategies of resistance and adaptation that involved mastering Anglo-European knowledge and redirecting these skills. Learning English was an accommodation to colonial society that also refused the full set of colonial demands. The English of Natives and African Americans articulated the needs of Native American and African American people. Their efforts to use learning created new cultural practices and skills.

Chapter 3 explores a variation of the same theme. Poorer or middling whites positioned themselves against "savage" and "barbaric" colonized people for complex reasons of status in colonial society. Learning became 
a struggle for respect and power, and as such it was increasingly a concern of nonelite whites. A central claim here is that poorer and middling whites became interested in formal schooling out of an interest in staking claims to civility or civilization. A centerpiece of the argument is a comparative analysis of the use of "civilization" and similar rhetoric. Elites often wanted or needed to include poorer or middling whites among colonial society's defenders, while Africans and Native Americans were less often seen in this way. Poorer whites gained a special status as a uniquely important group to reform and educate in ways rarely contemplated for Africans and Native Americans. Before the American Revolution, South Carolina produced its first bill for publicly supported education for nonelite whites across the colony —an important harbinger of post-Revolutionary efforts to create public schools for all whites.

Part II covers the 1780s and subsequent decades. It shows how colonial dynamics of learning weathered the American Revolution and the democratic politics of the South Carolina and Georgia republics. Chapter 4 outlines recent perspectives on the American Revolution in order to build upon them. The Revolution in the South has come to be best understood as a "triagonal war" between colonial whites, British regulars and their Loyalists, and the enslaved. One might add to this schema the Indigenous peoples who sided with Britain or attempted neutrality. The war for independence was a movement that elites were forced into by unruly whites, restive slaves, and persistent British assertions of authority. I contribute to this argument by contending that rebellion against whites by enslaved people was forward-looking, in that it was culturally generative. Defeat for the enslaved who remained in the Lower South after the war, and for Native people, set the stage for other options, such as religious conversions and "civilization." White responses to these developments were also generative of new initiatives for poor white schooling. ${ }^{31}$ Chapters 5 and 6 elaborate on this argument through analysis of local historical records, some of which have not been previously worked with by professional historians. The chapters demonstrate that important elements of colonial society persisted after the Revolution and shaped the legacy of independence with regard to policies and practices governing the learning of nonelite people.

The concluding chapter is a "coda" bringing the various themes of the book together in a summative statement. It reflects on how "colonial society" underwent a gradual transformation into a racist nationstate during the nineteenth century. The American Revolution itself was important in this transformation. The expansion of both plantation capitalism and U.S. colonization of the Old Southwest (east of the Mississippi) were major factors. That the African-born proportion of the enslaved population declined after the 1790s and the legal "salt-water" slave trade was closed after 1807 were also significant. Lastly, the transformation of the Lower South from an acutely colonial to a sharply racist society also occurred in conjunction with the U.S. assault upon 
the last large and autonomous Native peoples, coercively moving most of their tribal leaderships and governments westward in the 1820s and 1830s.

As a result of these changes, the culture of colonial encounter no longer suffused everyday life. Southerners eventually asserted an identity rooted in a curious combination of nostalgia and amnesia about the colonial process of conquest and about the colonized peoples, Native and African, who their society had marginalized and exploited to produce itself. Whites, on land their families had sometimes colonized just a generation or two earlier, regarded themselves as Native. This was the unequal legacy of the colonial dynamics between settlers, African-born slaves, and Native Americans. In this more deeply racialized society where whites protected an unprecedented supremacy, Native communities that had evaded removal in the hills of the Backcountry continued to speak Native languages, but their effect on the overall tone of daily life was not strong. Gullah and other African American communities continued to live in ways that were rooted in African cultures, but subsequent generations born in America continued to adapt through hybrid learning in ways that represented a different path from that of cousins across the Atlantic. Colonization had once driven efforts to shape how people learned. By the 1850s, proslavery Southerners conceived of the racial order that they inherited and sharpened as the pinnacle of progress. They racialized learning so that in the late decades of slavery, whites-both men and women, richer and poorer-had unprecedented access to formal instruction while the enslaved, free black people, and marginalized Native communities were either prohibited or inhibited by statute or practice from similar pursuits. This racialization of learning in a powerful region was among colonization's most important legacies for the country as a whole. It drove education segregation and shaped policy and culture for generations to come. The significance of that legacy for the history of the United States would be difficult to overstate.

\section{Notes}

1. Francis LeJau, The Carolina Chronicle of Francis Le Jau, 1706-1717, Frank Klingberg, ed. (Berkeley, CA, 1956), 70.

2. The New Pilgrim's Progress, or, the Pious Indian Convert . . . (London, 1748), 6. Richard Vines, A Treatise of the Institution . . of the Lord's Supper (London, 1677), 386-387. The "spider" and "rose" metaphor was an old trope with Classic origins. Francis Beaumont and John Fletcher used it in their drama "Triumph of Honor," see: Robert William Dent, Proverbial Language in English Drama Exclusive of Shakespeare, 1495-1616 (Berkeley, 1984), 201. I am indebted to an anonymous reviewer for the identification of the sources of this metaphor.

3. LeJau, Carolina Chronicle, 70.

4. Carl Mauelshagen and Gerald H. Davis, eds. and trans., Partners in the Lord's Work: The Diary of the Two Moravian Missionaries in the Creek Indian Country, 1807-1813 (Atlanta, 1969), 39, 52 (Negro Phil). 
5. Glen Sean Coulthard has recently brought this perspective to Native American studies. Coulthard has argued, using Frantz Fanon's Black Skin, White Masks, that colonization affected colonized people both objectively and subjectively. Glen Sean Coulthard, Red Skin, White Masks: Rejecting the Colonial Politics of Recognition (Minneapolis, MN, 2014), passim. Amie Cesaire, Discourse on Colonialism (New York and London: Monthly Review Press, 1972), 177 (quote). See also David Brion Davis, The Problem of Slavery in the Age of Revolution: 1770-1823 (New York, 1975), 81-84.

6. See Michel Foucault on biopower and biopolitics in The History of Sexuality: Volume 1, an Introduction, Robert Hurley, trans. (New York, 1978), 135-145. In the recent historiography of the South, this argument complements that of Jessica Stern, The Lives in Objects: Native Americans, British Colonists, and Cultures of Labor and Exchange in the Colonial Southeast (Chapel Hill, 2016), 12-13. In fact, what Stern describes as the development over time of a generative need and achievement of "greater cross-cultural understanding" to facilitate exchange (p. 50) could also be termed learning.

7. Marcus Rediker and Peter Linebaugh, The Many-Headed Hydra: Sailors, Slaves, Commoners, and the Hidden History of the Revolutionary Atlantic (Boston, 2000), 332-333. Homi K. Bhabha, "Signs Taken for Wonders," The Location of Culture (New York, 1994), 145-176.

8. On race and exclusion in the American Revolution, see Robert Parkinson, The Common Cause: Creating Race and Nation in the American Revolution (Chapel Hill, 2016), passim. Identifying inclusion/exclusion patterns as a force in the production of modern institutions of education positions my argument against modernization theory and interpretations of education development that rely upon it. Modernization theory has been critiqued as Eurocentric, and yet it arguably continues to influence historiography of literacy and education in early America. The examples of inclusion/exclusion explored in this book do not represent a systemic, modern process. Rather, the learning and education developments discussed in this book are analyzed as events within relations of power that were more dynamic, unsettled, and contested than systematicity suggests. At its heart, this approach to modernity draws upon Michel Foucault's notion of governmentality and biopolitics, as well as the work of two of his most influential interpreters: Ann Laura Stoler and Giorgio Agamben. Stoler has focused on intimate incorporations of colonized people into imperial relations of power, see: "Intimidations of Empire: Predicaments of the Tactile and the Unseen," in Haunted by Empire: Geographies of Intimacy in North American History (Durham, NC, 2007) and Race and the Education of Desire (New York, 1997). Also of significance for my work in this book, Giorgio Agamben's interpretations of biopolitics have focused more on the exclusionary dynamics of power, see: State of Exception (Chicago, 2005) and Homo Sacer (Stanford, CA, 1998). Agamben's work focuses heavily on exclusions. See also: John Willinsky, Learning to Divide the World: Education at Empire's End (Minneapolis: University of Minneapolis Press, 1998), passim. Acts of the General Assembly of the State of Georgia . . 1829 (Milledgeville: Camak \& Ragland, 1830), 168, 171, 175. For a classic critique of Modernization Theory, see Andre Gunder Frank, Latin America: Underdevelopment or Revolution (New York, 1969).

9. I ground a definition of colonial society in the literature on settler colonialism as well as three aspects of the Lower South's specific historical context. First, I expand Philip D. Morgan's definition of a slave society (as opposed to a society with slaves) to argue that the effort to manage the bodies and will of the enslaved suffused cultural, social, and political life. And the enslaved 
population was substantially composed of recent African arrivals through the end of the eighteenth century. Second, Georgia and South Carolina were deeply and actively engaged in the acquisition and settlement of millions of acres of Creek, Cherokee, and Catawba land throughout the period under study. Therefore, daily life in Georgia and South Carolina was suffused by colonial processes and practices of land settlement. Third, such colonial ubiquity will change colonials themselves. Both colonized and colonial communities and individuals will learn and change subtly and traceably. In other times and contexts, perhaps one might argue that the changes were not even partly due to colonization. However, political, cultural, and economic change in the Lower South was seldom separable from colonial aims and was sometimes dominated by them. This is a definition of the scope and influence of settler colonial society that is both historically contingent and geographically specific, and therefore susceptible to historical study. Ania Loomba, Colonialism/Postcolonialism (New York: Routledge, 2005), 7-11; Patrick Wolfe, "Land, Labor, and Difference: Elementary Structures of Race," AHR 106 (2001): 868 (defining settler colonialism as elimination and contrasting/comparing it to slave societies).

10. See Joshua Piker, "Lying Together: The Imperial Implications of CrossCultural Untruths," AHR (2011): 966-970; Sven Beckert, Empire of Cotton: A Global History (New York, 2015), xv and passim. See also Walter Johnson, Soul by Soul: Life inside the Antebellum Slave Market (Cambridge, 1999) and Stephane Smallwood, Saltwater Slavery: A Middle Passage from Africa to American Diaspora (Cambridge, 2007), 36.

11. Bhabha, "Signs Taken for Wonders," 153 ("agonistic" proposed as the impetus behind hybridity, rather than a Manichean "antagonism"). My discussion of comparison follows, especially, several works: Stoler, "Intimidations of Empire," 1-22; Patrick Wolfe, Traces of History: Elementary Structures of Race (London, 2016), 1-30; Julian Go, Patterns of Empire: Britain and the United States Compared (New York, 2011), 33-66 (lays out the relationship between colonization, empire, and race in comparative perspectives on Native Americans, Africans, Australia, and Palestine); Jane Burbank and Frederick Cooper, "Oceanic Economies and Colonial Societies: Europe, Asia, America," in Empires in World History: Power and the Politics of Difference (Princeton, 2010), 149-164; John Wood Sweet, Bodies Politic: Negotiating Race in the American North, 1730-1830 (Baltimore, 2003); and Amy Kaplan, Cultures of Empire (New York 1993). See also Allan Greer, "Commons and Enclosure in the Colonization of North America," AHR 117, no. 2 (April, 2012), 365-386; Walter Hixson, American Settler Colonialism: A History (New York, 2013); and Ed White and Michael J. Drexler, “The Theory Gap," American Literary History 22, no. 2 (2010): 480-494 at 491-492 (quotes).

12. Bhabha, "Signs Taken for Wonders," 145-176. For influential books in colonial/postcolonial studies that have influenced this work's analysis of historic colonization see: Malini Johar Schueler and Ed Watts "Introduction," in Malini Johar Scheuler and Ed Watts, eds., Messy Beginnings: Postcoloniality and Early American Studies (New Brunswick, NJ, 2003), 1-28; Christine Daniels and Michael C. Kennedy, eds., Negotiated Empires: Centers and Peripheries in the Americas 1500-1820 (London, 2002); Michael Warner "What's Colonial about Colonial America," in Robert Blair St. George ed., Possible Pasts: Becoming Colonial in Early America (Ithaca, NY, 2000), 49-70; Nicholas Thomas, Colonialism's Culture: Anthropology, Travel, and Government (Princeton, 1994); Stoler, Race and the Education of Desire; Amy Kaplan, "Left alone with America," in Kaplan and Donald E. Pease, 
eds., Cultures of United States Imperialism (Durham, NC, 1993), 16; Marie Louise Pratt's Imperial Eyes: Travel Writing and Transculturation (New York, 1992); Andrew R. L. Cayton and Fredrika Teute, eds., "Introduction: On the Connection of Frontiers," in Contact Points: American Frontiers from the Mohawk Valley to the Mississippi, 1750-1830 (Chapel Hill, NC, 1998), 1-15; Gyan Prakash, "Subaltern Studies as Postcolonial Criticism," in Catherine Hall, ed., Cultures of Empire, A Reader: Colonizers in Britain and the Empire in the Nineteenth and Twentieth Centuries (New York, 2000), 120-136, esp 124-125, 133-134.

13. Wolfe, Traces of History, 70.

14. Governing learning in this way is a form of modernity Foucault called biopolitics: History of Sexuality, Volume 1; and Stoler, Haunted by Empire, passim, and Agamben, State of Exception, passim.

15. The nature of the archives on Early America and Africans or Native Americans is such that almost any study of slaves or Native Americans is comparative in some sense, since the records are almost always predominantly, if not exclusively, produced by white colonials. Some works have tried to compare intertwined histories explicitly. A small sampling would include: Tiya Miles, Ties that Bind: The Story of an Afro-Cherokee Family in Slavery and Freedom (Berkeley, 2006); Mechal Sobel, The World They Made Together: Black and White Values in Eighteenth-Century Virginia (Princeton, NJ, 1987); Claudio Saunt, "The English has Now a Mind to Makes Slaves of Them All': Creeks, Seminoles, and the Problem of Slavery," Confounding the Color Line: The Indian-Black Experience in North America (2002), 64, n.5, 7, 8; Patrick N. Minges, "Red, White, and Black in the Old South," in Patrick N. Minges, ed., Slavery in the Cherokee Nation (London, 2003), 5-28; Theda Perdue, Slavery and the Evolution of Cherokee Society, 1540-1866 (Knoxville, TN, 1979); Timothy Lockley, Lines in the Sand: Race and Class in Lowcountry Georgia, 1750-1860 (Athens, GA, 2001); and Daniel F. Littlefield, Africans \& Creeks: from the Colonial Period to the Civil War (Westport, CT, 1979).

16. Edward Countryman, "Indians, the Colonial Order, and the Social Significance of the American Revolution," William and Mary Quarterly, 3rd Ser., 53, no. 2 (1996): 354; St. George, "Introduction," in St. George, ed., Possible Pasts: Becoming Colonial in Early America (Chapel Hill, NC, 2000), 4-7.

17. John K. Thornton, "African Dimensions of the Stono Rebellion," AHR 96 (1991): 1101-1113; Peter Wood, Black Majority: Negroes in Colonial South Carolina from 1670 Through the Stono Rebellion (New York, 1974), 323324; John Marrant, "Narrative," in Adam Potkay and Sandra Burr, eds., Black Atlantic Writers of the Eighteenth Century (New York, 1995), 91-92; Phillis Wheatley, Poems of Phillis Wheatley: A Native African and a Slave (Bedford, MA, 1995 [1838]), 12.

18. Stoler, "Intimidations of Empire," 2 (quote). A method of this study has been a comparison of scholarship from diverse fields. Among many interests that Native American studies and African American studies scholars have shared with subaltern studies or postcolonial studies has been an interest in recovering the voices of colonized peoples, the negotiated relations of power, and the cultural changes and compromises that resulted from colonization. See: Eric Hinderaker, Elusive Empires: Constructing Colonialism in the Obio Valley, 1673-1800 (Cambridge, 1997), xi; Daniels and Kennedy, eds., Negotiated Empires; Gregory Castle, "Resistance and Complicity in Postcolonial Studies," in Gregory Castle, ed., Postcolonial Discourses (Oxford, 2001), xix; Gayatri Spivak, "Can the Subaltern Speak?" in Cary Nelson and Larry Grossberg, eds., Marxism and the Interpretation of Culture (Chicago, 1988), 271-313. 
19. Ira Berlin, Many Thousands Gone: The First Two Centuries of Slavery in North America (Cambridge, 1998); Sobel, World They Made Together; John K. Thornton, Africa and Africans in the Making of the Atlantic World, 14001800 (Cambridge, 1998), 207; Claire Robertson, "Africa into the Americas? Slavery and Women, the Family, and the Gender Division of Labor," in David Barry Gaspar and Darlene Clark Hine, eds., More than Chattel: Black Women and Slavery in the Americas (Bloomington, 1996), 3-40; Jennifer L. Morgan, Laboring Women: Reproduction and Gender in New World Slavery (Philadelphia, 2004), 167. Daniel C. Littlefield, Rice and Slaves: Ethnicity and the Slave Trade in Colonial South Carolina (Baton Rouge, Louisiana, 1981), 125; Sandra Greene, Gender, Ethnicity, and Social Change on the Upper Slave Coast (Portsmouth, New Hampshire: Heinemann, 1997), 4-5, $20-47$. Michael P. Johnson and James L. Roark, "'A Middle Ground:' Free Mulattoes and the Friendly Moralist Society of Antebellum Charleston," Southern Studies 21 (Fall 1983): 246-265; Robert L. Harris Jr., "Early Black Benevolent Societies, 1780-1830," The Massachusetts Review (1979): 603-625; Mary Carroll Johansen, "'Intelligence, though Overlooked:' Education for Black Women in the Upper South, 1800-1840," Maryland Historical Magazine 93, no. 4 (1998): 443-465; James B. Lawrence, "Religious Education of the Negro in the Colony of Georgia," GHQ 14 (March 1930): 41-57. Douglas B. Chambers, " 'My Own Nation': Igbo Exiles in the Diaspora” and Philip D. Morgan, "The Cultural Implications of the Atlantic Slave Trade: African Regional Origins, American Destinations, and the New World," in David Eltis and David Richardson, eds., Routes to Slavery: Direction, Ethnicity, and Mortality in the Transatlantic Slave Trade (London, 1997), 72-97 and 122145; Michael Gomez, Exchanging our Country Marks: The Transformation of African Identities in the Colonial and Antebellum South (Chapel Hill, NC, 1998); Paul E. Lovejoy, Transformations in Slavery: A History of Slavery in Africa, Second Edition (Cambridge, 2000). Peter Wood, Black Majority. Littlefield, Rice and Slaves; Elizabeth Fox-Genovese, Within the Plantation Household: Black and White Women of the Old South (Chapel Hill, NC, 1988); Margaret Creel, A Peculiar People: Slave Religion and CommunityCulture among the Gullahs (New York, 1988).

20. Joshua Piker, The Four Deaths of Acorn Whistler: Telling Stories in Colonial America (London, 2013), 200-201 and passim; Claudio Saunt, A New Order of Things: Property, Power, and the Transformation of the Creek Indians, 1733-1816 (Cambridge, 1999), 187 \& chapter 8 "The Power of Writing," 186-204; Theda Perdue, Cherokee Women: Gender and Culture Change, 1700-1835 (Lincoln, NE, 1998) and Slavery and the Evolution of Cherokee Society, 1540-1866; Steven C. Hahn, The Invention of the Creek Nation, 1670-1763 (Lincoln, NB, 2004); Robbie Ethridge, Creek Country: The Creek Indians and Their World (Chapel Hill, NC, 2003); Joshua Piker, Okfuskee: A Creek Indian Town in Colonial America (Cambridge, 2004); Andrew K. Frank, Creeks and Southerners: Biculturalism on the Early American Frontier (Lincoln, 2005). See also Nancy Shoemaker, ed., Negotiators of Change: Historical Perspectives on Native American Women (New York, 1995).

21. Stephanie M. H. Camp, Closer to Freedom: Enslaved Women and Everyday Resistance in the Plantation South (Chapel Hill, NC, 2004); Kathleen M. Brown, Good Wives, Nasty Wenches, Anxious Patriarchs (Chapel Hill, NC, 1996); Kirsten Fischer, Suspect Relations: Sex, Race, and Resistance in Colonial North Carolina (Ithaca, 2002). See also Fox-Genovese, Within the Plantation Household.

22. Lockley, Lines in the Sand, xiii; J. William Harris, Plain Folk and Gentry in a Slave Society: White Liberty and Black Slavery in Augusta's Hinterlands 
(Baton Rouge, 1998). Lacy Ford, "Popular Ideology of the South's Plainfolk," in Samuel C. Hyde, ed., Plain Folk of the South Revisited (Baton Rouge, 1997), 205-227; Stephanie McCurry, Masters of Small Worlds: Yeoman Households, Gender Relations, and the Political Culture of the Antebellum South Carolina Household (New York, 1995).

23. For recent discussions of settler colonialism, the state, race, and the colonized, in which this book's interpretation participates, see: Jacobs, "Seeing Like a Settler Colonial State," Modern American History 1, no. 2 (July 2018): 257270; Evelyn Nakano Glenn, "Settler Colonialism as Structure: A Framework for Comparative Studies of U.S. Race and Gender Formation," Sociology of Race and Ethnicity 1 (2015): 54-74; Aziz Rana, The Two Faces of American Freedom (Cambridge, 2014); Hixson, American Settler Colonialism; Lisa Ford, Settler Sovereignty: Jurisdiction and Indigenous People in America and Australia, 1788-1836 (Cambridge, 2011); Lorenzo Veracini, "Telling the End of the Settler Colonial History," in F. Bateman and L. Pilkington, eds., Studies in Settler Colonialism: Politics, Identity, and Culture (New York, 2011), 204-218; Lorenzo Veracini, Settler Colonialism: A Theoretical Overview (New York, 2010); Frederick E. Hoxie, "Retrieving the Red Continent: Settler colonialism and the history of American Indians in the US," Ethnic and Racial Studies 31, no. 6 (2008): 1153-1167.

On the voice of the subaltern, see: Ann Laura Stoler, "Tense and Tender Ties: The Politics of Comparison in North American History and (Post) Colonial Studies" and "Matters of Intimacy as Matters of State: A Response" from the forum "Empires and Intimacies: Lessons from (Post) Colonial Studies," The Journal of American History 88, no. 3 (2001): 829-865 and 893-896. Some of Stoler's themes also seem to draw from Gayatri Spivak in her essay "Can the Subaltern Speak? Speculations on Widow-Sacrifice," Wedge 7/8 (Winter/ Spring 1985): 120-130. See also James C. Scott, Domination and the Arts of Resistance: Hidden Transcripts (Princeton, 1992).

24. Andy Green, Education and State Formation: Europe, East Asia and the USA (London, 2013), 1-10, 170-175. E. Jennifer Monaghan, Learning to Read and Write in Colonial America: Literacy Instruction and Acquisition in Cultural Context (Amherst, MA, 2005), 6 for the date of 1750, which was also identified by Thomas Woody in the narrower field of women's education: Thomas Woody, History of Women's Education in the United States, 2 vols (New York, 1929), vol. 1, 301-302, 229-233 as cited by Nash, "Rethinking," 173 (n.6). My argument further confirms the importance of the middle eighteenth century.

25. Lawrence A. Cremin, American Education: The National Experience, 17831876 (New York, 1980); Carl Kaestle, Pillars of the Republic: Common Schools and American Society, 1780-1860 (New York, 1983), 3-4.

26. The link between politics, race, and social projecting or public institutions has been a theme in much of the scholarship on the Lower South in recent decades. For examples: Rachel N. Klein, Unification of a Slave State: the Rise of the Planter Class in the South Carolina Backcountry, 1760-1808 (Chapel Hill, 1990). See also Rebecca Starr, A School for Politics: Commercial Lobbying and Political Culture in Early South Carolina (Baltimore, 1998); Lacy Ford, The Origins of Southern Radicalism: The South Carolina Upcountry, 1800-1860 (Oxford, 1988).

27. As Michael Warner has pointed out in "What's Colonial about Colonial America?" in Possible Pasts, 67 (\& n.44), scholars have long looked to print as an important vehicle for building empire: Warner cites Harold Innis, Empire and Communication (Oxford, 1959), among other works. Saunt, A New Order of Things, chapter 8. Alejandra Dubcovsky, Informed Power: Communication in the Early American South (Cambridge, 2016), 4-5, and Matt Cohen, 
The Networked Wilderness: Communicating in Early New England (Minneapolis, 2008), 21, 66. See also: Andrew Newman, On Records: Delaware Indians, Colonists, and the Media of History and Memory (Lincoln, NE, 2012) and Hilary E. Wyss, Writing Indians: Literacy, Christianity, and Native Community in Early America (Amherst: University of Massachusetts Press, 2002).

28. Willinsky, Learning to Divide the World.

29. See also Samuel Bowles and Herbert Gintis, Schooling in Capitalist America (New York: Basic Books, 1976). The "Bowles and Gintis" thesis that schools reproduce economic inequality received significant criticism at the time, but the thesis and its evidence influenced a generation of critical scholars who have elaborated and revised it. Broadening the perspective on power beyond class, while still including it, is R. A. Morrow, "Education and the Reproduction of Class, Gender, and Race: Responding to the Postmodern Challenge," Educational Theory 34 (1994): 43-61. Cayton and Teute, Contact Points, 5. Foucauldian methods have rarely been applied by new Indian historians or African American studies scholars. For an example see: L. Stewart, "Louisiana Subjects: Power, Space, and the Slave Body," Ecumene 2, no. 3 (1995): 227-245. An old distinction, sometimes a debate, between macro and micro histories of empire continues. See for example John Darwin, The Empire Project: The Rise and Fall of the British World System, 1830-1970 (Cambridge, 2011), Maya Jasanoff, Edge of Empire: Conquest and Collecting in the East (New York, 2007), and Catherine Hall, Civilising Subjects: Metropole and Colony in the English Imagination, 1830-1867 (Chicago, 2002).

30. Hillary E. Wyss, English Letters and Indian Literacies: Reading Writing, and New England Missionary Schools (Philadelphia, 2012), 6-7. Wyss shows how "writerly Indians" in New England could use literacy to manage their own sovereignty claims and challenge the goals of missionaries.

31. Eugene Genovese, From Rebellion to Revolution: Afro-American Slave Revolts in the Making of the Modern World (Baton Rouge, Louisiana, 1992 [1979]), 3, 11-12. Genovese outlined a controversial distinction between backward- and forward-looking perspectives by the enslaved. Carolyn Fick, Making Haiti and Geggus, Haitian Revolutionary Studies (Knoxville, 1990), 65 explicitly rejects that interpretation.

\section{Bibliography}

Acts of the General Assembly of the State of Georgia . . 1829. Milledgeville: Camak \& Ragland, 1830.

Agamben, Giorgio. Homo Sacer: Sovereign Power and Bare Life. Stanford, CA: Stanford University Press, 1998.

- State of Exception. Chicago: University of Chicago Press, 2005.

Beckert, Sven. The Empire of Cotton: A Global History. New York: Alfred A. Knopf, 2015.

Berlin, Ira. Many Thousands Gone: The First Two Centuries of Slavery in North America. Cambridge, MA: Belknap Press of Harvard University Press, 1998.

Bhabha, Homi K. "Signs Taken for Wonders: Questions of Ambivalence and Authority under a Tree Outside Delhi, May 1817." Critical Inquiry 12, no. 1 (1985): 144-165.

- The Location of Culture. New York: Routledge, 1994.

Braund, Kathryn E. Holland, ed. Confounding the Color Line: The Indian-Black Experience in North America. University of Nebraska Press, 2002. 


\section{Introduction}

Brown, Kathleen M. Good Wives, Nasty Wenches, and Anxious Patriarchs: Gender, Race, and Power in Colonial Virginia. Chapel Hill, NC: Published for Institute of Early American History and Culture by University of North Carolina Press, 1996.

Burbank, Jane, and Frederick Cooper. Empires in World History: Power and the Politics of Difference. Princeton, NJ: Princeton University Press, 2010.

Camp, Stephanie M. H. Closer to Freedom: Enslaved Women and Everyday Resistance in the Plantation South. Chapel Hill, NC: University of North Carolina Press, 2004.

Castle, Gregory. Postcolonial Discourses: An Anthology. Oxford: Blackwell Publishers, 2001.

Césaire, Aimé. Discourse on Colonialism. New York and London: Monthly Review Press, 1972.

Cohen, Matt. The Networked Wilderness: Communicating in Early New England. Minneapolis: University of Minnesota Press, 2008.

Coulthard, Glen Sean. Red Skin, White Masks: Rejecting the Colonial Politics of Recognition. Minneapolis: University of Minnesota Press, 2014.

Countryman, Edward. "Indians, the Colonial Order, and the Social Significance of the American Revolution." The William and Mary Quarterly 53, no. 2 (1996): 342-362.

Creel, Margaret Washington. A Peculiar People: Slave Religion and CommunityCulture Among the Gullahs. New York: New York University, 1988.

Cremin, Lawrence A. The National Experience: 1783-1876. New York: Harper \& Row, 1980.

Daniels, Christine, and Michael C. Kennedy, eds. Negotiated Empires: Centers and Peripheries in the Americas 1500-1820. London: Routledge, 2002.

Darwin, John. The Empire Project: The Rise and Fall of the British WorldSystem, 1830-1970. Cambridge: Cambridge University Press, 2011.

Davis, David Brion. The Problem of Slavery in the Age of Revolution, 17701823. New York: Cornell University Press, 1975.

Dent, Robert William. Proverbial Language in English Drama Exclusive of Shakespeare, 1495-1616: An Index. Berkeley: University of California Press, 1984.

Drexler, Michael J., and Ed White. “The Theory Gap.” American Literary History 22, no. 2 (2010): 480-494.

Dubcovsky, Alejandra. Informed Power: Communication in the Early American South. Cambridge: Harvard University Press, 2016.

Ethridge, Robbie. Creek Country: The Creek Indians and their World. Chapel Hill, NC: University of North Carolina Press, 2003.

Fick, Carolyn E. Making Haiti: Saint Domingue Revolution from Below. Knoxville: University of Tennessee Press, 1990.

Fischer, Kirsten. Suspect Relations: Sex, Race, and Resistance in Colonial North Carolina. Ithaca, NY: Cornell University Press, 2001.

Ford, Lacy K. Origins of Southern Radicalism: The South Carolina Upcountry, 1800-1860. New York: Oxford University Press, 1988.

Ford, Lisa. Settler Sovereignty: Jurisdiction and Indigenous People in America and Australia, 1788-1836. Cambridge: Harvard University Press, 2011.

Foucault, Michel. The History of Sexuality: Volume 1, an Introduction. Robert Hurley, trans. New York: Pantheon, 1978. 
Fox-Genovese, Elizabeth. Within the Plantation Household: Black and White Women of the Old South. Chapel Hill, NC: University of North Carolina Press, 1988.

Frank, Andre Gunder. Latin America: Underdevelopment or Revolution. Essays on the Development of Underdevelopment and the Immediate Enemy. New York: Monthly Review Press, 1969.

Frank, Andrew. Creeks \& Southerners: Biculturalism on the Early American Frontier. Lincoln, NE: University of Nebraska Press, 2005.

Gaspar, David Barry, and Darlene Clark Hine, eds. More than Chattel: Black Women and Slavery in the Americas. Bloomington: Indiana University Press, 1996.

Geggus, David Patrick. Haitian Revolutionary Studies. Bloomington: Indiana University Press, 2002.

Genovese, Eugene. From Rebellion to Revolution: Afro-American Slave Revolts in the Making of the Modern World. Baton Rouge: Louisiana State University Press, 1979.

Glenn, Evelyn Nakano. "Settler Colonialism as Structure: A Framework for Comparative Studies of U.S. Race and Gender Formation.” Sociology of Race and Ethnicity 1 (2015): 54-74.

Go, Julian. Patterns of Empire: The British and American Empires, 1688 to the Present. Cambridge: Cambridge University Press, 2011.

Gomez, Michael. Exchanging Our Country Marks: The Transformation of African Identities in the Colonial and Antebellum South. Chapel Hill, NC: University of North Carolina Press, 1998.

Green, Andy. Education and State Formation: Europe, East Asia and the USA. Houndmills, Basingstoke, Hampshire: Palgrave Macmillan, 2013.

Greer, Allan. "Commons and Enclosure in the Colonization of North America." The American Historical Review 117, no. 2 (April 1, 2012): 365-386.

Hahn, Steven C. The Invention of the Creek Nation, 1670-1763. Lincoln, NE: University of Nebraska Press, 2004.

Hall, Cathrine, ed. Cultures of Empire: Colonizers in Britain and the Empire in the Nineteenth and Twentieth Centuries, A Reader. New York: Routledge, 2000.

Hall, Catherine. Civilising Subjects: Metropole and Colony in the English Imagination, 1830-1867. Chicago: University of Chicago Press, 2002.

Harris, J. William. Plain folk and Gentry in a Slave Society: White Liberty and Black Slavery in Augusta's Hinterlands. Baton Rouge: Louisiana State University Press, 1998.

Harris, Robert L. Jr. "Early Black Benevolent Societies, 1780-1830." The Massachusetts Review (1979): 603-625.

Hinderaker, Eric. Elusive Empires: Constructing Colonialism in the Obio Valley, 1673-1800. Cambridge: Cambridge University Press, 1997.

Hixson, Walter L. American Settler Colonialism: A History. New York: Palgrave Macmillan US Imprint: Palgrave Macmillan, 2013.

Hoxie, Frederick E. "Retrieving the Red Continent: Settler Colonialism and the History of American Indians in the Us." Ethnic and Racial Studies 31, no. 6 (2008): 1153-1167.

Hyde, Samuel C. Plain Folk of the South Revisited. Baton Rouge: Louisiana State University Press, 1997. 


\section{Introduction}

Jacobs, Margaret D. "Seeing Like a Settler Colonial State." Modern American History 1, no. 2 (2018): 257-270.

Jasanoff, Maya. Edge of Empire: Lives, Culture, and Conquest in the East, 1750-1850. New York: Vintage Books, 2007.

Johansen, Mary Carroll. “'Intelligence, Though Overlooked': Education for Black Women in the Upper South, 1800-1840.” Maryland Historical Magazine 93 (1998): 443-465.

Johnson, Michael P., and James L. Roark. “'A Middle Ground': Free Mulattoes and the Friendly Moralist Society of Antebellum Charleston." Southern Studies 21 (Fall 1983): 246-265.

Johnson, Walter. Soul by Soul: Life Inside the Antebellum Slave Market. Cambridge: Harvard University Press, 1999.

Kaplan, Amy, and Donald E. Pease. Cultures of United States Imperialism. Durham: Duke University Press, 1993.

Klein, Rachel. Unification of a Slave State: The Rise of the Planter Class in the South Carolina Backcountry, 1760-1808. Chapel Hill, NC: University of North Carolina Press, 1990.

Lawrence, James B. "Religious Education of the Negro in the Colony of Georgia.” GHQ 14 (March 1930): 41-57.

Le Jau, F., and F. J. Klingberg (Frank Joseph). The Carolina Chronicle of Dr. Francis Le Jau, 1706-1717. Berkeley: University of California Press, 1956.

Linebaugh, Peter, and Marcus Rediker. The Many-Headed Hydra: Sailors, Slaves, Commoners, and the Hidden History of the Revolutionary Atlantic. Boston: Beacon Press, 2000.

Littlefield, Daniel C. Rice and Slaves: Ethnicity and the Slave Trade in Colonial South Carolina. Urbana: University of Illinois Press, 1981.

Littlefield, Daniel F. Africans and Creeks: From the Colonial Period to the Civil War. Westport, CT: Greenwood Press, 1979.

Lockley, Timothy. Lines in the Sand: Race and Class in Lowcountry Georgia, 1750-1860. Athens, GA: University of Georgia Press, 2001.

Loomba, Ania. Colonialism/Postcolonialism. London: Routledge, 2005.

Lovejoy, Paul E. Transformations in Slavery: A History of Slavery in Africa. 2nd Edition. Cambridge: Cambridge University Press, 2000.

Marrant, John. “A Narrative of the Lord's Wonderful Dealings with John Marrant, A Black." 1785. In Adam Potkay and Sandra Burr, eds. Black Atlantic Writers of the Eighteenth Century: Living the New Exodus in England and the Americas. New York: Palgrave Macmillan, 1995.

Mauelshagen, Carl, and Gerald H. Davis, eds. and trans. Partners in the Lord's Work: The Diary of the Two Moravian Missionaries in the Creek Indian Country, 1807-1813. Atlanta: Georgia State College, 1969.

McCurry, Stephanie. Masters of Small Worlds: Gender Relations, Yeoman Households and the Political Culture of the South Carolina Lowcountry. Oxford: Oxford University Press, 1995.

Miles, Tiya. Ties That Bind: The Story of an Afro-Cherokee Family in Slavery and Freedom. Berkeley: University of California Press, 2006.

Minges, Patrick N. Slavery in the Cherokee Nation: The Keetoowah Society and the Defining of a People, 1855-1867. London: Routledge, 2003.

Monaghan, E. Jennifer. Learning to Read and Write in Colonial America. Amherst: University of Massachusetts Press, 2005. 
Morgan, Jennifer L. Laboring Women: Reproduction and Gender in New World Slavery. Philadelphia: University of Pennsylvania Press, 2004.

Morgan, Philip D. "The Cultural Implications of the Atlantic Slave Trade: African Regional Origins, American Destinations, and the New World.” In David Eltis and David Richardson, eds. Routes to Slavery: Direction, Ethnicity, and Mortality in the Transatlantic Slave Trade. London: Routledge, 2013, 122-145.

Morrow, Raymond A., and Carlos Alberto Torres. "Education and the Reproduction of Class, Gender, and Race: Responding to the Postmodern Challenge." Educational Theory 44, no. 1 (1994): 43-61.

Nelson, Dana. "Consolidating National Masculinity: Scientific Discourse and Race in the Post-Revolutionary United States.” In Blair St. George, ed. Possible Pasts: Becoming Colonial in Early America. Ithaca, NY: Cornell University Press, 2000, 201-215.

Newman, Andrew. On Records: Delaware Indians, Colonists, and the Media of History and Memory. Lincoln, NE: University of Nebraska Press, 2012.

Parkinson, Robert G. The Common Cause: Creating Race and Nation in the American Revolution. Chapel Hill, NC: University of North Carolina Press, 2016.

Perdue, Theda. Slavery and the Evolution of Cherokee Society, 1540-1866. Knoxville: University of Tennessee, 1979.

Piker, Joshua. "Lying Together: The Imperial Implications of Cross-Cultural Untruths." The American Historical Review 116, no. 4 (October 1, 2011): 964-986.

- The Four Deaths of Acorn Whistler: Telling Stories in Colonial America. Cambridge, MA: Harvard University Press, 2013.

Pratt, Mary Louise. Imperial Eyes: Travel Writing and Transculturation. New York: Routledge Publishing, 1992.

Rana, Aziz. The Two Faces of American Freedom. Cambridge: Harvard University Press, 2014.

Saunt, Claudio. “'Domestick . . . Quiet Being Broke’: Gender Conflict Among Creek Indians in the Eighteenth Century." In F. J. Teute and R. L. Cayton, eds. Contact Points. Chapel Hill, NC: University of North Carolina Press, 1998.

- "The English Has Now a Mind to Make Slaves of Them All: Creeks, Seminoles, and the Problem of Slavery." American Indian Quarterly 22 (1998): 157-181.

- A New Order of Things: Property, Power, and the Transformation of the Creek Indian, 1733-1816. New York: Cambridge University Press, 1999.

Schueller, Malini Johar, and Edward Watts, eds. Messy Beginnings: Postcoloniality and Early American Studies. New Brunswick, NJ: Rutgers University Press, 2003.

Scott, James C. Domination and the Arts of Resistance: Hidden Transcripts. New Haven, CT: Yale University Press, 1992.

Shoemaker, Nancy, ed. Negotiators of Change: Historical Perspectives on Native American Women. New York: Routledge, 1995.

Smallwood, Stephanie. Saltwater Slavery: A Middle Passage from Africa to American Diaspora. Cambridge: Harvard University Press, 2007.

Sobel, Mechal. World They Made Together: Black and White Values in Eighteenth Century Virginia. Princeton, NJ: Princeton University Press, 2003. 


\section{Introduction}

Spivak, Gayatri. "Can the Subaltern Speak? Speculations on Widow-Sacrifice." Wedge 7/8 (Winter/Spring 1985): 120-130.

St. George, Robert Blair, ed. Possible Pasts: Becoming Colonial in Early America. Ithaca, NY: Cornel University Press, 2000.

Starr, Rebecca. A School for Politics: Commercial Lobbying and Political Culture in Early South Carolina. Baltimore: Johns Hopkins University Press, 1998.

Stern, Jessica. The Lives of Objects: Native Americans, British Colonists, and Cultures of Labor and Exchange in the Southeast. Chapel Hill, NC: University of North Carolina Press, 2016.

Stewart, Lynn. "Louisiana Subjects: Power, Space and the Slave Body.” Ecumene 2, no. 3 (July 1995): 227-245.

Stoler, Ann Laura. Race and Education of Desire: A Colonial Reading of Foucault's History of Sexuality. Durham: Duke University Press, 1997.

- "Tense and Tender Ties: The Politics of Comparison in North American History and (Post) Colonial Studies." Journal of American History 88, no. 3 (2001): 829-865.

- Haunted by Empire: Geographies of Intimacy in North American History. Durham: Duke University Press, 2006.

Sweet, John Wood. Bodies Politic: Negotiating Race in the American North, 1730-1830. Baltimore: Johns Hopkins University Press, 2003.

Thomas, Nicholas. Colonialism's Culture: Anthropology, Travel, and Government. Princeton, NJ: Princeton University Press, 1994.

Thornton, John K. "African Dimensions of the Stono Rebellion." The American Historical Review 96, no. 4 (1991): 1101-1113.

- Africa and Africans in the Making of the Atlantic World, 1400-1800. Cambridge: Cambridge University Press, 2nd expanded ed., 1998.

Veracini, Lorenzo. "Telling the End of the Settler Colonial History." In F. Bateman and L. Pilkington, eds. Studies in Settler Colonialism: Politics, Identity, and Culture. New York: Palgrave Macmillan, 2011, 204-218.

Vines, Richard. A Treatise of the Institution . . of the Lords-Supper. London: Miller u.a, 1677.

Walcot, James. The New Pilgrim's Progress: Or the Pious Indian Convert. Containing a Faithful Account of Hattain Gelashmin . . baptis'd . . . George James ... By James Walcot, A.M. London: Printed for M. Cooper, 1748.

Wheatley, Phillis. Poems of Phillis Wheatley: A Native African and a Slave. Bedford, MA: Applewood Books, 1995.

Willinsky, John. Learning to Divide the World: Education at Empire's End. Minneapolis: University of Minnesota Press, 1998.

Wolfe, Patrick. "Land, Labor, and Difference: Elementary Structures of Race." American Historical Review 106 (2001): 868.

- Traces of History: Elementary Structures of Race. London: Verso, 2016.

Wood, Peter. Black Majority: Negroes in Colonial South Carolina from 1670 Through the Stono Rebellion. New York: Norton, 1974.

Woody, Thomas. History of Women's Education in the United States. Vol. 2. New York: The Science Press, 1929.

Wyss, Hilary E. Writing Indians: Literacy, Christianity, and Native Community in Early America. Amherst: University of Massachusetts Press, 2002.

- English Letters and Indian Literacies: Reading, Writing, and New England Missionary Schools. Philadelphia: University of Pennsylvania Press, 2012. 


\section{References}

1. Sven Beckert, The Empire of Cotton: A Global History (New York, 2014), xv. The sixteenth-century explorations of Native America by Spanish soldiers, such as Tristan de Luna and Hernan Desoto, went through parts of the Lower South. Sixteenth- and seventeenth-century Spanish Catholic missions were located on the coast too, especially at St. Catherine's Island and Sapelo Island, just south of the mouth of the Savannah River. See: Robbie Ethridge and Sheri M. Shuk-Hall, Mapping the Mississippi Shatter Zone: The Carolina Indian Slave Trade and Regional Instability in the American South (Lincoln, NB, 2009); Rebecca Saunders, Stability and Change in Guale Indan Pottery: A.D. 1300-1702 (Tuscaloosa, AL, 2000), esp. chapters 6 \& 7; Marvin T. Smith, Coosa: The Rise and Fall of a Mississippian Chiefdom (Gainesville, FL, 2000), esp chap. 3. For examples of the "Lower South" formulation see: Joyce Chaplin, An Anxious Pursuit: Agricultural Innovation and Modernity in the Lower South, 1730-1815 (1993); William Brown, The Lower South in American History (New York, 1903).

2. Anibal Quijano, "The Coloniality of Power, Eurocentrism, and Latin America," Nepentla 1 (2000): 533-580; and Maria Lugones, "Heterosexualism and the Colonial/Modern Gender System," Hypatia 22 (Winter 2007): 186-209. The term "motley crew" is from Marcus Rediker and Peter Linebaugh, The Many-Headed Hydra: Sailors, Slaves, Commoners, and the Hidden History of the Revolutionary Atlantic (Boston, 2000), 332-333.

3. Philip D. Morgan, Slave Counterpoint: Black Culture in the EighteenthCentury Chesapeake and Lowcountry (Chapel Hill, NC, 1998), 1; Kathryn E. Holland Braund, Deerskins and Duffels: Creek Indian Trade with AngloAmerica, 1685-1815 (Lincoln: University of Nebraska Press, 1996); Littlefield, Rice and Slaves. J. Leitch Wright Jr., Creeks and Seminoles: Destruction and Regeneration of the Muscogulge People (Lincoln, NE: University of Nebraska Press, 1986); Robert E. Paulett, An Empire of Small Places: Mapping the Southeastern Anglo-Indian Trade, 1732-1795 (Athens, GA, 2012).

4. David J. Silverman, Thundersticks: Firearms and the Violent Transformation of Native America (Cambridge, 2016), passim and esp. chapter 1; Alan Gallay, Indian Slavery Trade: The Rise of the English Empire in the American South, 1670-1717 (New Haven, 2002), 299; Joel Gascoyne, A True Description of Carolina (London, 1682), 4; William Robert Snell, "Indian Slavery in Colonial South Carolina, 1671-1795.” Ph.D. diss., University of Alabama, 1972, 114124; as quoted and discussed in Timothy Silver, New Face on the Countryside: Indians, Colonists, and Slaves in the South Atlantic Forests, 1500-1800 (New York, 1990), 83, 84; Braund, Deerskins and Duffels, 70-71, 96-98; Daniel H. Usner, Indians Settlers, and Slaves in a Frontier Exchange Economy: the Lower Mississippi Valley before 1783 (Chapel Hill, NC, 1992), 245-247.

5. Silver, A New Face on the Countryside, 82-83.

6. David S. Jones, "Virgin Soils Revisited," William and Mary Quarterly 60 (2003): 703-742; Julie Anne Sweet, Negotiating for Georgia: British-Creek Relations in the Trustee Era, 1733-1752 (Athens, GA, 2005), 190. In 1757, the colonial governor of North Carolina declared that the Catawbas' 1.8 million acres of land was too much for them and should be reduced. South Carolina Journal of the Commons House of Assembly March 5, 1765-April 6, 1766, 56-59. Governor Dobbs to Board of Trade, January 20, 1757, Colonial Records of North Carolina 5 (1887): 739-742. May 14, 1717, Journal of the Commissioners of the Indian Trade (1955), 179-182, 203, and 292-293.

7. Peter Wood, Black Majority: Negroes in Colonial South Carolina from 1670 Through the Stono Rebellion (New York, 1974), 152. 
8. Good conjectures for the Lower South support the claim of unequal distribution of growth in the region: Peter C. Mancall et al., "Conjectural Estimates of Economic Growth in the Lower South: 1720-1800," in William A. Sundstrom, et al., eds., History Matters: Essays on Economic Growth, Technology, and Demographic Change (Stanford, CA, 2003), 389-410 (esp. 391-392) and Walter B. Edgar, South Carolina: A History 78 (104,000 Africans in South Carolina); Betty Wood, Slavery in Colonial Georgia 89 (15,000 Africans in Georgia); Edda L. Fields-Black, Deep Roots: Rice Farmers in West Africa and the African Diaspora (Bloomington: Indiana Universitry Press, 2008), 172.

9. Judith Ann Carney, Black Rice: The African Origins of Rice Cultivation in the Americas (2001), passim; Fields-Black, Rice Farmers, 172.

10. Daniel K. Richter, Facing East from Indian Country (Cambridge, MA, 2003), 3-7; Neal Salisbury, "The Indians' Old World: Native Americans and the Coming of Europeans," William \& Mary Quarterly, 3rd ser., 53 (1996): 435-458.

11. Stephanie Smallwood, Saltwater Slavery: A Middle Passage from Africa to American Diaspora (Cambridge, MA, 2007), 35-36; David Eltis, The Rise of African Slavery in the Americas (Cambridge, 1999), 155-158.

12. On disease: Jones, "Virgin Soils Revisited,". For more extensive ethnohistory of trade, exchange, and Native confederacies and towns in the Southeast, see: Jessica Stern, The Lives of Objects: Native Americans, British Colonists, and Cultures of Labor and Exchange in the Southeast (Chapel Hill, 2016); Patricia Wickman, The Tree That Bends: Discourse, Power, and the Survival of the Maskókî People (Tuscaloosa, AL, 1999); Saunt, A New Order of Things; Braund, Deerskins and Duffels; Usner, Indians, Settlers, and Slaves in a Frontier Exchange Economy; Silver, A New Face on the Countryside; Theda Perdue, Cherokee Women: Gender and Culture Change, 1700-1835 (Lincoln, NE, 1998); Tom Hatley, The Dividing Paths: Cherokees and South Carolinians through the Era of Revolution (New York, 1993); Michael P. Morris, The Bringing of Wonder: Trade and the Indians of the Southeast, 1700-1783 (Westport Connecticut, 1999); Allan Gallay, The Indian Slave Trade: The Rise of the English Empire in the American South (New Haven, 2002); Joshua Piker, Okfuskee: A Creek Indian Town in Colonial America (Cambridge, 2004); Robbie Ethridge, Creek Country: The Creek Indians and their World (Chapel Hill, NC, 2003); Steven C. Hahn, The Invention of the Creek Nation, 1670-1763 (Lincoln, NE, 2004).

13. Norris as quoted in Jack P. Greene, Selling a New World: Two Colonial South Carolina Promotional Pamphlets by Thomas Nairne and John Norris (Columbia, 1989), 27-28 (n.5), 79, 81, 86-87. Gallay, Indian Slavery, 299. Wood, Black Majority, 124-130.

14. Virginia DeJohn Anderson, Creatures of Empire: How Domestic Animals Transformed Early America (Oxford, 2004), 114 and passim; Allan Greer, "Commons and Enclosure in the Colonization of North America," AHR 117 (2012), 381.

15. Greer, "Commons and Enclosure in the Colonization of America," 366 (quote). See Patricia Wickman's discussion of power and gender and the divisions between Creeks and colonials in The Tree That Bends, 16-18, 82-102.

16. Edmund Morgan, American Slavery, American Freedom (New York, 1975), 70-98; William Cronin, Changes in the Land. John Locke is often cited as the author of the 1669 "constitution" of South Carolina, but he was probably not the only author of the document: Mark Goldie, ed., Locke: Political Essays (Cambridge, 2007), 160-189; Scott L. Malcomson, One Drop of 
Blood: The American Misadventure of Race (New York: Farrar, Straus and Giroux, 2001), 524-525, n.48.

17. These changes in the colonies had parallels elsewhere. After 1700, the number of medical, religious, educational, and moral charities founded in London alone began a gradual expansion. By the 1720s, most urban parishes in England had government-supported, privately funded workhouses. After 1750, E. Jennifer Monaghan has persuasively argued, there was a transformation in family and schooling reflecting new ideas about children, commercialization, and secularization. See E. Jennifer Monaghan Learning to Read and Write in Colonial America: Literacy Instruction and Acquisition in Cultural Context (Amherst, MA, 2005), 6-7, 302-332; Thomas Walter Laqueur, Religion and Respectability: Sunday Schools and Working Class Culture, 1780-1850 (New Haven, Conn., 1976), 1-3; David Owen, English Philanthropy: 1660-1960 (Cambridge, MA, 1964), 52-57; and Tim Hitchcock, English Sexualities, 1700-1800 (New York, 1997), 103-104. Berkeley as quoted in David Hall, Cultures of Print: Essays in the History of the Book (Amherst, MA, 1996), 79.

18. For the classic account of the South Sea Bubble see: Charles Mackay, Extraordinary Popular Delusions and the Madness of Crowds (New York, 1972 [1841]) and Anon, The Second Part of the South Sea Bubble (Boston, 1721) in Andrew McFarland Davis, Colonial Currency Reprints, 1682-1751 (Boston, 1911), 2: 304-332; Peter Dickson, The Financial Revolution in England: A Study of the Development of Public Credit (Oxford, 1967), esp. Chapter 5; P.J. Cain and A.G. Hopkins British Imperialism: 1688-2000, 2nd Edition (London, 2002), 76-79; John Toland, "The Secret History of the South Sea Scheme," in A Collection of Several Pieces of Mr. Toland . . . (London, 1726), 404, 405, 432. On Cato's Letters see: Bernard Baylin, The Ideological Origins of the American Revolution (Cambridge, 1967), 36, and John Trenchard and Thomas Gordon, Cato's Letters: Essays on Liberty, Civil and Religious, and Other Important Subjects (New York, 1969): of the first ten "letters," six focused on political implications of the South Sea "scheme."

19. Rodney Baine, "New Perspectives on Debtors in Colonial Georgia," GHQ 77 (1993): 1-19; Rodney Baine, “Oglethorpe's Forty Irish 'Convicts,'” GHQ 77 (1994): 326-338; Chaplin, An Anxious Pursuit, 38-41, 116-119. A more extensive discussion of the historiography of Georgia's founding is available in James O'Neil Spady, "Bubbles and Beggars and the Bodies of Laborers: The Georgia Trusteeship's Colonialism Reconsidered," in Constructing Early Modern Empires: Proprietary Ventures in the Atlantic World, 1500-1750 (Leiden, The Netherlands: Brill, 2007), 215-216. On mercantilist reform thinking see discussions of "political arithmetic" in David Armitage, The Ideological Origins of the British Empire (Cambridge, 2000), Introduction and Chapter Six, esp. 3-4, 146-149, and 168-169.

20. Benjamin Martyn, Reasons for Establishing the Colony of Georgia . . . (London, 1733), 19-20; "An Appeal for the Georgia Colony (1732)," The Publications of James Edward Oglethorpe, Rodney M. Baine, ed. (Athens, GA, 1994), 160-161. For examples of Oglethorpe's citation of William Penn's vision of Pennsylvania as reformative see pp. 167-168 and 190. "Manuscripts of Dr. Bray's Associates, Minute Book, 1729-1732" as cited in Rodney M. Baine, "James Oglethorpe and the Early Promotional Literature for Georgia,” WMQ, 3rd Ser., 45, no. 1 (1988): 100-106. "Charter of Georgia, June 9, 1732," in Francis Newton Thorpe, comp. and ed., The Federal and State Constitutions Colonial Charters, and Other Organic Laws of the States, Territories, and Colonies Now or Heretofore Forming the United States of America (Washington, DC, 1909), 1822, 1834-1835. Richard Dunn, "The 
Trustees of Georgia and the House of Commons, 1732-1752," WMQ, 3rd Ser., 11 (1954): 551-565; and Betty Wood, "The Earl of Egmont and the Georgia Colony," in Jackson and Spalding, eds., Forty Years of Diversity, 90-91. Betty Wood, Slavery in Colonial Georgia, 1730-1775 (Athens: University of Georgia Press, 1984), ch. 1. For their modernity, see Michel Foucault, Madness and Civilization: A History of Insanity in the Age of Reason, Richard Howard, trans. (New York, 1965), chapter 2 and Foucault, Discipline and Punish: The Birth of the Prison, Alan Sheridan, trans. (New York, 1977), 138 and Michel Foucault, The History of Sexuality: Volume 1, an Introduction, Robert Hurley, trans. (New York, 1978), 94.

21. Lee Ann Caldwell, "New Deal on a New Frontier: European Women Colonists and Trustee Policy, 1733-1752," Journal of the Georgia Association of Historians 16 (1995): 106-126, on the gender patterns within the Trustees' policies. Caldwell's large sample of women in the colony (864 on the Trustees' accounts) allows her to see the gender dynamic of the Trusteeship as no other previous historian has been able to. Despite an early preference for sending men as defenders of the colony against Spain, the Trustees soon developed a high valuation of women. Women were valuable not only as wives and mothers but as servants too. Women rarely controlled land. Egmont, Journal, 8-11, 23, 31, 36, 48-53, 78, 84, 96, 263, 345-347, 351, and 359. Wood, "The Earl of Egmont and the Georgia Colony," 80-96. Causton to Trustees, Savannah, March 10, 1735, Egmont Mss. typescript, 14200, pt.2, pp. 248-249; Causton to Trustees, January 16, 1735, Savannah, Egmont mss typescript, 14200, pt.2, pp. 178; Elizabeth Bland to Oglethorpe, Savannah, June 14, 1735, Egmont mss. typescript, v.14201, pt. 2, pp. 17-20. For the Trustees correspondence, I cite the Egmont Typescript copies of the Phillips Collection of Georgia correspondence at the University of Georgia's Hargrett Reading Room. Many but not all of the letters have been published in Mills Lane, ed., General Oglethorpe's Georgia: Colonial Letters, 1733-1743, 2 vols (Savannah, 1990 [1975]) and Allen D. Candler, comp., The Colonial Records of the State of Georgia, 1732-1782 (Atlanta, GA, 1904-1916), volumes 29-31. Causton to Oglethorpe, Savannah, March 24, 1735, Egmont MSS typescript, v.14200, pt.2, 277-283. Gerald L. Cates, “'The Seasoning': Disease and Death among the First Colonists of Georgia," GHQ 64 no. 2 (1980): 146-158. Egmont, "Typescripts," 14200 part 2, p. 187. Thomas Causton to the Trustees, Savannah, January 13, 1735, Egmont Mss. Typescript v. 14200, pt. 2, pp. 180-182: this letter is January 16, 1735 in Mills Lane, ed., Oglethorpe's Georgia, 92. Thomas Causton to the Trustees, Savannah, January 13, 1735, Egmont Mss. Typescript v. 14200 , pt. 2, pp. 180-182: this letter is January 16, 1735 . Trustees to Oglethorpe, [Westminster], March 17, 1734, Egmont Mss. vol. 14207, 68-70. Patrick Mackay to Anonymous, Coweta, March 27, 1735, 14200, pt. 2, pp. 324-325. Stephens, Journal, 42-43. Quincy to Gordon, Savannah, March 3, 1735 Egmont MSS typescript, v.14200, pt.2, pp. 245-246. Causton to Trustees, Savannah, March 10, 1735. Egmont MSS Typescript, v.14200, pt.2, pp. 250-252. Grumblestorians: Patrick Mackay to Anonymous, Coweta, March 27, 1735, 14200, pt. 2, pp. 325; Causton to Oglethorpe, Savannah, March 24, 1735, Egmont Mss. Typescript, v.14200, pt.2, pp. 280.

22. Mr. Sergeant's Proposal of a More effectual Method for the Education of Indian Children ... (Boston, 1743), 3, 5. Huntington Library. Indian Song of Peace: with a Proposal ... for Erecting Indian Schools ... (New York, 1752), 5-7, 25-26. Huntington Library. The author also argues that British subjects should learn Indian languages and run schools. And a letter to the "ladies of New York" and purporting to be by an Indian named "Yariza" pleads to 
learn English and how to obey virtuous commands. Wheelock, A Brief Narrative of the Indian Charity-School in Lebanon in Connecticut, New England ... (London, 1767 [Boston 1763]), 8. Rare Book Room, Swem Library Special Collections, William and Mary. Alexander Garden, South Carolina Gazette, March 28, 1743. Sweet, Negotiating for Georgia.

23. John Lawson, A New Voyage to Carolina . . . (Ann Arbor, 1966 [1709]), 180-181.

24. Ibid., 183-185, 187, 191-192, 213-215; John Brickell, The Natural History of North Carolina . . . (Dublin, 1737), 178-179, 182-184, 290-291.

25. Silver, New Face on the Countryside, 82-83. Theda Perdue, Cherokee Women: Gender and Culture Change, 1700-1835 (Lincoln, NE, 1998), "Conclusion," 183-195. Matrilineages were common to most Native Americans in the region. See: Charles M. Hudson, Southeastern Indians (Knoxville, TN, 1978), 185; Greg Urban and Jason Baird Jackson, "Social Organization," in Handbook of the North American Indians, Volume 14, William Sturtevant, general ed., and Raymond D. Fogelson, volume ed. (Washington, 2004), 697. Colonial Records of North Carolina (1887), May 26, 1756, v. 5: 579-584 (importance of women) and "Committee of Conference Report, June 8 1748," South Carolina Journal of the Commons House of Assembly, January 19 1748-June 29, 1749 (items: calico, a pair of ear bobs, a mirror, and a piece of gartering). Native men supplied hides and also served as runaway slave catchers for the colonials: "Message of January 21, 1711," South Carolina Journal of the House of Commons, January 11, 1711-March 1, 1711: 273-274 (Indians employed in capturing escaped slaves); "Order of February 28 1766," South Carolina Journal of the Commons House of Assembly (January 7, 1766-May 9, 1767), 76-77; "Report of December 11, 1768," Colonial Records of North Carolina 8 (1890): 555-561. Finally, Indian warriors and hunters traded information about the movements of Indians and the French in particular: Silver, A New Face on the Countryside, 83-84; Ethridge, Creek Country, 74; and Perdue, Cherokee Women, 42, 80.

26. The Creek Confederacy should not be mistaken for an ethnic or linguistic community. Most spoke Muskogee, but the confederacy itself was a political organization of diverse and autonomous towns formed after the Yamassee War (1715-1716). Vernon James Knight, Jr., “The Formation of the Creeks," in Charles Hudson and Carmen Chaves Tesser, eds., The Forgotten Centuries: Indians and Europeans in the American South, 1521-1704 (Athens, GA, 1994), 373-375, 390; and Hahn, Creek Nation, 7, 279-280 n.17.

27. Nancy Shoemaker, A Strange Likeness: Becoming Red and White in Eighteenth Century America (Oxford, 2004), 4-6 has a similar discussion of this map. There are disagreement and ambiguity about the date. Piker, Okfuskee, 36-39; Gregory A. Waselkov, "Indian Maps of the Colonial Southeast," in Peter Wood et al., eds., Powhatan's Mantel: Indians in the Colonial Southeast (Lincoln, NE: University of Nebraska Press, 1989), 297-298, 324-332.

28. Gregory Evans Dowd, Spirited Resistance: The North American Indian Struggle for Unity, 1745-1815 (Baltimore, 1992), passim.

29. Gregory Evans Dowd, War under Heaven: Pontiac, the Indian Nations, and the British Empire (Baltimore, 2004), 101-105.

30. Stephens, Journal, v.2, 128-130 and "An Account ..." in Candler and Northern, comps., Colonial Records of the State of Georgia, v.22, pt.2, 232-236. The Reverend Leslie to SPG Secretary, St Paul's Parish, South Carolina, January 7, 1740. Wood, Black Majority, 314-319. John K. Thornton, "African Dimensions of the Stono Rebellion," American Historical Review 96 (1991): 1101-1113. 
31. Brickell, The Natural History of North Carolina, 263. Morgan, Slave Counterpoint, 447 (and n. 9) and 448 (and n. 10); Calumnies, 63. Other evidence of runaway communities: "Charleston," the South Carolina Gazette, July 10, 1736 (p. 3); South Carolina Journal of the Commons House of Assembly (September 12, 1739-May 10 1740), 284-286. John J. Tepaske, "The Fugitive Slave: Intercolonial Rivalry and Spanish Slave Policy, 1687-1764," in Samuel Proctor, ed., Eighteenth Century Florida and Its Borderlands (Gainesville, FL, 1975), 1-12; Jane Landers, "Spanish Sanctuary: Fugitives in Florida, 1687-1790." Florida Historical Quarterly 42 (1984): 296-313; and Jane Landers, "Gracia Real de Santa Maria de Mose: A Free Black Town in Spanish Colonial Florida," AHR 95 (1990): 9-30; South Carolina Gazette, September 17, 1772; Georgia Gazette (Savannah), December 7, 1774, as quoted in Frey, Water from the Rock, 54. Papers of Henry Laurens, 10: 206-208, 231-232 as quoted in Frey Water from the Rock, 54, 61-62, 120. "November 15, 1765," Journal of the Commons House of Assembly, January 17, 1763, to December 24, 1768, Inclusive, Allen D. Candler, comp., in Candler and Lamar, comps., Colonial Records of Georgia, 14: 292-293. Morgan, Slave Counterpoint, 450, 451; Wendy Gonaver, "Race Relations: A Family Story, 1765-1867," (MA Thesis, College of William and Mary, 2001), 11-12; Harold E. Davis, The Fledgling Province: Social and Cultural Life in Colonial Georgia, 1733-1776 (Chapel Hill, NC, 1976), 139. Lathan A. Windley, Runaway Slave Advertisements: Georgia (Westport, Connecticut: Greenwood Press, 1983), 23, 62; Jonathan Clarke to "Dear Brother," Savannah, January 19, 1790, in Journal of Negro History 1 (1916): 77-79.

32. Gronniosaw, Narrative, 26, 34. Joanna Brooks and John Saillant, Face Zion Forward: First Writers of the Black Atlantic (Boston, 2002). Henry Louis Gates Jr., "James Gronniosaw and the Trope of the Talking Book," in William L. Andrews, ed., African American Autobiography: A Collection of Critical Essays (Englewood Cliffs, NJ, 1993), 12.

1. Chekilli Paper, 1735. Georgia Historical Society. This quote is from a Creek origins story that was taken down from Chekilli and others at Savannah on June 11, 1735, in the presence of Thomas Causton and others of the first Georgia colonists.

2. Equiano, 27-28; Vincent Carreta, Equiano, the African (New York, 2007), 143-144.

3. Megan Kate Nelson, Trembling Earth: A Cultural History of the Okefenokee Swamp (Athens, GA, 2005), esp. chapter 1. Jane Landers, "Spanish Sanctuary: Fugitives in Florida, 1687-1790," Florida Historical Quarterly 42 (1984): 301: Twenty three men, women, and children had arrived in St Augustine from Port Royal November 21, 1738; John J. TePaske, “The Fugitive Slave: Intercolonial Rivalry and Spanish Slave Policy, 1687-1764," in Samuel Proctor, ed., Eighteenth Century Florida and Its Borderlands (Gainesville, FL, 1975), 2-3, 6-7; Daniel F. Littlefield, Africans and Creeks: From the Colonial Period to the Civil War (Westport, CT, 1979), 14, 17, and passim.

4. Knox Mellon Jr., "Christian Prieber's Cherokee 'Kingdom of Paradise," Georgia Historical Quarterly 57 (1973): 319-331. S.C. Williams, "Presbyterian Mission to the Cherokees, 1757-59," Tennessee Historical Magazine 1 (N. S.): 125. Alan Gallay, Indian Slavery Trade: The Rise of the English Empire in the American South, 1670-1717 (New Haven, 2002), 298-300; Francis Le Jau, The Carolina Chronicle of Francis Le Jau, 1706-1717, Frank Klingberg, ed. (Berkeley, CA, 1956), 136, 156. See also Robert E. Paulett, An Empire of Small Places: Mapping the Southeastern Anglo-Indian Trade, 
1732-1795 (Athens, GA, 2012) on how colonials involved in the deerskin trade learned to make spaces their own.

5. Though one could consider such cultural production as "creolization," my approach is more directly influenced by ideas of "hybridity." See: Homi K. Bhabha, "Signs Taken for Wonders: Questions of Authority and Ambivalence under a Tree outside Delhi, May 1817," in The Location of Culture (New York, 1994), 145-174 and E. San Juan, “'Unspeakable' Subalterns: Lessons from Gramsci, El Saadawi, Freire, Silko," in Beyond Postcolonial Theory (New York: St. Martin's Press, 1999), 83-112.

6. In both Native American studies and studies of African American slavery there have been a variety of positions on "authenticity," "instrumentality," "preservationist," and "modern" dimensions of subjectivity. For examples, see James Axtell, "Were Indian Conversions Bona Fide?" After Columbus: Essays in the Ethnohistory of Colonial North America (Oxford, 1988), 100-121 (Axtell explicitly debates Francis Jennings, Neal Salisbury, David Blanchard, Cornelius Jaenen, Allen Trelease, and Bruce Trigger). See also Eugene Genovese, From Rebellion to Revolution: Afro-American Slave Revolts in the Making of the Modern World (Baton Rouge, Louisiana, 1992 [1979]), 3, 11-12; Carolyn Fick, Making Haiti; Geggus, Haitian Revolutionary Studies (Knoxville, 1990), 65. See also Stefanie Smallwood, Saltwater Slavery: A Middle Passage from Africa to American Diaspora (Cambridge, 2007); Daniel K. Richter, Facing East from Indian Country (Cambridge, MA, 2001); Gregory Evans Dowd, A Spirited Resistance (Baltimore, 1992) and Sylvia Frey and Betty Wood, Come Shouting to Zion (Chapel Hill, NC, 1998).

7. Claudio Saunt has argued that European imperial rivalry tended to fragment hierarchies within the Creek community. He has shown this dynamic at work between male political and war leaders and between women and men. My arguments here fundamentally complement his by showing how fragmentation and new cultural creativity were learned within a colonized Southeast. See: Claudio Saunt, A New Order of Things: Property, Power, and the Transformation of the Creek Indians, 1733-1816 (New York, 1999). See also Saunt, "Taking Account of Property: Social Stratification among the Creek Indians in the Early Nineteenth Century," The William and Mary Quarterly 24 (2000): 733-760 and "The English has now a Mind to make Slaves of them all': Creeks, Seminoles, and the Problem of Slavery," American Indian Quarterly 22 (1998): 157-181; “ 'Domestick . . Q Quiet being broke': Gender Conflict among Creek Indians in the Eighteenth Century," in F. J. Teute and R. L. Cayton, eds., Contact Points (Chapel Hill, NC, 1998).

8. Elam Potter, "An Account of Several Nations of Southern Indians. In a Letter from Reverend Elam Potter to Reverend Dr. Stiles, A.D. 1768," Massachusetts Historical Society Proceedings, 1st Ser., 10 (1809): 119-121. Hilary E. Wyss, Writing Indians: Literacy, Christianity, and Native Community in Early America (Amherst, 2000); Margaret Connell Szasz, Indian Education in the American Colonies, 1607-1783 (Albuquerque, 1988).

9. Henry Timberlake, Memoirs of Lieut. Henry Timberlake ... (London, 1765), $72,73,76$.

10. Allen Candler, comp., The Colonial Records of the State of Georgia, 17321782, vol. 16 (Atlanta, 1904-1916), 221-223; Joseph Caldwell and Catherine McCann, Irene Mound Site: Chatham County Georgia (Savannah: WPA Archaeological Project, 1941), 77-78.

11. Perdue, Cherokee Women, 78, 117, 144, 162-164, 170; Joshua Piker, Okfuske: A Creek Indian Town in Colonial America (Cambridge, 2004), 160, 
166; Joel W. Martin, Sacred Revolt: The Muskogees' Struggle for a New World (Boston: Beacon, 1991), 115.

12. Journal of Egmont, 272-273 (Oglethorpe quotes).

13. Ibid., 58.

14. Edmond Atkin, Indians of the Southern Frontier: The Edmond Atkin Report and Plan of 1755, Wilbur R. Jacobs, ed. (Columbia, 1954), 10; James Adair, and Samuel Cole Williams, Adair's History of the American Indians (New York: Published for University Microfilms, Ann Arbor by Argonaut Press, 1966), 164-165.

15. Journal of Egmont, 103 (August 27, 1735).

16. Ibid.

17. Ibid., 60-61.

18. James Oglethorpe to John Phillips as quoted in Sweet, Negotiating for Georgia, 43. The other priority was "That we would settle conditions of trade ..." Journal of Egmont, 62.

19. Journal of Egmont, 60-61.

20. Ibid., 62.

21. Ibid., 57: "Tomochachi, His wife, Toonaway his Gr. Nephew, 5 others and an interpreter (Mr. Musgrove)." The "wife" and "Gr. Nephew" hint at this being partly a matrilineal group. Journal of Egmont, 64.

22. "A Curious Account of GEORGIA by an Honourable Person," in Anonymous, A New Voyage to Georgia (London, 1737), 57-62 (quote 57).

23. Journal of Egmont, 131-132, 216-217.

24. "A Curious Account of GEORGIA by an Honourable Person," in Anonymous, A New Voyage to Georgia (London, 1737), 57-62 (quote 59).

25. Journal of Egmont, 272.

26. Candler, Colonial Records of the State of Georgia, vol. 36, 256-271. One of the orders issued in the process of her battle for land, see: Henry Ellis to Henry Monge and William De Brahm, December 4, 1759, GHS. Edmund Akin to Henry Ellis, Fort Moore, January 25, 1760 and Gov Henry Ellis to "The King's beloved Men and Head Warriors of the upper and lower Creek Nations," February 9, 1760, Henry Ellis Papers. GHS. Mary Musgrove was, for example, an interpreter at a shipboard meeting when John Wesley arrived as missionary to her community. See: Journal of Egmont, 131-132. Regarding Musgrove's Christian education, the Demere Family Bible at the GHS. Its provenance notes within it a claim that it was brought from England by The Revd. Bosomworth when he arrived in Georgia and that it was a Bible Musgrove used as well: THE HOLY BIBLE, Containing the OLD and NEW TESTAMENTS: Newly Translated out of the Original Tongues: And with the former TRANSLATIONS Diligently Compared and Revised by his Majesty's Special Command. Appointed to be Read in Churches (Oxford: John Basket, Printer to the University, 1733).

The definitive scholarly work on Mary Musgrove's life and controversies is Stephen Hahn, The Life and Times of Mary Musgrove (Tallahassee, Florida, 2012) and see also Piker, The Four Deaths of Acorn Whistler, chapters 7 \& 8 especially. Mary Bosomworth to Col. Alexander Heron, 10 August 1747, Candler, Colonial Records of the State of Georgia, vol. 36, 256, 259-260 as cited in Doris B. Fisher, "Mary Musgrove: Creek Englishwoman," (Ph.D. diss., Emory University, 1990), 51-54, 80-81. See also Helen Todd, Mary Musgrove: Georgia Indian Princess (Seven Oaks Publishing Co., 1981) and John Pitts Corry, "Some New Light on the Bosomsworth Claims," The Georgia Historical Quarterly 25, no. 3 (1941): 195-224.

27. Colonial Records of Georgia, v.27 (1937), 14, 24-25, 26, 33. 
28. Gottlieb Prieber story: Verner Crane, "A Lost Utopia on the First American Frontier," Sewanee Review 27 (January 1919): 48-61; Mellon Jr., "Christian Prieber's Cherokee 'Kingdom of Paradise," '. Williams, "Presbyterian Mission to the Cherokees, 1757-59,". James Adair was acquainted with Prieber and claimed to have corresponded with him: "a gentleman of a curious and speculative temper."

29. South Carolina Gazette, August 15, 1743.

30. Ludovick Grant, "Historical Relation of Facts ...." South Carolina Magazine of Genealogy and History 10 (1909): 59.

31. Adair, 257, 368.

32. Ibid., 141.

33. James Habersham estimated De Brahm to be "one of the most intelligent men I ever met with." Habersham quoted in Louis De Vorsey, Jr., "Introduction," De Brahm's Report, 10. All the words and phrases cited in the discussion of De Brahm's Cherokee vocabulary are taken from pages 115-131. J. Brikel, Natural History of North Carolina (Dublin 1737) offers a shorter pidgin vocabulary. For biographical information on De Brahm see Louis de Vorsey, J., "De Brahm's East Florida on the Eve of the Revolution," in Samuel Proctor, ed. Eighteenth Century Florida and Its Borderlands (Gainesville: University Presses of Florida, 1975), 78-96.

34. See Axtell, "Babel of Tongues: Communicating with the Indians in Eastern North America and Goddard, The Use of Pidgins and Jargon's in Eastern North America," in Edward G. Gray and Norman Fiering, eds., The Language Encounter in the Americas, 1492-1800: A Collection of Essays (New York, 2000), 15-60, 61-80; Karen Ordahl Kupperman, Indians and English: Facing off in Early America (Ithaca, NY, 2000), 32, 79, 86-87.

35. De Vorsey, Jr., ed., De Brahm's Report, 115-131.

36. Adair, 133-135.

37. Ibid.

38. Thomas Bosomworth. "Journal of Thomas Bosomworth," in William L. McDowell, ed., Documents Relating to Indian Affairs (Columbia, SC, 1970), 268-294, Appendix 330-335.

39. A Treaty Held with the Catawba and Cherokee Indians . . . February and March 1756 (Williamsburg, VA, 1756), 3 (quote), 15-16 (Culloughculla). Huntington Library. Timberlake, Memoirs of Lieut. Henry Timberlake, 40-41. Huntington Library. As late as 1816, this learned caution about language can be witnessed at meetings: "Journal of the Proceedings . . . to hold conferences and settle a treaty or treaties with the Chickasaw and Cherokee Tribes," Jesse Franklin Indian Treaty Papers, Southern Historical Collection, UNC. Cherokees express reticence about consenting to an agreement because "they had no witnesses with them, their Old People and Traders having been left in the nation."

40. Davie, Mission Journal (1758-1759). William Richardson Davie Papers, 1758-1819. GHS. The journal is addressed as a letter to The Revd Samuel Davies, Secty, The Society for Managing the Mission and Schools among the Indians.

41. Ibid.

42. Ibid.

43. Samuel C. Williams, "Christian Missions to the Overhill Cherokees," Chronicles of Oklahoma 12, no. 1 (March 1934): 67-72.

44. Bartram, Travels Through North \& South Carolina, Georgia, East \& West Florida" the Cherokee Country, the Extensive Territories of the Muscogulges, or Creek Confederacy, and the Country of the Chactaws (Pennsylvania, 
1791), 297; and Tom Hatley, Dividing, Paths: Cherokees and South Carolinians through the Era of Revolution (New York, 1993), 216-217; Perdue, Cherokee Women, 55; Schwarze, History of the Moravian Missions, 34, 38.

45. Landers, "Spanish Sanctuary," (esp. 297, 299, 300); Jane Landers, "Gracia Real de Santa Maria de Mose: A Free Black Town in Spanish Colonial Florida,” AHR 95 (1990): 9-30.

46. John K. Thornton, "African Dimensions of the Stono Rebellion," AHR (1991): 1101-1113; Sylvia Frey, Water from the Rock: Black Resistance in a Revolutionary Age (Princeton, 1991); Wood, Black Majority; Genovese, From Rebellion to Revolution, proposes a typology of slave rebellion. The typology has been rejected, but his "preconditions" list is useful still: (1) absenteeism among slave owners and greater distance between white and black populations; (2) economic distress, famine; (3) slaveholding units as large as 100 or 200 people; (4) a split within the slaveholding class either through warfare with other countries or within one colony; (5) a black majority; (6) more African-born slaves than creoles; (7) autonomous black leadership within the slave society; and (8) geography conducive to marronage. Many of these conditions existed in Georgia and South Carolina. At various times during the eighteenth century and early in the nineteenth century, all or several of these preconditions were visible in Georgia and South Carolina.

David Geggus has summarized the various typologies of Genovese, Michael Craton, and other historians and has suggested that "the extreme difficulty of deciphering rebels' intentions" has made typology imprecise. See Geggus, Haitian Revolutionary Studies, 65.

47. Papers of Henry Laurens, 10: 206-208, 231-232 and Georgia Gazette (Savannah), December 7, 1774, both as cited in Frey, Water from the Rock, 54, 61-62. Morgan asserts that overall, 25\% of South Carolina runaways that ran in groups were of one ethnicity. During the middle decades of the eighteenth century, however, Morgan believes that evidence is sufficient to demonstrate a decline in such ethnic-identified marronage with statistical precision. Slave Counterpoint, 447 (and n. 9) and 448 (and n. 10). John Brickell, The Natural History of North Carolina (Dublin, 1737[1969 reprint]), 263. A South Carolina Colonial Assembly resolution in 1711 claimed: "There are several Negroes run away from their masters, and keep out, armed, and robbing and plundering houses and plantations, and putting the inhabitants of this Province in great fear and terror," Calumnies, 63. In an article titled "Charleston," the South Carolina Gazette reported on July 10, 1736 (p. 3) that a group of Catawbas had been robbed by runaway slaves, probably maroons. And a report from February 6, 1740, in the South Carolina Journal of the Commons House of Assembly (September 12, 1739-May 10, 1740), 284-286 discussed payment to Peedee-area Indians for capturing maroon slaves on the Pon Pon River. Morgan, Slave Counterpoint, 450; Tepaske, "The Fugitive Slave: Intercolonial Rivalry and Spanish Slave Policy, 16871764," 1-12; Landers, "Spanish Sanctuary," 296-313; and Jane Landers, "Gracia Real de Santa Maria de Mose," AHR 95 (1990): 9-30. "November 15, 1765," Journal of the Commons House of Assembly, January 17, 1763, to December 24, 1768, Inclusive, Allen D. Candler, comp., in Candler and Lamar, comps., Colonial Records of Georgia, 14: 292-293. I am indebted to Wendy Gonaver for this reference. Morgan, Slave Counterpoint, 450. Wendy Gonaver, "Race Relations: A Family Story, 1765-1867," (MA Thesis, College of William and Mary, 2001), 11-12 (burning plantations); Harold E. Davis, The Fledgling Province: Social and Cultural Life in Colonial Georgia, 1733-1776 (Chapel Hill, 1976), 139 (burning plantations). Lathan 
A. Windley, Runaway Slave Advertisements: Georgia (Westport, CT: Greenwood Press, 1983), 23, 62 (joining maroons).

48. E. Jennifer Monaghan, Learning to Read and Write in Colonial America: Literacy Instruction and Acquisition in Cultural Context (Amherst, MA, 2005), 243.

49. The Georgia Gazette, October 23, 1788.

50. South Carolina Gazette, January 4, 1735-December 30, 1745 (Molly); For later period see December 31, 1772 (lack of skill noted), December 13, 1773 (Dan), September 12, 1774 (emphasis on “exceeding” mine). Gundaker, 96 (quote). I first encountered almost all of the colonial slave ads through-or read only in-Lathan Windley's published series of volumes on runaway ads in the South. For a comparative and thorough perspective on slave literacy in Virginia see: Antonio Bly, "Reed through the Bybell: Slave Literacy in Early Virginia," Book History 16 (2013): 1-33.

51. "Instructions for the Clergy Employed by the Society ...," SPG Journal, 1: 613-615 in Foster, 6, no page numbers. Dr. [Francis] Le Jau to Secrty [SPG], St. James Goose Creek, South Carolina, February 1, 1710, in Gertrude Foster ed., "Documentary History of Education in South Carolina as Revealed in the Manuscripts of the Society for the Propagation of the Gospel in Foreign Parts," (Ed.D., University of South Carolina, 1932), 2: 73; Wood, Black Majority, 314; Georgia Gazette (Savannah), December 7, 1774, and Papers of Henry Laurens, 10: 206-208, 231-232 as quoted in Frey, Water from the Rock, 54 and 61-62, respectively.

52. Figures come from The Journals and Correspondence of SPG ministers in the Draper Manuscripts Microform and as transcribed in Foster, ed., "Documentary History," Morgan, Slave Counterpoint, 420-422; Wood, Black Majority, 323-326.

53. Roe to Secretary, St. George's Parish, SC, December 28, 1741; Roe to Secretary, St. George's Parish, SC, February 20, 1742.; Roe to David Humphreys, St George's Parish, SC, October 1751.

54. Alexander Garden to Revd. Sir, [Charleston], January 31, 1743 in Foster, "Documentary History," 5: 713a (quote).

55. Garden to SPG, Charleston, May 6, 1740, Foster ed., "Documentary History," 5: 699a-699b.

56. Garden to Revd. Sir., Charleston, April 23, 1745; Garden to SPG, Charleston, May 8, 1745; Garden to SPG secretary, Charleston, October 22 1748; and Robert Smith to Bearcroft, Charleston, April 21, 1761: all in Foster ed., "Documentary History," 5: 718, 736, 742, 770, and 789; George C Rogers, Charleston in the Age of the Pinckneys (Columbia, SC, 1980), 90-91.

57. Rules and Regulations of the Brown Fellowship Society, 1-3, 23; Heads of Families . . . 1790, South Carolina Census (Baltimore, 1978), 55. The Mitchell family of Georgetown District, for just one example, owned more than 200 slaves. Morgan, Slave Counterpoint, 648-649.

58. John Marrant, "Narrative," in Adam Potkay and Sandra Burr, eds., Black Atlantic Writers of the Eighteenth Century (New York, 1995), 76-77.

59. Ibid., 76-78. Adam Potkay and Sandra Burr's edition of Marrant's narrative is especially interesting. They identified a "personal edition" Marrant appears to have printed so that he could describe more freely domestic violence within his family, Indians' resentment over white colonialism, and a brutally repressive white mistress. This "fourth edition" of the narrative is the one they published in Black Atlantic Writers of the Eighteenth Century, and it is my source.

60. Marrant, "Narrative," 76-78. 
61. Ibid., 85 .

62. Gundaker, 19-20 and see also her definition of "double voicing" pages 20-22.

63. Marrant, "Narrative," 86.

64. Henry Louis Gates Jr., "James Gronniosaw and the Trope of the Talking Book," in William L. Andrews, ed., African American Autobiography: A Collection of Critical Essays (Englewood Cliffs, NJ, 1993), 12.

65. Marrant, "Narrative," 91.

66. Ibid.

67. John K. Thornton, Africa and Africans in the Making of the Atlantic World, 1400-1800 (Cambridge, 1998), 236.

68. Wood, Black Majority 324; Leon Higginbotham, In the Matter of Color: Race and American Legal Process, the Colonial Period (Oxford, 1978), 168; E. Merton Coulter, Georgia: A Short History (Chapel Hill, NC, 1960 [1933]), 84; "An Act for the Better Ordering and Governing Negroes and Other Slaves in This Province, 1740," in Thomas Cooper and David McCord, eds., The Statutes at Large of South Carolina, vol. 7 (Columbia, South Carolina, 1837), 397-417. Watkins Robert and George Watkins, A Digest of the Laws of the State of Georgia ... (Philadelphia: Aitken, 1800), 163-179.

69. Marrant, "Narrative," 92.

70. The best and standard interpretation of the slavery debate in preRevolutionary Georgia is still Betty Wood, Slavery in Colonial Georgia, 1730-1775 (Athens, GA, 1984). This opposition faction is well-known to historians as the "Malcontents," a faction advocating slavery for the colony as well as other changes to the charter and regulations: Milton Ready, "Philanthropy and the Origins of Georgia," in Harvey H. Jackson and Phinzy Spalding, eds., Forty Years of Diversity: Essays on Colonial Georgia (Athens, GA: University of Georgia Press, 1984), 51-52.

71. Jack P. Greene, "A Plain and Natural Right to Life and Liberty: An Early Natural Rights Attack on the Excesses of the Slave System in Colonial British America," WMQ 57 (2000): 793-808; Milton Ready, “The Georgia Trustees and the Malcontents: The Politics of Philanthropy," GHQ 60, no. 3 (1976): 264-281; Roxann Wheeler, The Complexion of Race: Categories of Difference in Eighteenth-Century British Culture (Philadelphia, 2000).

72. Patrick Talifer et al., "A True Historical Narrative of the Colony of Georgia in America ... (Charleston, SC, 1741)," in Trevor R. Reese, ed., The Clamorous Malcontents: Criticisms and Defenses of the Colony of Georgia, 1741-1743 (Savannah, 1973), 76. From the reprinted remonstrance of various settlers to the Trustees signed by 117 people and dated Savannah, December 9, 1738 .

73. Talifer et al., "A True Historical Narrative of the Colony of Georgia in America ... (Charleston, SC, 1741)," 57, 120.

74. Ibid., 76.

75. An Impartial Enquiry into the State and Utility of the Province of Georgia (London, 1741) in Reese, ed., Clamorous Malcontents, 138.

76. An Impartial Enquiry, in Reese, ed., The Clamorous Malcontents, 139-143. The Trustees were also hearing arguments in favor of slavery, see: James R. Hertzler, "Slavery in the Yearly Sermons before the Georgia Trustees," GHQ 59 (Supplement 1975): 118-126.

77. Ibid., 143.

78. "Deposition of Raymond Demare," January 19, 1739 in An Impartial Enquiry, in Reese, ed., The Clamorous Malcontents, 161.

79. "Deposition of Hugh Mackay,” January 19, 1739 in Ibid., 161-162.

80. "Deposition of John Cuthbert," in Ibid., 162. 
81. Thomas Jones to John Lyde, Savannah, September 18, 1740, in Ibid., 177.

82. The Hard Case of the Distressed People of Georgia, in Reese, ed., The Clamorous Malcontents, 263.

83. Atkins, 60; Garden to SPG, Charleston, May 6, 1740, Foster ed., "Documentary History," 5: 699a-699b; Bolzius, Journal, March 14, 1734 and May 5, 1734; John Wesley to George Whitefield, Savannah, September 10, 1736 in John Telford, ed., The Letters of the Rev. John Wesley, A.M ..., Vol 1. (London, 1931), 204-206. Timberlake, Memoirs of Lieut. Henry Timberlake, 76. The desire to shape the learning of "Indians" or "Negroes" was well expressed repeatedly by several ministers in print. See, for example: [John Sergeant,] A Letter from the Revd. Mr. Sergeant of Stockbridge, to Dr. Colman of Boston . . . Containing Mr. Sergeant's Proposal of a More effectual Method for the Education of Indian Children; to raise 'em if possible into a civil and industrious People; by introducing the English Language among them; and thereby instilling into their Minds and Hearts, with a more lasting Impression, the Principles of Virtue and Piety (Boston, 1743). On page 3 Sergeant proposed "a Method" that he hoped would "change their whole Habit of thinking and acting." He expected teaching to "raise them, as far as possible, into the Condition of a civil industrious and polish'd People." And he wanted "to introduce to English Language among them instead of their own imperfect and barbarous Dialect."

84. South Carolina Gazette, September 17, 1772, as cited in Peter Morgan, Black Majority, 342-343.

85. Habersham to Countess of Huntingdon, Savannah, April 19, 1775 in Collections of the Georgia Historical Society, Vol. 4, Letters of the Honorable James Habersham, 1756-1775 (Savannah, 1904), 241.

86. Habersham to Robert Keen, Savannah, May 11, 1775, in Collections of the Georgia Historical Society, Vol. 4, Letters of the Honorable James Habersham, 1756-1775 (Savannah, 1904), 243-244. Neil J. O’Connell, "George Whitefield and Bethesda Orphan-House," The Georgia Historical Quarterly 55 (1970): 41-62.

1. Paul Cross Papers, Folder 4, South Caroliniana Library, University of South Carolina, Columbia, South Carolina.

2. On the economy see: Peter C. Mancall et al., "Conjectural Estimates of Economic Growth in the Lower South: 1720-1800," in William A. Sundstrom, et al., eds., History Matters: Essays on Economic Growth, Technology, and Demographic Change (Stanford, CA, 2003), 389-410. On the religious and secular character of schools in this period see Monagan, Learning to Read and Write, 197-212 and passim. The 1735 incident is "The Red String Conspiracy," so named because conspirators were identified by "a Red String about the right Wrist." Egmont, Journal, 36; Quincy to Gordon, Savannah, March 3, 1735 Egmont MSS typescript, v.14200, pt.2, pp. 245-246. Causton to Trustees, Savannah, March 10, 1735. Egmont MSS Typescript, v.14200, pt.2, pp. 250-252. Grumblestorians: Patrick Mackay to Anonymous, Coweta, March 27, 1735, 14200, pt. 2, p. 325; Causton to Oglethorpe, Savannah, March 24, 1735, Egmont Mss. Typescript, v.14200, pt.2, p. 280. Quincy to Gordon, Savannah, March 3, 1735 Egmont MSS typescript, v.14200, pt.2, pp. 245-246; Causton to Trustees, Savannah, March 10, 1735. Egmont MSS Typescript, v.14200, pt.2, pp. 250-252; James Habersham to John Wesley, Savannah, June 20, 1739, James Habersham Papers, Box 4, Folder 56, Georgia Historical Society.

3. John E. Murray, "Literacy Acquisition in an Orphanage: A Historical Longitudinal Case Study," American Journal of Education 110 (2004): 172-196; 
Sharon Braslaw Sundue, Industrious in their Stations: Young People at Work in Early America (Charlottesville, VA, 2009), 57-90; Carl Kaestle, Pillars of the Republic: Common Schools and American Society, 1780-1860 (New York, 1983), 195, 201-202; Lawrence A. Cremin, American Education: The Colonial Experience, 1607-1783 (New York, 1970), 517-519, 526, $532-533,542-543$. The argument participates in a long-standing revision of North American education history by emphasizing the social-cultural context of institutional development. Some examples: Newton Edwards and Herman G. Richey, The School and American Social Order (Boston, 1947); Robert L. McCaul, "A Documentary History of Education in Georgia," (PhD. Diss., University of Chicago, 1953), 1, n.1; Bernard Bailyn, Education in the Formation of American Society (Chapel Hill, NC, 1970), 33, 75; Cremin, American Education, ii. For critiques of Cremin see: Robert L. Church et al., "Forum," History of Education Quarterly 29 (1989): 419-437. On "the New Cultural History:" Lynn Hunt, ed., The New Cultural History (Berkeley, 1989); Richard Biernacki, "Method and Metaphor after the New Cultural History," in Beyond the Cultural Turn (Berkeley: University of California Press, 1999), 62-63. On definitions of the "New Cultural History of Education" see Antonio Novoa, "Texts, Images, Memories: Writing New Histories of Education," in Popkewitz, et al., eds., Cultural History and Education: Critical Essays on Knowledge and Schooling (New York, 2001), 45-66, and Julia Varela, "Genealogy of Education: Some Models of Analysis," ibid, 116.

4. J. M. Opal, "Exciting Emulation: Academies and the Transformation of the Rural North, 1780s-1820s," Journal of American History (2004): 445-470; Richard Bushman, Refinement of America: Persons, Houses, Cities (New York, 1992), xvii-xix, 61-99.

5. On "demand" as a phenomenon to be explained, see: Cary Carson, "The Consumer Revolution in Colonial British America: Why Demand?" in Cary Carson, Ronald Hoffman, and Peter J. Albert, eds., Of Consuming Interests: The Style of Life in the Eighteenth Century (Charlottesville, 1994), 483697. That the lower south was deeply status conscious and "negotiated" is well-established, see: Joyce Chaplin, An Anxious Pursuit: Agricultural Innovation and Modernity in the Lower South, 1740-1815 (Chapel Hill, NC, 1993), 26-29, 92-93, 106-128; Jack P. Greene, Pursuits of Happiness: The Social Development of Early Modern British Colonies and the Formation of American Culture (Chapel Hill, NC, 1988), 124-151, especially 145-151; Timothy James Lockley, Lines in the Sand: Race and Class in Lowcountry Georgia, 1750-1860 (Athens, GA, 2001), xiii-xv, 113; Claudio Saunt, A New Order of Things: Property, Power, and the Transformation of the Creek Indians, 1733-1816 (Cambridge, 1999); Philip D. Morgan, Slave Counterpoint: Black Culture in the Eighteenth-Century Chesapeake and Lowcountry (Chapel Hill: University of North Carolina Press, 1998); Theda Perdue, Cherokee Women: Gender and Culture Change, 1700-1835 (Lincoln, NB, 1998), chapters 3, 5, and passim; Peter Wood, Black Majority: Negroes in Colonial South Carolina from 1670 through the Stono Rebellion (New York: Norton, 1974).

6. South Carolina Gazette, May 21, 1750, August 24, 1752 (Sheed's school continued), December 6, 1760 (advertising dry goods and rum for sale), and January 24, 1761 (schooling again); South Carolina Gazette, February 19, 1750 (Dymond's school) and October 23, 1752 (Dymond advertises for boarders); Georgia Gazette, June 3, 1767 (school closing); Georgia Gazette, May 17, 1775 (would-be classics instructor); South Carolina Gazette, November 27 
and December 18 1749; May 21, June 11, and November 12, 1750; December 24, 1751, October 16, 1752 (dancing school initiative).

7. This narrative of growth during the middle decades of the eighteenth century confirms that trends in New England and elsewhere had corollaries in the Lower South (Georgia and South Carolina): E. Jennifer Monaghan, Learning to Read and Write in Early America (Boston, 2005), 143-153, 191-193. Sharon Braslaw Sundue, "Confining the Poor to Ignorance? Eighteenth Century American Experiments with Charity," History of Education Quarterly 47 (May 2007): 123-148; Thomas Woody, History of Women's Education in the United States, 2 vols (New York, 1929), vol. 1, 229-233, 301-302 as cited in Nash "Rethinking," 173 n.6; McCaul, "A Documentary History of Education in Georgia," 143, 147. Elizabeth Clark has argued for a return to thinking about theory, particularly a re-evaluation of postcolonial studies and Gabrielle Spiegel's "social logic of the text." See Clark, History, Theory, Text: Historians and the Linguistic Turn (Cambridge, MA, 2004), 162-165, 178, 181-185. I pull the concept of "incitement" from Michel Foucault, The History of Sexuality, Volume 1: An Introduction (New York, 1978), 92-95. A wonderfully distinctive application of Foucault is Stephanie Smallwood, Saltwater Slavery (New York, 2007), 35-36, 217 n.6.

8. South Carolina Gazette, April 1, April 22, August 19, and December 9, 1732, and March 17, May 19, June 16, and July 14, 1733. The numbers represented here are from Georgia and South Carolina newspapers and archival sources: Spady, “'Like the Spider from the Rose': Colonial Knowledge Competition and the Origins of Non-elite Education in Georgia and South Carolina, 1700s-1820s," (Ph.D. diss., College of William and Mary, 2006), appendix.

9. South Carolina Gazette, February 16, 1740; February 13, 1742; December 24, 1753; February 26, 1741; October 22, 1750; October 7, 1751; March 8, 1760; December 30, 1760; August 6, 1760; September 28, 1765; May 21, 1750; August 24, 1752; December 6, 1760; and January 24, 1761.

10. South Carolina Gazette, September 23, 1751, November 13, 1751, January 6, 1757, February 18, 1764, March 7, 1774, and February 13, 1775.

11. For some of the Besselieu ads see: South Carolina Gazette, August 18, September 22, and December 15, 1746; January 5, 1747; October 10, 1754; and January 30, 1755. Woodin family members advertised beginning in 1764: South Carolina Gazette October 22, 1764, June 29, 1767 (Elizabeth, Rebecca and Thomas Woodin).

12. South Carolina Gazette, June 15, 1767; South Carolina Gazette, November 13, 1751 (boarding school reference). South Carolina banned teaching slaves to write after the Stono Slave Rebellion in 1739; Georgia followed suit in 1755: J. Easterby, ed., Journal of the Commons House of Assembly, September 12, 1739-March 26, 1741 (Columbia, SC, 1952).

13. Georgia Gazette, January 5, 1774 (speedy improvement promised); for another ad promising "improvement" see South Carolina Gazette, February 2, 1767 ("morals and improvement"); South Carolina Gazette and Country Journal, March 1, 1774. ("sobriety" and "good disposition"). Another type of ad revealing the construction of educational demand and a market would be ads for occasional lectures, such as one offered by "Mr. Anderson" and advertised in The South Carolina Gazette in 1739.

14. Georgia Gazette, August 2, 1769 (Bedon); Johnson's register is a newly discovered document. William Johnson, "Charleston School Register, 1767-1768," South Carolina State Museum, Columbia South Carolina. I am indebted to 
Fritz P. Hamer for the attribution and his identification of the connection to Johnson's ad: South Carolina Gazette, October 5, 1767.

15. Notebook, March 21, 1760, Huger Family Papers, box/file 30-9-8, South Carolina Historical Society, Charleston, South Carolina.

16. South Carolina Gazette, December 10, 17, 1772.

17. A femme sole trader was a woman empowered to conduct trade on her own account, not strictly under the control of a husband. Georgia Gazette, May 27, 1767 (Stevens teaching music in Savannah); City Gazette and Daily Advertiser, January 1, 1795 ("Mrs. Cogdell" teaching needlework and etc. in Charleston). See also Wendy Gonaver, "Race Relations: An Inter-racial Family in Early America" (MA Thesis, College of William and Mary, 2001), 29. I am grateful to Gonaver for the citations to the John Stevens family that follow.

18. John Stevens to Benjamin Yarnold in London, Charleston, SC, December 18, 1769: Stevens/Cogdell-Sanders/Venning Papers. Library Company of Philadelphia. BI, fol. 2. Gonaver, "Race Relations," 28.

19. John Stevens to James Mathias of Warnford Court near the Royal Exchange in London, Charleston, SC, December 18, 1769. Stevens/Cogdell-Sanders/ Venning Papers. Library Company of Philadelphia. BI, fol. 2. Gonaver, "Race Relations," 25-29.

20. James Habersham to Lady Huntington, Savannah, December 31, 1770, Chestnut College Collection, MS 1130, Georgia Historical Society. On the power of such elite fathers in a slave society and the importance of sentiment in familial relations see: Sarah M.S. Pearsall, "The late flagrant instance of depravity in my family:' The Story of an Anglo-Jamaican Cuckold," WMQ 3rd Ser., 60, no. 3 (2003): 574-581. Gonaver, "Race Relations," 28. For other letters of Habersham supervising his and other children's education closely, see: James Habersham to Benjamin Franklin, Savannah, July 14 1764, and James Habersham to William Russell [in London], Savannah, October 10, 1764, and John Clark to James Habersham, London, August 3, [date torn], James Habersham Papers (1756-1775), Folder 1, Folder 18, GHS. These letter are also published in Collections of the GA Historical Society: The Letters of the Honorable James Habersham, v.6)

21. "Paul Cross Word List" and Cross to "Dear Sir," n.d., River Riopongo, Windward Coast, Paul Cross Papers, fol. 4. South Caroliniana Library, University of South Carolina; Bushman, Refinement of America, 61-99; Opal, 456-468.

22. Robert Olwell, Masters, Slaves, and Subjects: The Culture of Power in the South Carolina Low Country, 1740-1790 (Ithaca, NY, 1998), 166-178; Betty Wood, Women's Work, Men's Work: The Informal Slave Economies of Lowcountry Georgia (Athens, 1995), 81-83; Douglas R Egerton, He Shall Go Out Free: The Lives of Denmark Vesey (Wisconsin, 2000), 68-69.

23. Paul Cross Papers, fol. 4. South Caroliniana Library. Paul Cross to "Dear Sir," [n.d.], River Riopongo, Windward Coast. Paul Cross Papers, fol. 4. South Caroliniana Library.

24. South Carolina Gazette, January 25, 1770; Georgia Gazette, March 2, 1774; Richard Walsh, Charleston's Sons of Liberty: A Study of the Artisans, 17631789 (Columbia, SC, 1959), 30, 91, 133-134.

25. South Carolina Gazette, April 30, 1763, January 26, 1767, September 28, 1769, and September 3, 1772. Walsh, Charleston's Sons of Liberty, 31 n.11, 117.

26. Resolution of the Committee of the House of Commons, Egmont mss., vol. 14213, 1-2; Verelest to Oglethorpe, Westminster, August 11, 1738, Egmont 
mss., vol. 14209, 143, 149; Verelest to Causton, Westminster, August 11, 1737, Egmont mss., vol. 14209, 18; George C Rogers, Charleston in the Age of the Pinckneys (Columbia, SC, 1980), 97-98; William T. Bull to SPG, South Carolina, October 10, 1721, Gertrude Foster, ed., "Documentary History Documentary History History of Education in South Carolina as Revealed in the Manuscripts of the Society for the Propagation of the Gospel in Foreign Parts," (Ed.D., University of South Carolina, 1932), 3: 352-355; Tim Millencamp to Rev. Dr. Bearcroft, St James Goose Creek, April 12, 1743, Foster, ed., "Documentary History," 5: 704, 1: 169-193; Thomas Hassell to Secty [SPG], March 25, 1734, Foster, ed., "Documentary History," 5: 659; Thomas Cooper and David McCord, eds., The Statutes at Large of South Carolina: Edited under Authority of the Legislature, vol. 8 (Columbia, SC, 1837), 106, 110-112, 347; George Fenwick Jones, The Georgia Dutch: From the Rhine and Danube to the Savannah, 1733-1783 (Athens: University of Georgia Press, 1992), 63-65, 243; Henry Smith, "The Town of Dorchester, in South Carolina-A Sketch of Its History," SCHM 6 (April 1905): 93-95; James O'Neil Spady, "Bubbles and Beggars and the Bodies of Laborers: The Georgia Trusteeship, White Labor, and the Cultural Politics of Colonialism," in L. H. Roper and Bertrand Van Ruymbeke, eds., Constructing Early Modern Empires: Proprietary Ventures and the Origins of the Atlantic World, 1500-1750 (Boston: Brill, 2007), 213-268.

27. Georgia Gazette, March 16, 1774 (union society); Allen Candler, comp., The Colonial Records of the State of Georgia, 1732-1782, vol. 21 (Atlanta, 1904-1916), 221-223 (Savannah Indian missionary school); William T. Bull to SPG, South Carolina, October 10, 1721, Foster, "Documentary History," 3: 352-355; Tim Millencamp to Rev. Dr. Bearcroft, St James Goose Creek, April 12, 1743, Foster, ed., "Documentary History," 5: 704, 1: 169-193; Thomas Hassell to Secty [SPG], March 25, 1734, Foster, ed., "Documentary History," 5: 659; Cooper and McCord, eds., The Statutes at Large of South Carolina; Charles Woodmason, Carolina Backcountry on the Eve of the Revolution: The Journal and Other Writings of Charles Woodmason, Richard James Hooker, ed. (Chapel Hill, NC, 1953), 71-72; Jones, The Georgia Dutch, 63-65, 243; Resolution of the Committee of the House of Commons, Egmont mss., vol. 14213, 1-2; Verelest to Oglethorpe, Westminster, August 11, 1738, Egmont mss., vol. 14209, 143; Verelest to Whitefield, Westminster, August 11, 1738, Egmont mss., vol. 14209, 149; Verelest to Causton, Westminster, August 11, 1737, Egmont mss., vol. 14209, 18; Rogers, Charleston in the Age of the Pinckneys, 97-98.

28. Helen Livingston, "Thomas Morritt: Schoolmaster at the Charleston Free School, 1723-1728," Historical Magazine of the Protestant Episcopal Church 14 (1946): 158-159; Edgar Legare Pennington, "The Reverend Thomas Morritt and the Free School in Charleston," SCHM, 32 (January 1931), 34-45.

29. Ann Laura Stoler, Race and Education of Desire: A Colonial Reading of Foucault's History of Sexuality (Durham, 1997), 13-16; Mary Louise Pratt, Imperial Eyes: Travel Writing and Transculturation (New York, 1992), 29-37; Chaplin, An Anxious Pursuit, 23-65, 134-158

30. Wesley, Journal, 182.

31. John Wesley quoting and adapting Ovid's Metamorphoses from memory, Georgia, October 1736, in The Journal of the Reverend John Wesley, Nehemiah Curnock, ed, vol. 1 (New York, 1909), 284, n.1

32. John Wesley to Sophy Hopkey, [Savannah], February 6, 1737 in Telford, ed., Letters of John Wesley, 211. 
33. John Wesley to Sophy Williamson, Savannah, July 5, 1737 in Telford, ed., Letters of John Wesley, 224-225. Kenneth Lockridge, On the Sources of Patriarchal Rage (New York, 1992) argues that such outbursts and anger could turn into rage and that rage was a pathological feature of gendered power for gentry men of the eighteenth century. My argument is about surveillance and power, not psychology. Wesley was in accord with the Georgia authorities, who once considered a proposal that daughters of colonists "marry persons approved of by us" and who decided to allow daughters to inherit land only if they married men who promised to live in the colony: Egmont, Journal, 96, 340.

34. John Wesley to Sophia [Hopkey] Williamson, Savannah, August 11, 1737 in Telford, ed., Letters of John Wesley, 226.

35. John Wesley to Sophy Williamson, Savannah, July 5, 1737 in Telford, ed., Letters of John Wesley, 224-225.

36. Ibid.

37. Wesley, Journal, 182. On the Franke Institution at Halle, see: Franke, Pietas Hallensis ... translated and extracted in George Whitefield, A Continuation of the Account of the Orphan House in Georgia . . . (London, 1743), 102; The first English translation and printing of Franke's memoir is Augustus Hermann Franke, Pietas Hallensis: Or a Public Demonstration of the FootSteps of A Divine Being Yet in the World . . . (London, 1705). The 1705 edition has a bibliography of the books printed by the institution to that date beginning on page 145. Gustav Friedrich Herkberg, August Hermann Franke und sein hallisches Waisenhaus (Halle, 1898), the quoted passage on praktische Christentums is on page 32. My discussion of Ebenezer complements and supports the work of Renate Wilson, especially Renate Wilson, "Halle and Ebenezer: Pietism, Agriculture, and Commerce in Colonial Georgia," (Ph.D. diss., University of Maryland, 1988). See also Wilson, Pious Traders in Medicine: A German Pharmaceutical Network in Eighteenth Century North America (University Park, Pennsylvania, 2000), chapter one, esp. 22-25.

38. Georgia at first helped orphans solely by assigning guardians in court, as was the practice in England. Some guardians may have mistreated or neglected their charges, as in one case where a girl was found in bed with several men in her guardian's house. Clarke, The Case of Orphans Consider'd, from Antiquity: with Some Remarks on Our Courts of Wards . . (London, 1725), passim. Thomas Christie to Trustees, Savannah, May 28, 1735, Egmont mss typescript v.14200, pt.2, p. 139. Causton to Oglethorpe, Savannah, March 24, 1735, Egmont mss typescript, v.14200, pt. 2, pp. 280-281. Clyde Buckingham, "Early American Orphanages: Ebenezer and Bethesda," Social Forces 26 (1948): 312-321. Orphanages first emerged in market towns in Europe and England during the fifteenth and sixteenth centuries. See: Anne E. C. McCants, Civic Charity in a Golden Age: Orphan Care in Early Modern Amsterdam (Chicago, 1997), esp. chs. 1 and 2; Thomas Max Safley, Charity and Economy in the Orphanages of Early Modern Augsburg (Atlantic Highlands, NJ, 1997); Carol Kazmieczak Manzione, A Passing Charity: Christ's Hospital of London, 1552-1598 (London, 1995). Franke, Pietas Hallensis, 104. On Franke's blend of evangelicalism and discipline see also Anthony J. La Vopa, Grace, Talent, and Merit: Poor Students, Clerical Careers, and Professional Ideology in Eighteenth-Century Germany (Cambridge, 1988), 146-155. Franke, Pietas Hallensis, 103-105. George Fenwick Jones and Marie Hahn, eds., Detailed Reports on the Salzburg Emigrants who Settled in America . . . Samuel Urlsperger, ed., vol. 3, 1736 (Athens, GA, 1972), 17 (n. 43, 44), 178. Jones and Hahn, eds., Detailed Reports on the Salzburg 
Emigrants, 7-8. William Albert Hansen, "John Wesley and the Rhetoric of Reform," (Ph.D. diss., University of Oregon, 1972).

39. Jones and Hahn, eds., Detailed Reports on the Salzburg Emigrants, 207. Georgia historians have occasionally debated whether Bethesda or Ebenezer should be considered the "first" orphanage in Georgia. George Fenwick Jones, The Georgia Dutch, generally emphasizes the Ebenezer Orphanage's priority, while Edward Cashin, in his more recent Beloved Bethesda, has downplayed Ebenezer, suggesting an independent origination for Bethesda. Both scholars are right. Ebenezer was first and Bethesda was not entirely a derivation of the Ebenezer initiative. But they also have common origins, especially at the level of inspiration.

40. Wesley, The Journal of the Reverend John Wesley, A.M., 142, 218 (translating German), 181 (Bolzius and Gronau visit from Ebenezer), 271-272 (Von Reck visit from Ebenezer September 8-20, 1736), 274 (visits to Ebenezer noted).

41. Jones and Hahn, eds., Detailed Reports on the Salzburg Emigrants, 2-3. Anonymous, “The State of Ebenezer, June 1738," Egmont v.14203, pt.2 p. 111.

42. Jones and Hahn, eds., Detailed Reports on the Salzburg Emigrants, 6.

43. George Fenwick Jones, "Two 'Salzburger' Letters from George Whitefield and Theobald Keifer II," GHQ 62 (1978): 50-57.

44. Although, in his published memoir, Whitefield claimed that the idea for the Bethesda Orphanage "was first proposed to [him] by my dear Friend the Rev'd Mr. Charles Wesley," John Wesley is a more likely source. Whitefield, A Further Account of God's Dealings with the Reverend Mr. George Whitefield . . . to which is Annex'd a Brief Account of the Rise, Progress, and Current Situation of the Orphan-House in Georgia in a Letter to a Friend (Philadelphia, 1746), 51. Whitefield had motivations to snub John. He and John Wesley disagreed, sometimes publicly, on issues such as the relationship between the Anglican and Methodist doctrines as well as slavery: see Samuel J. Rogal, John and Charles Wesley (Boston, 1983), 76. John Wesley to George Whitefield, Savannah, September 10, 1736 in John Telford, ed., The Letters of the Rev. John Wesley, A.M . . ., Vol 1. (London, 1931), 204206. On Whitefield's fundraising see: Frank Lambert, "Pedlar in Divinity': George Whitefield and the Great Awakening, 1737-1745," Journal of American History (December 1990): 812-837; Thomas P. Haviland, "Of Franklin, Whitefield, and Orphans," GHQ 29 (December 1945): 211-216; Robert L. McCaul, "Whitefield's Bethesda College Projects and Other Major Attempts to Found Colonial Colleges," GHQ 44 (December 1960): 381-398; George Whitefield to Herman Verelst, Savannah, January 16, 1740, Whitefield to Verelst, Savannah, January 28, 1740, Whitefield to the Trustees, Savannah, March 10, 1740, and Whitefield to the Trustees, Savannah, April 7, 1740, in Lane, ed., Oglethorpe's Georgia, 433-441. "Report from the Orphan House" June 4, 1740, Oglethorpe's Georgia, Lane, ed., vol. 2, 437-440. George White, ed., Historical Collections of Georgia . . . (New York: Pudney and Russell, 1854), 332-333.

45. "Report from the Orphan House" June 4, 1740, Oglethorpe's Georgia, Lane, ed., vol. 2, 437-440; Samuel Fayrweather to Rev Thomas Prince and Rev Thomas Foxcroft, Bethesda, May 25, 1748, Samuel Fayrweather letter and notes, MS 249, Georgia Historical Society, Savannah, Georgia. Whitefield, Further Account of God's Dealings, 58; "Floor Plan of Mr. Whitefield's House" [n.d.] Chestnut College Collection, MS 1130, Georgia Historical Society. James Habersham to Lady Huntington, Savannah, June 5, 1771, 
Chestnut College Collection, MS 1130, GHS. "Rules and orders for daily and annual schedules for 'Bethesda College,'" n.d. [anon but attributed to Whitefield himself], Chestnut College Collection, MS 1130, GHS: the rules throughout distinguish between orphans and students, such as "orphans and students" or "Orphan or Student." On every Dec 27 there is to be a "Founders Day" commemoration (Whitefield's birthday): the order of speakers goes first from orphans speaking to "orphans or students" to a closing with "an application, Exhortation, and prayer by the Master of the College." The orphans were prescribed the topic on the mercy of God in providing "Habitation and places of Education for poor Orphans-In thee the Fatherless find Mercy." Evidence suggests the social and academic curriculum had at least some of the desired effects. During the initial six-year period, 1739-1745, 86 children, both boys and girls, lived at Bethesda. Sixty-two of the children were eventually bound out or married: White, ed., Historical Collections of Georgia . . .; Martha Gallaudet Waring, "Savannah's Earliest Private Schools, 1733-1800," GHQ 14 (December 1930): 41-57; McCaul, "Whitefield's Bethesda College Projects and Other Major Attempts to Found Colonial Colleges,", 263-277. In other colonies, orphan courts and parish vestries accomplished the task of orphan care through binding out: James Horn, Adapting to a New World: English Society in the Seventeenth-Century Chesapeake (Chapel Hill, NC, 1994), 216; Lois Green Carr, "The Development of the Maryland Orphan's Court," in Law, Society and Politics in Early Maryland, Aubrey C. Land, Lois Green Carr, and Papefuse, eds. (Baltimore, 1977), 41-56; Alan D. Watson, "Orphanages in Colonial North Carolina: Edgecombe County as a Case Study," North Carolina Historical Review 52 (1975): 105-119. On early modern European models see McCants, Civic Charity in a Golden Age; Safley, Charity and Economy in the Orphanages of Early Modern Augsburg; Manzione, A Passing Charity: Christ's Hospital of London, 1552-1598, which describes the hospital as a general orphanage, school, and pauper refuge that took in fatherless children and children whose fathers were poor; Philip Gavitt, Charity and Children in Renaissance Florence: The Ospedale degli Innocenti, 1410-1536 (Ann Arbor, MI, 1990), which outlines how the silk guild and the commune of Florence collaborated to found and run the institution after 1419. For orphan institutions in rival empires see: Emily Clark and Virginia Meacham Gould, "The Feminine Face of Afro-Catholicism in New Orleans, 1727-1852," William and Mary Quarterly 59, no. 2 (2002): 409-449; Asuncion Lavrin, Sexuality and Marriage in Colonial Latin America (Lincoln, NE, 1989), 139, 228, 305; Timothy Coates, Convicts and Orphans: Forced and State-Sponsored Colonizers in the Portuguese Empire, 1550-1750, vol. 16 (Stanford, CA, 2001), 126-134.

46. E. Jennifer Monaghan, Learning to Read and Write in Colonial America: Literacy Instruction and Acquisition in Cultural Context (Amherst, MA, 2005), 201-202. Livingston, "Thomas Morritt: Schoolmaster at the Charleston Free School, 1723-1728,"; Pennington, "The Reverend Thomas Morritt and the Free School in Charleston,".

47. South Carolina Gazette, February 16, 1740; October 22, 1750; March 8, 1760; December 30, 1760; August 6, 1760; December 6, 1760; and January $24,1761$.

48. Georgia Gazette, June 29, 1768; Saunt, New Order of Things, 186-187.

49. Cooper and McCord, Statutes at Large of South Carolina, vol. 8, n. 554. "Childberry School Minutes, 1750-1754," August 1, 1750, South Caroliniana Library. Tim Millencamp to Revd. Dr. Bearcroft, St James Goose Creek, April 12, 1743 in Foster, "Documentary History," vol. 5, 704; Jas. Habersham 
to Daniel Burton, St. James Goose Creek, October 14, 1768, ibid., 818-820a; and ibid., vol. 1, 169-193; "Childberry School Minutes, 1750-1754," July 2, 1752, November 8, 1752, November 24, 1753, South Caroliniana Library, Columbia, South Carolina; Cooper and McCord, South Carolina Statutes at Large, vol. 8, 110-112, 192, 347; Journal of the Society for the Relief of the Widows and Orphans of the Clergy of the Protestant Episcopal Church in South Carolina from April 1762 to October 1813 (Charleston, 1813); Spady, "Bubbles and Beggars," 251-257.

50. Minutes of the Dorchester Free School Board, 1757-1819, Daniel J. Bell, transcription (South Carolina Department of Archives and History, 1998), $1-2,3,13$.

51. John Percival Egmont, The Journal of the Earl of Egmont: Abstracts of the Trustees Proceedings for Establishing the Colony of Georgia, 1732-1738, Robert G. McPherson, ed., vol. 217 (Athens, GA, 1962), 236-237; Livingston, "Thomas Morritt," 158-159. On "environmentalism" and racial theory see: Bernard Sheehan, Seeds of Extinction: Jeffersonian Philanthropy and the American Indian (Chapel Hill, NC, 1973), 19-26 and Joyce E. Chaplin, "Natural Philosophy and an Early Racial Idiom in North America: Comparing English and Indian Bodies," WMQ, 3rd ser., 54, no. 1 (1997): 229-252.

52. South Carolina Gazette, November 13, 1751; Charles Woodmason to John Chestnut, June 30, 1769, in Hooker ed., Carolina Backcountry, 136-161.

53. South Carolina Gazette and Country Journal, July 28, 1767; South Carolina Gazette and Country Journal, November 18, 1766. Adair, 368; Atkin, 81; "A Gurnal of my Traveling to the Indian Cuntray. I left augustay the 10th October 1767," Georgia Historical Society. Journal 1767 (typescript copy). Collection 10. Sweet, Negotiating for Georgia, 99-105; Chaplin, Anxious Pursuit, 8-10, 281-282; Rachel Klein, Unification of Slave State, 33-34. Richard Maxwell Brown, The South Carolina Regulators (Cambridge, MA, 1963), 34-37, 38-40.

54. Charles Woodmason to John Chestnut, June 30, 1769, in Hooker ed., Carolina Backcountry, 136-161 (quotes pp. 118-119); J. H. Easterby, "The South Carolina Education Bill of 1770," SCHM 48 (1947): 95-111. Brown, The South Carolina Regulators; Klein, Unification of a Slave State, 47-51, 63-64.

55. Woodmason, 120-121.

56. Ibid.

57. Ibid., 121.

58. Ibid., 121-122.

59. Ibid., 226. See also Records of the Library Society and Winyah Indigo Society (Georgetown, SC), South Caroliniana Library, University of South Carolina.

60. The Georgia Gazette, May 25, 1768, May 31, 1769, February 21, 1770, and April 18, 1770. Easterby, "South Carolina Education Bill of 1770," 107; Parliament funded several schools directly: McCaul, "Education in Georgia: Financial Support . . .," 105-109.

61. Hammerer followed the Reverend John Martin, who had traveled to the Overhills Cherokee in 1757 to begin a Christian mission. Martin had preceded the Reverend William Richardson. John Daniel Hammerer, An Account of a Plan for Civilizing the North American Indians: Proposed in the Eighteenth Century, Paul Leicester Ford, ed. (Brooklyn: Historical Printing Club, 1890). Samuel C. Williams, "Christian Missions to the Overhill Cherokees," Chronicles of Oklahoma 12, no. 1 (March 1934): 67-70; S. C. Williams, "Presbyterian Mission to the Cherokees, 1757-59," Tennessee Historical Magazine 1 (N. S.): 125. Williams, "Christian Missions to the Overhill Cherokees,". 
62. Edmund S. Morgan, American Slavery, American Freedom: The Ordeal of Virginia (New York, 1975), 316-387.

63. Dana Nelson, "Consolidating National Masculinity," in Blair St. George, ed., Possible Pasts, 201-202 ("civilization project" quote). Opal, "Exciting Emulation," 445-470.

64. An Impartial Enquiry into the State and Utility of the Province of Georgia (London, 1741) in Trevor R. Reese, ed., The Clamorous Malcontents: Criticisms and Defenses of the Colony of Georgia, 1741-1743 (Savannah, 1973), 170 (freeholders); St. Andrews Parish Resolves, Georgia, January 12, 1775 as quoted in Betty Wood, Slavery in Colonial Georgia (Athens, GA, 1984), 201 (Revolution era committee).

65. Lockley, Lines in the Sand, 129 and passim chapter four.

66. Sundue, Industrious in their Stations; Nelson, "Consolidating National Masculinity,"; Chaplin, An Anxious Pursuit. Sally Hadden, Slave Patrols: Law and Violence and the Carolinas (Cambridge, 2001), 73, has argued that the slave patrol was a cross-class and elite-led endeavor-a similar pattern is found in, for example, charity schools. Apprenticeship ads probably attracted parents and guardians of all statuses seeking to place children in line for instruction in a trade. For a selection see: South Carolina Gazette, July 14, 1739, April 28, 1746, January 1, 1750, January 6, 1757, March 6, 1762; August 2, 1969; September 28, 1769; Georgia Gazette, June 8, 1768, May 4, 1774, June 7, 1775.

67. Jefferson to Colonel Charles Yancey, Monticello, January 6, 1816, The Works of Thomas Jefferson, Volume 11, Paul Leicester, ed. (New York, 1905), 497. David Roediger briefly discusses this binary opposition in the context of Native American interactions with whites in The Wages of Whiteness: Race and the Making of the American Working Class (New York, 1991), chapter one (see esp. 19, 21, 23).

1.George Washington, "Circular to the State Governments Newburgh, June 8, 1783," in Joseph Rhodehamel, comp., George Washington: Writings (Library of America: New York, 1997), 517.

2. Calhoun to House of Representatives, December 5, 1818 in Green, Removal, 46.

3. Robert G. Parkinson, The Common Cause: Creating Race and Nation in the American Revolution (Chapel Hill, NC, 2016), 459. John Shy, A People Numerous and Armed: Reflections on the Military Struggle for American Independence (Ann Arbor, MI, 1990), 166. "Convention between South Carolina and Georgia concluded at Beaufort in 1787," in Watkins Robert and George Watkins, ed. and comp., Digest of the Laws of the State of Georgia ... (Philadelphia, 1800), 752-755. Woody Holton, Forced Founders: Indians, Debtors, Slaves, and the Making of the American Revolution in Virginia (Chapel Hill, NC, 1990), ch. 5 (passim); David Roediger, Wages of Whiteness: Race and the Making of the American Working Class (New York, 1991), 19-40 and 43-64. Ramsay to Benjamin Rush, Charleston, July 11, 1783 in Robert H. Brunhouse, ed., David Ramsay, 1749-1815, Transactions of the American Philosophical Society 55 (1965): 75. See also Barbara Bellows, Benevolence among Slaveholders: Assisting the Poor in Charleston South Carolina, 1670-1860 (Baton Rouge, LA, 1993).

4. Parkinson, The Common Cause; Shy, A People Numerous and Armed.

5. On "social citizenship," I am less interested in the details for debates among sociologists and historians about the functionalist limitations of the theory. The point is to see how poorer whites gained access to citizenship privileges that colonized people-even free black people-were denied. See Beatrice McKenzie, "Gender and United States Citizenship in Nation and Empire," 
History Compass 4, no. 3 (2006): 592-602; Erika Lee, At America's Gates: Chinese Immigration during the Exclusion Era, 1882-1943 (Chapel Hill, NC: University of North Carolina Press, 2003).

6. Andy Green, Education and State Formation: Europe, East Asia and the USA (London, 2013), 170-173.

7. Sylvia Frey, Water from the Rock: Black Resistance in a Revolutionary Age (Princeton, NJ, 1991), 108-142; Colin Calloway, The American Revolution in Indian Country: Crisis and Diversity in Native Communities (New York: Cambridge University Press, 1995), 26.

8. Frey, Water from the Rock, passim; "Papers of the Second Council of Safety," 205-206, as cited in William S Willis, "Divide and Rule: Red, White and Black in the Southeast," The Journal of Negro History 48, no. 3 (July 1962, 1970): 170 .

9. Georgia Gazette (Savannah), December 7, 1774, as quoted in Frey, Water from the Rock, 54 (1774 uprising); Papers of Henry Laurens, 10: 206-208, 231-232 as quoted in Frey Water from the Rock, 61-62 (1776 uprising).

For more on the maroon camp: "Savannah April 26," Gazette of the State of Georgia, April 26, 1787: a battle between runaways and South Carolina militia and Catawba Indians. "Savannah May 10," Gazette of the State of Georgia, May 10, 1787: attack upon a maroon camp in Patton's Swamp by South Carolina and Georgia militia and 15 Catawbas. "Savannah, May 17," Gazette of the State of Georgia, May 17, 1787: Maroon camp near Savannah was broken up and runaways were surrendering daily.

Frey, Water from the Rock, 139-141 (John Cruden), 174 (estimates of freed people), 226-227 (ongoing slave rebellion). Sylvia Frey claims as many as 20,000 enslaved people from Georgia and South Carolina won their freedom at the close of the Revolution, sailing off with the Royal Navy. More conservative estimates must admit the approximately 5,000 the British documented taking with them when they left Charleston in 1782. Robert Olwell has claimed, plausibly, that maybe $80 \%$ of these documented slave refugees continued as slaves of Loyalists in Jamaica or East Florida. Many had been captives employed as plantation workers to supply the British army and navy-a status probably not significantly different from slavery. Olwell cites Joseph W. Barnwell, "The Evacuation of the British in 1782," SCHM 11 (1910): 26.

10. Manisha Sinha, The Slave's Cause: A History of Abolition (New Haven: Yale University Press, 2016), 34-85. James McMillin, The Final Victims: Foreign Slave Trade to North America, 1783-1810 (Columbia, SC, 2004), 47-48. On attitudes regarding the Yazoo land speculation scandal in the region, see: Hawkins to Dearborn, Hopewell on Keowee, November 22, 1796, in Letters of Benjamin Hawkins: 1796-1806, Stephen B. Weeks, ed., Collections of the Georgia Historical Society, vol. 9 (Savannah: Georgia Historical Society, 1916), 14; and McGillivray to Panton, Little Tallassie, 8 May 1790, in Caughey, McGillivray, 62, 159, 259. Spencer B. King, Jr., Georgia Voices: A Documentary History to 1872 (Athens: University of Georgia Press, 1966), 117. Georgia's white population grew from 102,261 in 1800 to 189,570 in 1820 , meaning the proportion of African Americans was growing.

11. History of the Baptist Denomination in Georgia (Atlanta: Harrison \& Co., 1881), 130. Alfred W. Pierce, A History of Methodism in Georgia (Atlanta: North GA Conference Historical Society, 1956), 88.

12. Roedigger, Wages of Whiteness, 55-58.

13. Ibid., 57. 
14. Robert Alderson, “Charleston's Rumored Slave Revolt of 1793," in David Geggus, ed., The Impact of the Haitian Revolution on the Atlantic World (Columbia, SC, 2001), 93-111; Frey, Water, 224-242.

15. Francis Gilmer Notebook and Journal, 1815-1822, Duke University Special Collections.

16. Virginia rejected Thomas Jefferson's extensive proposals for statewide, publicly funded education in 1779. In 1810, Virginia established a fund for schools, but no actual schools. Virginia established statewide schools in the 1820s - at about the same time as Tennessee. Delaware's 1792 constitution mandated schools, but it took decades to put a system together. And North Carolina did not realize revolutionary-era proposals until 1839. See: Robert J. Taggart, Private Philanthropy and Public Education (London, 1998), 26.

17. The growth of schooling could not have been merely a function of the diffusion of information because the informational benefits of literacy seem to have been readily available to colonial-era English speakers through public reading and sharing of news. Adam Fox, Oral and Literate Culture in England, 1500-1700 (Oxford, 2000), 36-37, 409: Fox argued that reading aloud meant that none in England were entirely outside the ambit of print and manuscript, and in early England at least, reading aloud was the norm. As a result, early modern England was more literate than historians have yet accepted.

18. Frederick A. Salzillo, Jr., "Economic and Political Foundations of Educational Reform Activity in Georgia, 1830-1840," (MA Ed., Georgia State University, 1973), 33-35.

19. Timothy Pickering to George Washington, January 8, 1791, Pickering Papers LXI 164-165A as quoted in Sheehan, Extinction, 132; Elias Cornelius to Sally Cornelius, Litchfield, Conn., June 12, 1816, Elias Cornelius Papers, 1816-1829, Duke University Special Collections.

20. Knox to Governor William Blount [Tennessee,] April 22, 1792 as quoted in Prucha, American Indian Policy in the Formative Years (Lincoln: University of Nebraska Press, 1970), 41. Calhoun, "Report on the Indian Trade . . . to House of Representatives, December 8, 1818," The Works of John C. Calhoun, vol. 5 (New York: Appleton \& Company, 1855), 8-24 (p. 18 for quotes).

21. "An Act for Making Provision for the Civilization of the Indian Tribes Adjoining the Frontier Settlements," March 3, 1819, United States Statues at Large, 3: 516-517.

22. As quoted in Michael D. Green, The Politics of Indian Removal: Creek Government and Society in Crisis (Lincoln, NE, 1982), 55.

23. Calboun Papers, 2: 141, 124-125, 171, 336. Green, Removal, 48-50. Green suggests that this shift was a reaction to the success of the Civilization Program. However, the first moves in this policy shift, not supported by Monroe, were made by Jackson and Calhoun in the late 1810s, simultaneously with the passage of the Civilization Act of 1819 and the U.S. partnership with missionaries. Bernard Sheehan, Seeds of Extinction: Jeffersonian Philanthropy and the American Indian (Chapel Hill, NC, 1973), 119-120, 137, 143, 248249, 262, 266; R. Pierce Beaver, Church, State, and the American Indians (St. Louis, 1966); Robert Berkofer, Salvation and the Savage, 1787-1862 (Lexington, 1965); Douglas C. Wilms, "Cherokee Land Use in Georgia before Removal," in William L. Anderson, ed., Cherokee Removal: Before and After (Athens, GA, 1991), 1-28. On the rise of the removal faction see Ronald N. Satz, American Indian Policy in the Jacksonian Era (Lincoln, 1975), 1-6; 
Reginald Horsman, "American Indian Policy and the Origins of Manifest Destiny," University of Birmingham Historical Journal 11 (1968): 130-139.

24. Edward E. Baptist, The Half Has Never Been Told: Slavery and the Making of American Capitalism (New York, 2014), 246; Sven Beckert, Empire of Cotton: A Global History (New York, 2015), 102-105.

1.George Liele to unknown, Kingston, December 18, 1791, Journal of Negro History 1 (1916): 71-74.

2. The half-Creek is Alec Cornells. Just before this statement, the missionary had preached from Acts 7:34-43, which is a meditation on how the Israelites backslid to worship idols during the Exodus. After the service, the missionary suggested to Cornells, "if we could learn to speak their language we would like to acquaint all Indians with God's Word. Should they accept and believe, they might come to God after this life and live a blessed life in the hereafter." This quote was part of Cornells's answer. Johann Christian Burkhard, Partners in the Lord's Work: The Diary of Two Moravian Missionaries in the Creek Indian Country, 1807-1813, Carl Mauelshagen and Gerald H. Davis, trans. (Atlanta, 1969), 53.

3. Anon, "Nancy Ward, War Woman," Cherokee Quarterly 1, no. 4 (Fall 1997), n.p. (quote).

4. Francis Gilmer Notebook and Journal, 1815-1822, Duke University Special Collections.

5. Sven Beckert, Empire of Cotton: A Global History (New York, 2015), xv and passim. Homi K. Bhabha, "Signs Taken for Wonders," The Location of Culture (New York, 1994), 102-122; Gayatri Spivak, "Can the Subaltern Speak?" in Cary Nelson and Larry Grossberg, eds., Marxism and the Interpretation of Culture (Chicago, 1988), 271-313. Grey Gundaker, Signs of Diaspora, Diaspora of Signs: Literacies, Creolization, and Vernacular Practice in African America (New York, 1998), 96.

6. Hawkins to Benjamin Hawkins, Pleasantville, January 21, 1803. Hawkins Family Papers. Series 1: Correspondence. Subseries 1.1 (1770-1804). Folder 12. UNC-Chapel Hill, Southern Historical Collection.

7. Henry Timberlake, Memoirs of Lieut. Henry Timberlake ... (London, 1765), 76.

8. Jeremiah Evarts Diary, April 30, 1822, Erwin-Floyd Papers, GHS; James Stuart, Three Years in North America (New York, 1833), 2: 94, 99. Douglas C. Wilms, "Cherokee Land Use in Georgia before Removal," in Anderson, ed., Cherokee Removal: Before and After (Athens, GA, 1991). On page 7 the table shows that between 1809 and 1824 slave numbers grew from 583 to 1,277; gristmills 13 to 36 ; sawmills 3 to 13 ; plows 567 to 2,923 ; horses 6,519 to 7,683 ; and swine 19,778 to 46,732 .

9. Meigs to Maj. Lovely, Cherokee Station, Brownsville, GA, February 20, 1802, Return J. Meigs Papers, 1802-1814, DSC (quote). Adm Hodgson, Remarks during a Journey through North America . . . (Westport, CT, 1970 [1823]), 268-269 (the ratio of plows to households was 1:4). Theda Perdue, Cherokee Women: Gender and Culture Change, 1700-1835 (Lincoln, NB, 1998), 118, 127, and 224 n. 73. "An Act Making Provision for the Civilization of the Indian Tribes and for Preserving Peace on the Frontier," 30 March 1802, United States Statutes at Large, 2: 139-146. In general, the Civilization Program spread west and northwest from the Lower Creek and Cherokee towns closest to Hawkin's agency. Wilms, "Cherokee Land Use in Georgia before Removal," 7: a table shows that between 1809 and 1824 the number of slaves in the Cherokee Nation grew from 583 to 1,277; gristmills 
from 13 to 36 ; sawmills from 3 to 13 ; plows from 567 to 2,923; horses from 6,519 to 7,683 ; and swine from 19,778 to 46,732 .

10. September 7, 1804, "Diary," John MacKee Papers, Southern Historical Collection (Thompson quote). Both Sophia Durant and Mrs. Charles Weatherford (discussed earlier in this chapter) were sisters of Alexander McGillivray, himself a half-breed Scottish-Creek man born and raised in the Creek country and then educated in the Charleston Free School shortly before the Revolution. McGillivray supported the gender politics and economics of the "Civilization Program," and at one time used his connections to facilitate a sale of Sophia Durant's property on behalf of his brother-in-law over her objection. McGillivray opposed some plans for Georgia and U.S. expansion and supported others. See McGillivray to Panton, Little Tallassie, 8 May 1790, in Caughey, McGillivray, 259. See page 62 for Robert Durant and McGillivray background and page 159 for the sale of land over Sophia Durant's objection. John Pope, A Tour through the Southern and Western Territories of the United States (Richmond: John Dixon, 1792), 46-52; Another sister of McGillivray, Jeannet, had married Louis Milfort. Letters of Hawkins, 24 (Tarrapin quote). Scott Lyons describes such changes in life patterns as modern too: X-Marks: Native Signatures of Assent (Minneapolis, MN, 2010), 9-12. Felicity Donohoe, “'Decoying them Within': Creek Gender Identities and the Subversion of Civilization," in Gregory D. Smithers and Brooke M. N. Newman, eds., Native Diasporas: Indigenous Identities and Settler Colonialism in the Americas (Lincoln: University of Nebraska Press, 2014), 187-205; Perdue, Cherokee Women; Claudio Saunt, A New Order of Things: Property, Power, and the Transformation of the Creek Indians, 1733-1816 (Cambridge, 1999); Kathryn E. Holland Braund, Deerskins and Duffels: Creek Indian Trade with Anglo-America, 1685-1815 (Lincoln: University of Nebraska Press, 1996); and Wilms, "Cherokee Land Use in Georgia before Removal," 1-28. Michael D. Green, The Politics of Indian Removal: Creek Government and Society in Crisis (Lincoln, NE, 1982), 55 (McIntosh description in Augusta Gazette).

11. Hawkins owned and read Adair's History of the American Indians. He embraced rationalism and expanded rights and privileges for women and girls. And although trade was the central feature of his administration of the Civilization Program, he once expressed considerable resistance to "land jobbing not favorable to the peace of the Frontiers" and was unwilling to work with men too deeply implicated in aggressive speculation schemes. He supported the U.S. "Trade and Intercourse Act" of 1796, which established factors within the Creek and Cherokee nations and regularized the trade, forced traders to get licenses, and allowed Indians to request the expulsion of unwelcome or troublesome traders. Frequently at odds with Georgia authorities, Hawkins's tenure as Indian agent foreshadowed the state versus federal showdown over the policy toward the Creek and Cherokee that would culminate in Indian removal in the early 1830s. Benjamin Hawkins Papers, 1790-1813, Box 3 Folder 5, GHS (word translations). David Henley to James Robertson, Nashville, June 19, 1797, David Henley Papers, 1791-1817, Duke University Special Collections. Henley declares that he is credibly informed that "Hawkins has more influence in the Creek Nation than any have had before him" and that he was very "popular with the commonality." Hawkins to Chickasaws, from Camp near Nashville, May 21, 1797, Benjamin Hawkins Papers, 1790-1813, Box 1 Item 3, Georgia Historical Society: "You have heard of an attempt of Zachariah Cox and Co. to settle the bank of Tennessee, he came on to Knoxville ... and applied to us for permission to come and 
trade among you, but as he stated his object fully, and as I am informed that the Indians were not wiling he should be among them, as they looked on him as the precursor of those who are represented as grasping after their lands, that he was to make the first attempt to get possession and the rest were to follow with the train of ills so alarming to the Indians, I have not consented to indulge Mr. Cox with the permission he applied for." Hawkins came to believe that Indian "industry" had already "elevated" some Indians before he had even arrived, making them "civilized" though "unenlightened." $\mathrm{He}$ hoped that one day "the polished Virginian, as well as the untutored Creek, may hereafter ascend" to a higher stage of improvement: Letters of Hawkins, 57. See also: Hawkins Family Papers, Series 1: Correspondence. Subseries 1.1 (1770-1804), Southern Historical Collection, Folder 9 (Hawkins's speech in the Senate Chamber advocating Indian rights, February 10, 1792), Folder 10 (Hawkins orders provisions for a Creek woman named Hothletocco so she and her family can return to Cowetah, January 6, 1798), and Folder 11 (Affidavit, July 11, 1801, in which Hawkins intervenes on behalf of Creeks re: a disagreement with settlers about a stolen horse), and Fol. 12 (William Hawkins [nephew] to Benjamin Hawkins, Pleasant Hill, January 21, 1803 re: civilization program benefits for Indians interests against those hostile to their interests). For further evidence of Hawkins's opposition to land speculations: Hawkins to Dearborn, Hopewell on Keowee, November 22, 1796, in Letters of Benjamin Hawkins: 1796-1806, Stephen B. Weeks, ed., Collections of the Georgia Historical Society, vol. 9 (Savannah: Georgia Historical Society, 1916), 14. On Hawkins's support of federal regulation of the Indian trade: Henri, Hawkins, 94-95. On the life and career of Hawkins see also Merrit Pound, Benjamin Hawkins-Indian Agent (Athens, GA, 1951). Henri, Hawkins, 88. Lucy Eldersveld Murphy, "Autonomy and Economic Roles of Indian Women of the Fox-Wisconsin River Region, 1763-1832,” in Nancy Shoemaker, ed., Negotiators of Change: Historical Perspectives on Native American Women (New York, 1995), 72-89 (esp. 75-77). See also Kathryn E. Holland Braund, "Guardians of Tradition and Handmaidens to Change: Women's Roles in Creek Economic and Social Life during the Eighteenth Century," American Indian Quarterly 14 (1990): 239-258; and Carol Devens, Countering Colonization: Native American Women and Great lakes Missions, 1630-1900 (Berkeley, 1990). Braund, Deerskins \& Duffels, 185.

12. Letters of Benjamin Hawkins: 1796-1806, Stephen B. Weeks, ed., Collections of the Georgia Historical Society, vol. 9 (Savannah: Georgia Historical Society, 1916), 13. Joel W. Martin, Sacred Revolt: The Muskogee' Struggle for a New World (Boston: Beacon, 1991), 87-114 (esp 104-106).

13. The Moravian missionaries returned the grudging respect, regarding Hawkins as a decent person but not Christian enough. See Carl Mauelshagen and Gerald H. Davis, eds. and trans., Partners in the Lord's Work: The Diary of the Two Moravian Missionaries in the Creek Indian Country, 1807-1813 (Atlanta: Georgia State College, 1969), passim.

14. Hawkins to Carl Gotthold Reichel, July 8, 1807. From Moravian Archives, Winston-Salem North Carolina as quoted in Mauelshagen and Davis, eds, Partners in the Lord's Work, 7.

15. Carl Gotthold Reichel to Hawkins, April 11, 1807 as quoted in Maulelshagen and Davis, eds., Diary, 10 (Reichel is quoting Hawkins back to him).

16. Richard Thomas to Henry Gaither, Cusseta, January 28, 1798, in Letters of Hawkins, 478 (Thomas was echoing opinions frequently stated by Hawkins himself). 
17. Braund, "Guardians of Tradition and Handmaidens to Change," 239-258; Letters of Hawkins, 24.

18. Letters of Hawkins, 20-21 (meeting Sally Waters). Letters of Hawkins, 43 (meeting Sophia Durant and Mrs. Charles Weatherford), 47 (meeting "Mrs. Bailey"), 55-56 (a group of Cherokee women told him that they had determined "to accept the benevolent offers of the government."), 65 (a group of Creek women), 477 (a group of "Cusseta women").

19. Letters of Hawkins, 30-31.

20. Hawkins, Letters, 35-36.

21. Ibid.

22. Henri, Southern Indians, 127, 146-148. N.29, p. 338: Henri cites National Archives 75: 42 Correspondence of the Creek Factory, 1795-1814, Hawkins to Price, November 19, 1798 (Also in microfilmed Benjamin Hawkins letterbook, American Philosophical Society no. 215 roll 680).

23. Letters of Hawkins, 57-58.

24. In 1788, as a senator from North Carolina, Hawkins had written to the Creeks promising to come and live among them and wishing for them to find him a suitable wife from among the Creek women, one who knew Creek ways but was suitable to a senator's wife's station. Nine years later, he had reason to feel that maybe he had found that opportunity. Letters of Hawkins, 57-58. For Hawkins's earlier proposal see Hawkins to Creeks, 1788, in Caughley, McGillivray, 123.

25. Letters of Hawkins, 83.

26. Ibid., 83-85. Emphasis mine.

27. Ibid.

28. Brainerd stocked their school in an interesting way: 4.5 dozen "first books for children," 2.75 dozen "Webster's spelling book," hundreds of "school tickets," letter paper, two dozen slates and 62 slate pencils, a half-ream foolscap paper, and one "arithmetic and grammar." Then there were less obvious items simultaneously ordered that suggest a wider program of manners and labor might also have been contemplated: 2 pounds of tea, two pairs of small shoes; two small bottles of snuff; 49 pounds of nails and two handsaw files; two combs, knives, thimbles, jars, and assorted chemicals, such as zinc. The next year they bought more slate pencils, plates (for writing), a dozen "Toy books," castile soap, cheese, peppermint, magnesia, pearlash, putty, snuff, crown lancet, a barrel, a box, and other items. See: Brainerd Mission School Account Book, Volume 1, 1819-1854. Georgia Archives, p. 35 (November 15,1820 ) and p. 39 (February 22, 1821).

29. Mauelshagen and Davis, Partners in the Lord's Work, 15-16.

30. Ibid., 22-23.

31. Ibid., 49.

32. Daniel F. Littlefield, Africans and Creeks: From the Colonial Period to the Civil War (Westport, CT, 1979), 63-64. Joel W. Martin, Sacred Revolt: The Muskogees' Struggle for a New World (Boston: Beacon, 1991), 156-157

33. Cornelius to Secty. of the American Board of Missions, Choctaw Agency, December 2, 1817, Elias Cornelius Papers, 1816-1829, Duke University Special Collections; Cherokee Phoenix, April 3, 1828, April 30, 1831; Georgia Journal, January 30, 1827 all as cited in Linton McGee Collins, "The Activities of the Missionaries among the Cherokees," GHQ 6 (1922): 300-302. Green, Removal, 48-50, claims the number of schools among the Cherokee was 21. Douglas C. Wilms, "Cherokee Land Use in Georgia before Removal," in William L. Anderson, ed., Cherokee Removal: Before and After (Athens, GA, 1991), 1-28. On p. 7 a table shows there were 5 schools with 
94 students among the Cherokee in 1809 (total Cherokee population was 12,395 ) and by 1824 there were 18 schools and 314 students (total population 16,060). Wilms's number of 18 contradicts Green's 21.

34. The author, Elias Boudinot, was a Cherokee born in 1804 who received formal schooling from missionaries in New England. Boudinot was a personal embodiment of the changes in Cherokee life. He was raised with the name Gallegina until his teens. He received a formal education among missionaries in New England, converting himself in 1820 . He later became editor of the Cherokee Phoenix, which used Sequioa's Cherokee syllabary. Theda Perdue, "Introduction," Cherokee Editor: The Writings of Elias Boudinot (Knoxville, 1983), 3-38.

35. Elias Boudinot, Poor Sarah, or the Benefits of Religion Exemplified in the Life and Death of an Indian Woman n.p. [1818]. The date, place, and authorship of this extremely rare tract are unclear, but Boudinot is generally cited as the author. Perdue, Cherokee Editor, 15, 36n.32; These texts, of course, predate later events in the history of Cherokee women's literacy.

M. Amanda Moulder, "Cherokee Practice, Missionary Intentions: Literacy Learning among Early Nineteenth-Century Cherokee Women,” College Composition and Communication 63, no. 1, Indigenous and Ethnic Rhetorics (September 2011): 75-97; Phillip H. Round, Removable Type: Histories of the Book in Indian Country, 1663-1880 (Chapel Hill, NC, 2010), 148; Jace Weaver, That the People Might Live: Native American Literatures and Native American Community (Oxford, 1997), 71-72, 194.

The Female "Mite" Societies were Wadmalaw and Edisto Female Mite Society (1811), Ebenezer Female Mite Society (1816), Cheraw Hill Female Mite Society (1817), Statebury Female Mite Society (1818), Welsh Neck Juvenile Female Auxiliary Society (1819), Charleston Juvenile Female Auxiliary (1821), Charleston Female Missionary Society (1823). See: Loulie Latimer Owens, "Baptist Church Female Mite Societies," (unpublished ms.: South Caroliniana Library, 1950). Many of these groups probably did not participate in foreign missions. Others likely would have at least contributed funds as Baptist foreign missions among the Cherokee and Creeks and others began in the 1810 s.

36. Boudinot took his name from Elias Boudinot, a New Jersey politician and a president of the United States under the Articles of Confederation. He had met Boudinot, who became his patron, when he attended the American Missionary Board school in Connecticut in 1818. Galliegina, the younger Boudinot, editor of the Cherokee Phoenix, was assassinated in 1839 in retaliation for his support of the Cherokee removal. See Elias Boudinot, Poor Sarah, or the Benefits of Religion, 3.

37. Boudinot, Poor Sarah, 3.

38. Ibid., 4.

39. Ibid., 5. Did Sarah speak to Boudinot in Cherokee or in accented, ungrammatical English? If the former, why not translate for meaning rather than provide an awkward literal translation? Even if Sarah spoke in broken English, why intentionally misspell "nabor" and "misse?" In short, Boudinot's decision to represent Sarah's speech as stereotypical dialect adds to the sense that he regarded her as a pitiable object of charity.

40. Boudinot, Poor Sarah, 2-4.

41. Ibid., 4.

42. For a similar story of a young Native woman remaining behind at a mission when her family was removed westward, this time a Creek woman, see Littlefield, Africans and Creeks, 85-86. Catharine Brown, Memoir of Catharine Brown, A Christian Indian, of the Cherokee Nation, William Hoole, ed. 
(University, AL, 1986), 15-17. Draper Mss 1 YY, Doc 37, 38, and 39 indicate that Brown had a half-sister ("Mrs Looney," who had children of her own) as well as a brother named David Brown. McClinton, Moravian Springplace Mission to the Cherokees, 2: 202, 216, 217, 218, 233, 361. See also Mary A. Higginbotham. "The Creek Path Mission," Journal of Cherokee Studies (Fall 1976): 72-86.

43. Brown, Memoir, 17-18.

44. Ibid. Phillips and Phillips, Brainerd Journal, 178, 180, 183, 205.

45. Orlando Patterson, Slavery and Social Death: A Comparative Perspective (New York, 1982), passim.

46. March 17 and April 6, 1822, Jeremiah Evarts Diary, Erwin-Floyd Papers, GHS.

47. Georgia Gazette (Savannah), December 7, 1774, and Papers of Henry Laurens, 10: 206-208, 231-232 as quoted in Frey, Water from the Rock, 54 and 61-62, respectively.

48. Morgan, Slave Counterpoint, 447 (and n. 9) and 448 (and n.10), and 450 (and n.14). Morgan cites John J. Tepaske, “The Fugitive Slave: Intercolonial Rivalry and Spanish Slave Policy, 1687-1764," in Samuel Proctor, ed., Eighteenth Century Florida and Its Borderlands (Gainesville, Fla., 1975), 1-12; Jane Landers, "Spanish Sanctuary: Fugitives in Florida, 1687-1790," Florida Historical Quarterly 42 (1984): 296-313; and Landers, "Gracia Real de Santa Maria de Mose: A Free Black Town in Spanish Colonial Florida," AHR, 95 (1990), 9-30. "November 15, 1765," Journal of the Commons House of Assembly, January 17, 1763, to December 24, 1768, Inclusive, Allen D. Candler, comp., in Candler and Lamar, comps., Colonial Records of Georgia, 14: 292-293 (I am indebted to Wendy Gonaver for this reference). John Brickell, The Natural History of North Carolina (Dublin, 1737[1969 reprint]), 263. A South Carolina Colonial Assembly resolution in 1711 claimed: "There are several Negroes run away from their masters, and keep out, armed, and robbing and plundering houses and plantations, and putting the inhabitants of this Province in great fear and terror," Calumnies, 63. In an article titled "Charleston," the South Carolina Gazette reported July 10, 1736 (p. 3) that a group of Catawbas had been robbed by runaway slaves, probably maroons. And a report from February 6, 1740, in the South Carolina Journal of the Commons House of Assembly (September 12, 1739-May 10, 1740), 284286 discussed payment to Peedee-area Indians for capturing maroon slaves on the Pon Pon River. Morgan asserts that, overall, 25\% of South Carolina runaways that ran in groups were of one ethnicity. During the middle decades of the eighteenth century, however, Morgan believes that evidence is sufficient to demonstrate a decline in such ethnic-identified marronage.

49. Gonaver, "Race Relations," 11-12; Davis, The Fledgling Province.

50. Lathan A. Windley, Runaway Slave Advertisements: Georgia (Westport, CT: Greenwood Press, 1983), 23, 62.

51. Jonathan Clarke to "Dear Brother," Savannah, January 19. 1790, in Journal of Negro History 1 (1916): 77-79.

52. Morgan, Slave Counterpoint, 451.

53. "Savannah April 26," Gazette of the State of Georgia, April 26, 1787: a battle between runaways and South Carolina militia and Catawba Indians. "Savannah May 10," Gazette of the State of Georgia, May 10, 1787: attack upon a maroon camp in Patton's Swamp by South Carolina and Georgia militia and 15 Catawbas. "Savannah, May 17," Gazette of the State of Georgia, May 17, 1787: Maroon camp near Savannah was broken up and runaways were surrendering daily. Frey, Water from the Rock, 174 (estimates of freed 
people) 226-227 (ongoing slave rebellion). Frey attributes this maroon insurrectionary force's military skill to the British occupation, which is undoubtedly partly true. There is no reason to assume the absence of African military experience contributing to their organization. Georgia and South Carolina still had large proportions of African-born slaves in the 1780s. Olwell cites Joseph W. Barnwell, "The Evacuation of the British in 1782," SCHM 11 (1910): 26. After the Revolution, slave conspiracies returned to small-cell organizing, harboring difficult visions of expansion either by spontaneous recruitment or outside aid. The 1793 conspiracy rumors in port cities stretching from Savannah to Yorktown (and that might have been a hoax) involved coordination by grapevine and written correspondence. A 1797 Charleston conspiracy rested on a theory of spontaneous expansion into the countryside. In an 1813 Charleston conspiracy, the rebels expected aid from Britain, the "liberator" of 1782-1783 then at war with the United States. Robert Alderson, "Charleston's Rumored Slave Revolt of 1793," in David Geggus, ed., The Impact of the Haitian Revolution on the Atlantic World (Columbia, SC, 2001), 93-111; Frey, Water, 224-242. David Waldstreicher, In the Midst of Perpetual Fetes: The Making of American Nationalism, 1776-1820 (Chapel Hill, NC, 1997), 316-319.

54. John Johnson, Official Journal, 1791-1792, John Johnson Papers, Georgia Historical Society, Folder 1: entries for October 2, October 3, November 21, and December 20, 1791.

55. John Johnson, Official Journal, 1791-1792, John Johnson Papers, Georgia Historical Society, Folder 1: entries for December 29, December 31, January 1, January 10, January 11, February 8, February 20.

56. Sylvia Frey and Betty Wood, Come Shouting to Zion (Chapel Hill, NC, 1998), 117.

57. Furman to Dear Sir., Charleston, September 10, 1800, Richard Furman Papers, South Caroliniana Library. Richard Furman's correspondence frequently describes small groups of new converts. In 1800, for example, Furman reported that his correspondents had informed him of 20 people, "mostly Negroes," who converted at Beaufort and 5 people who joined communion in Charleston, "4 of them Negroes."

58. Welsh Neck Baptist Church Minutes, 61. A late example is from 1815 or early 1816 when Smart Williams, a slave, ran away from his master, and was excommunicated by Welsh Neck Baptist church for the act. Williams pled for restoration into the congregation that excommunicated him for seeking freedom. Although the church restored his membership in February 1816, Williams accepted admonishment and the recording of his flight as a violation of the church ordinances he had voluntarily accepted as part of his spiritual rebirth.

59. The date of 1751 is an inference on Liele's own conjecture: "I cannot justly tell what is my age . . . but I suppose I am about forty years old" See Liele to unknown, Kingston, December 18, 1791 in Journal of Negro History, v.1 (1916), 72; In Virginia, his father had already been converted and was the only slave in the area, according to Liele, whom whites and blacks believed "knew the Lord in a spiritual way." As a youth, like Gronniosaw, Liele felt "a natural fear of God ... and was often checked in conscience with thoughts of death." This fear kept Liele from "bad company," and he apparently came to believe that the good works he did as a consequence would preserve him. After his master moved him and his family to Burke County, Georgia, an evangelical minister named Matthew Moore shattered this confidence "and I was convinced that I was not in the way to heaven, but in the way to hell." 
By reading and attending sermons Liele gradually, in terms strongly reminiscent of Jonathan Edwards's Sinners in the Hands of an Angry God, came "to perceive that my life hung by a slender thread" and that God could cut it and send him to hell at any moment. About 1773, the Reverend Moore baptized Liele by full immersion. He joined the Baptist church, immediately began preaching to enslaved people, and was ordained in May 1775. Liele went to Jamaica with the British fleet after the war and founded a rapidly expanding Baptist church. Jonathan Clarke to Brother Rippon, Savannah, December 22, 1792, in ibid., 82-83.

60. Liele to unknown, Kingston, December 18, 1791, in ibid.

61. Robert G. Gardner, "Primary Sources in the Study of Eighteenth Century Georgia Baptist History," Viewpoints. Georgia Baptist History, 7 (1980), 59-118.

62. Jonathan Clarke to "Dear Brother," Savannah, January 19. 1790, in Journal of Negro History 1 (1916): 77-79.

63. Ibid.

64. Morgan, Counterpoint, 424. Bryan was born in 1737 in Goose Creek, near Charleston, the site of the Stono Rebellion, and a site where an SPG ministry had long worked among whites as well as the enslaved. He was a slave on the same plantation with both his parents, who were also slaves. It is hard to imagine that he did not know about the missionary and did not know about the Stono Rebellion, which, when he was two years old, nearly emptied his birthplace of all those white inhabitants who could afford to flee to Charleston. Although he never wrote of it, the rebellion must have had a deep impact upon his family. And the family that owned him, the family of Hugh Bryan, had been the center of a controversy in 1742 in which Hugh Bryan was rebuked by the Colonial Assembly and forced to defend himself against pointed accusations of enthusiasm and attempting to encourage slave rebellion.

65. Andrew Bryan to Reverend Brother, Savannah, December 23, 1800, Negro History 1 (January 1916): 86-87.

66. Bryan to "Reverend Brother, December 23, 1800, in Negro History 1 (January 1916): 86-87.

67. Hodgson, Remarks during a Journey though North America.

68. Mauelshagen and Davis, Partners in the Lord's Work, 39.

69. Ibid., 39, 52 .

70. Ibid., 52-53, 54.

71. Ibid., 56. Martin, Sacred Revolt, 75-77.

72. Despite recent controversy over the reality of plans for an insurrectionary uprising in Charleston in 1822, it seems irrefutable that some sort of plan was in motion and that Vesey was in some way involved, perhaps as a leader. See Douglas Egerton, He Shall go Out Free: the Lives of Denmark Vesey, Revised and Updated Edition (Oxford, 2004 [1999]), 233-252; Michael Johnson, "Denmark Vesey and His Co-Conspirators," WMQ, 3rd Ser., 58 (2001): 915-976; Robert Paquette, "From Rebellion to Revisionism: The Continuing Debate About the Denmark Vesey Affair," Journal of the Historical Society 4 (Fall 2004): 291-334; Paquette and Egerton, "Of Facts and Fables: New Light on the Denmark Vesey Affair," The South Carolina Historical Magazine 105 (2004): 8-48; and James O’Neil Spady, "Power and Confession: On the Credibility of the Earliest Reports of the Denmark Vesey Conspiracy," WMQ (2011).

73. Smallwood, Saltwater Slavery, 35-36, 217n.6 cites Foucault's Discipline and Punish. 
74. Charles C. Jones, Tenth Annual Report of the Association for the Religious Instruction of the Negroes in Liberty County, Georgia (Savannah: P.G. Thomas, 1845), 5, 6, 8-9, 10, 11-12.

75. Ibid. Other areas saw similar developments, see: Thomas S. Clay, Detail of a Plan for the Moral Improvement of Negroes on Plantations (NP, 1833), 3, 6, 7: Clay lived in Bryan County, Georgia. He argued that the long work of "philanthropists" had established a general consensus on the capacity of blacks to be morally instructed, "our inquiry, then, is limited to the best mode of communicating that instruction, and forming that character." He avoided the subjects of reading and writing and advocated oral instruction instead. He recommended a monitorial system for the adults and "Infant Schools" for mixed age groups of children, in rows not deeper than two, practicing strict cleanliness.

76. Ethan Allen Hitchcock, A Traveler in Indian Territory . . . Grant Foreman, ed. (Cedar Rapids, IA, 1930), 43.

1.Andrew Ellicott, The Journal of Andrew Ellicott . . . (Philadelphia: Budd and Bartram, 1803), 25.

2. "To the Honorable Members of the Senate, The Humble Petition of the Undersigned Citizens of the District of Williamsburg," January 18, 1811. General Assembly Petitions. South Carolina Department of Archives and History.

3. Jeremiah Evarts Diary, April 22, 1822, Erwin-Floyd Papers, GHS.

4. This is to stake a middle position corresponding to distinct but complementary positions on the yeoman attitudes and social position in the Antebellum South outlined by Lacy Ford, Origins of Southern Radicalism: The South Carolina Upcountry, 1800-1860 (New York, 1988) and Stephanie McCurry, Masters of Small Worlds: Yeoman Households, Gender Relations and the Political Culture of the Antebellum South Carolina Low Country (New York, 1995).

5. Acts of the General Assembly of the State of Georgia . . 1829 (Milledgeville: Camak \& Ragland, 1830), 168, 171, 175; Calhoun Papers 2: 141, 124-125, $171,336$.

6. Egerton, He Shall Go Out Free, 50 observes that Sandy Vesey could read and write and that Robert Vesey became a carpenter and builder, probably with Denmark's assistance or training. In 2001, Michael Johnson argued that the Denmark Vesey conspiracy was not really a slave conspiracy. It had been conjured by anxious, racist, white Charlestonians who hated Vesey and wanted the American Methodist Episcopal church closed. Johnson argued that whites jailed the accused conspirators together, where stories could be coordinated and confessions coerced. His most persistent and effective interlocutors are Douglas Egerton and Robert Pauquette. Paquette, "From Rebellion to Revisionism: The Continuing Debate About the Denmark Vesey Affair," Journal of the Historical Society 4 (Fall 2004): 291-334; Johnson's article "Denmark Vesey and His Co-Conspirators," WMQ, 3rd Ser., 58 (2001): 915-976; Paquette and Egerton, "Of Facts and Fables: New Light on the Denmark Vesey Affair," The South Carolina Historical Magazine 105 (2004): 8-48.

7. Joel Barlow to Josiah Meigs, August 28, 1805, quoted by Whitescarver on p. 455. See also Peter Onuf, Jefferson's Empire: The Language of American Nationhood (Charlottesville, VA, 2000).

8. 1783 message of Governor Lyman Hall, see Keith Whitescarver, "Creating Citizens for the Republic: Education in Georgia, 1776-1810," Journal of the Early Republic, 13 (Winter 1993): 458; "An Act for the more full and complete establishment of a seat of public learning in this State," in Watkins 
Robert and George Watkins, A Digest of the Laws of the State of Georgia . . . (Philadelphia: Aitken, 1800), 299; "An act to establish an academy in the county of Chatham," ibid., 372; The historiography of nonelite education in the region is still slim. For examples see: Rachel Klein, Unification of a Slave State: the Rise of the Planter Class in the South Carolina Backcountry, 17601808 (Chapel Hill, NC, 1990), 239-244; Linda L. Arthur, "A New Look at Schooling and Literacy: the Colony of Georgia," Georgia Historical Quarterly 84, no. 4 (Winter 2000): 563-589; Whitescarver, "Creating Citizens for the Republic: Education in Georgia, 1776-1810," 455-479; Dorothy Orr, A History of Education in Georgia (Chapel Hill, NC, 1950); Elbert Boogher, Secondary Education in Georgia, 1732-1858 (Philadelphia, 1933); Bruce Fort, "The Politics and Culture of Literacy in Georgia, 1800-1920," (Ph.D. diss., University of Virginia, 1999); Edward Cashin, The Quest: A History of Public Education in Richmond County (Columbia, SC, 1985); Edward Cashin, Beloved Bethesda: A History of George Whitefield's Home for Boys, 1740-2000 (Macon, GA, 2001). Sharon Braslaw Sundue, "Confining the Poor to Ignorance? Eighteenth Century American Experiments with Charity," History of Education Quarterly 47, no 2 (May 2007); John E. Murray, "Literacy Acquisition in an Orphanage: A Historical-Longitudinal Case Study," American Journal of Education 112 (2004): 172 and Murray, The Charleston Orphan House: Children's Lives in the First Public Orphanage in America (Chicago, 2013).

9. For examples of the continuing instability of the private venture education market: Georgia Gazette, October 30, 1788 (A Mr. Maxwell, published a cranky ad in the Georgia Gazette in 1788 complaining about nonpayment and requesting that old debts be paid "if they want he should continue teaching in Savannah"); Sheftall in the Columbian Museum and Savannah Advertiser, February 20, March 6, April 14, 1801, and June 15, 1802, and Seymour \& Woolhopter vs. Sheftall, January 30, 1807, Superior Court Proceedings of Chatham County, 1805-1808 (Benjamin Sheftall, a teacher in Savannah, struggled to survive financially, even being sued by one of his suppliers of school materials). Mrs. E.H. Steele to Miss Althethea B. Hyde, St. Mary's, Georgia, April 1, 1830, Mrs. E.H. Steele Papers, Georgia Historical Society (struggling to run a girls' school, boarding house, and academy with her husband, attempts to recruit her mother as a teacher); G. White to William Hughes, Savannah, February 24, 1819; Thomas Bacon to William Hughes, August 2, 1819; and Samuel Lewis, Sand Hills, to William Hughes, Waynesboro, August 14, 1819, Hughes-Folsom Papers, Georgia Historical Society (politics around finding and retaining teachers at a private school). Columbian Museum and Savannah Advertiser, December 10, 1802.

10. Johann David Schoepf, Travels in the Confederation [1783-1784], Alfred J. Morrison, trans. and ed. (Philadelphia, 1911), 215; Richard Boucher, A View of the Causes and Consequences of the American Revolution (London, 1797).

11. "An act for ascertaining the rights of aliens ..." in Robert and Watkins, Digest of the Laws, 303. Columbian Museum and Savannah Advertiser, December 6, 1796. George W. Waltham to William Hughes, Savannah, September 26, 1818, and Charles C. Jones Jr. to William Hughes, New York, May 23, 1876, in Hughes-Folsom Papers, 1:2, Georgia Historical Society. "Minutes and Other Records of the Mt. Zion Society, vol. 1., 1783-1795," South Caroliniana Library, January 6, 1787, 112. That such legislation did not prevent Georgians and South Carolinians from exiting the South for their education is well known. See A. Dugas to Mr. Frederick E. Dugas, 
Philadelphia, May 31, 1826, and A. Dugas to Frederick Dugas, Philadelphia, August 22, 1826, Dugas Papers, Georgia Historical Society: Dugas notes that it is almost inconceivable that a person who applied himself to his studies could not distinguish himself when they have the benefit of such a city as Philadelphia, an implicit condemnation of his home city of Augusta, Georgia.

12. Frederick A. Salzillo, "Economic and Political Foundations of Educational Reform Activity in Georgia, 1830-1840," (MA Ed., Georgia State University, 1973), 98.

13. "An Act for the more full and complete establishment of a seat of public learning in this State," in Watkins, Digest of the Laws, 299. Sally Hadden, Slave Patrols: Law and Violence and the Carolinas (Cambridge, 2001). Joyce Chaplin, An Anxious Pursuit: Agricultural Innovation and Modernity in the Lower South, 1730-1815 (Chapel Hill, NC, 1993); Michele Gillespie, Free Labor in an Unfree World: White Artisans in Slaveholding Georgia, 17891860 (Athens, GA, 2000); Timothy Lockley, Lines in the Sand: Race and Class in Lowcountry Georgia, 1750-1860 (Athens, GA, 2001), see especially Chapter Four, "Violence, Theft, and Plots," 98-130.

14. Public Funds Expended for Schools, Ledger, 1794-1840, pp. 9, 13, 17, 25, 33, 47, 55, 61, 65, 73, 97, 109, 115 (Montgomery, which also received funds in 1810), 125 (Oglethorpe Co. Academy, which received these initial funds in 1790), 141, 143 (Scriven Co. Academy, which also received funds in 1810), 175,$179 ; 1810: 11,29,49,85,87,89,93,117,133,151$. Ninety-two total counties, some with multiple academies, appear in the ledger.

15. Abraham Baldwin, "Speech to the University of Georgia Trustees," GHQ 10 (1926): 327-328, 332. Given at Savannah 1784 (possibly 1785).

16. "At a Meeting of the Saint Davids Society . . . 31 January 1778," in Horace Fraser Rudisill, ed., Minutes of the Saint David's Society, 1777-1835 (Florence, South Carolina, 1986), 2-3. Historians Margaret Nash, Jan Lewis, and Rosmarie Zagari have thoroughly revised the idea that a "republican mother" rhetoric drove education programs for women. To the extent it might have mattered, the republican motherhood concept operated only in some areas and at a time later than the first decades after the Revolution. Nash, "Rethinking Republican Motherhood: Benjamin Rush and the Young Ladies Academy of Philadelphia," Journal of the Early Republic 17 (Summer 1997): 171-191 (see esp. 189); Zagari, "Gender and the New Liberal Synthesis," American Quarterly 53 (March 2001): 123-130; See also: Kenneth Charlton, "Mothers as Educative Agents in Pre-Industrial England," History of Education 23 (1994): 129-156; Margaret Spuford, "Women Teaching Reading to Poor Children in the Seventeenth and Eighteenth Centuries," in Mary Hilton et al., eds., Opening the Nursery Door: Reading, Writing, and Childhood, 1600-1900 (Camden, 1997), 47-62.

17. Journal of the Senate of the State of South Carolina (Columbia, 1800), November 26, 1800; "Presentment of the Lexington County Grand Jury (1810)," "Presentment of the Abbeville District Grand Jury (1809)," and "Presentment of the Kershaw District Grand Jury (1804)," General Assembly Papers. South Carolina Department of Archives and History.

18. "Minutes and Other Records of the Mt. Zion Society, vol. 1., 1783-1795," 46, 53, 86-93, 104-105, 111. South Caroliniana Library, Columbia South Carolina.

19. "Minutes and Other Records of the Mt. Zion Society, vol. 1., 1783-1795," South Caroliniana Library, 86-93, 107-110.

20. These statements are an abstract of curricular information found in ads for schools and academies advertised 1787-1810 in City Gazette and Commercial 
Daily Advertiser, City Gazette and Daily Advertiser, South Carolina Gazette [Columbia], Pioneer and Yorkville Adviser, Charleston Courier, Georgetown Gazette, Columbian Museum and Savannah Daily Advertiser, and Georgia State Gazette and Independent Register. Some examples include: Columbian Museum and Savannah Advertiser, January 4, 1799, September 21, 1809 (Davis); Columbian Museum and Savannah Advertiser, January 17, 1800 ("Education"); Columbian Museum and Savannah Advertiser, November 16 and December 17, 1803 (English and Mathematical); Columbian Museum and Savannah Advertiser, February 21, 1807 and October 5, 1809 (English School); "French, Latin, English, English writing, Arithmetic, Geography, \& etc" and dancing at the "Grammer School Academy" Columbian Museum and Savannah Advertiser, January 8, 1799. Mt. Zion Society Record Book, vol. 1, p. 102, South Caroliniana Library, University of South Carolina; City Gazette and Commercial Daily Advertiser, November 19, 1787 (Carter's School); Charleston Gazette, January 1, 1797 (Columbia Academy). Mr. Johnstone's Academy (City Gazette and Daily Advertiser, January 8, 1795) offered boys and girls instruction in reading, writing, arithmetic, navigation, surveying, and "all the theoretical and practical branches of mathematics." And Mrs. O'Connor's Female Seminary offered spelling, writing English and French, grammar, arithmetic, geography, the "art of reading," and needlework (South Carolina Gazette \{Columbia\}, August 13, 1793). Edgar W. Knight, ed., A Documentary History of Education in the South before 1860, in Five Volumes, Volume IV: Private and Denominational Efforts (Chapel Hill, NC, 1953), 62-77, 81-88.

21. "Minutes and Other Records of the Mt. Zion Society, vol. 1., 1783-1795," South Caroliniana Library, January 6, 1787, 112. "Minutes of the Richmond Academy Trustees," Special Collections, Reese Library, Augusta State University. A related aside: the Georgetown Library Society in South Carolina purchased William Mavor, Historical Account of the Most Celebrated Voyages, Travels, and Discoveries, from the Time of Columbus to the Present Period (London, 1797) only four years after its publication in England. The society placed a bookplate inside with its name and the date, March 13, 1801. (My thanks to Robert MacIntosh, South Carolina Department of Archives and History, for allowing me to see and cite this edition in his personal collection.)

22. Anonymous, "Upon Virtue in General, and Female Education and Manners in Particular: Being an Inaugural Dissertation to the Opening an English Academy for young Ladies \& Misses in Savannah the 26 November 1786," (unpublished ms., Georgia Historical Society Col.13 Item no. 1), 1-2. "Certificate of Merit," December 9, 1822, Charleston, Huger Family Papers 11-484, South Carolina Historical Society. This collection also contains a certificate for "Miss Charlotte M. Huger," dated Charleston, February 11, 1818, who "has by good attention to her studies excelled those of her class in English grammar this week and thereby merits the approbation of her friends." "Mrs. Colcock's and Mrs. Ferguson's School," Accounts 1817-1819. Huger Papers, South Carolina Historical Society. Ann to Jane [Lawrence] Allen, Savannah, February 17, [1821]. Jane Lawrence Allen Papers. South Caroliniana Library.

23. Acts of the General Assembly of the State of Georgia . . 1817 (Milledgeville: State Printer, 1817), 73-74; Acts of the General Assembly of the State of Georgia . . 1822 (Milledgeville: State Printer, 1822), 4-5; Education in the United States, vol 2: 1004-1005. George H. Slappye, "Early Foundations of Georgia's System of Common School Education," GHQ 14 (June 1930): 139-149. The 1829 Charleston Directory listed 729 schools operating through South Carolina's 1811 School Act alone. John Furman Thompson, 
Foundations of the Public Schools in South Carolina (Columbia, 1925), 232. Orr, A History of Education in Georgia (Chapel Hill, 1950), 35-37.

24. In 1796, the General Assembly discussed the governor's proposal for schools under the heading of penal reform and cited Pennsylvania's recently constructed penitentiary. They took immediate action only on the reform of juries and ordered a study on schools and other issues. "Report on the Establishment of Public Schools, December 6, 1797" General Assembly Papers. South Carolina Department of Archives and History. The assembly voted not to act on December 7. For local complaints: "Presentments of the Grand Jury of Kershaw, 1804" General Assembly Papers. South Carolina Department of Archives and History; "Presentments of the Grand Jury of Abbeville, 1809" General Assembly Papers. South Carolina Archives; "Presentments of the Grand Jury of Lexington, 1810" General Assembly Papers. South Carolina Department of Archives and History; "Presentments of the Grand Jury of Laurens, 1810" General Assembly Papers. South Carolina Department of Archives and History. Robert J. Taggart, Private Philanthropy and Public Education (London, 1998), 26.

25. Journal of the Senate of the State of South Carolina (Columbia, 1800), November 26, 1800; "Presentment of the Lexington County Grand Jury (1810)," "Presentment of the Abbeville District Grand Jury (1809)," and "”Presentment of the Kershaw District Grand Jury (1804)," General Assembly Papers. South Carolina Department of Archives and History.

26. Journal of the Senate of the State of South Carolina (Columbia, 1800), November 26, 1800; "Presentment of the Lexington County Grand Jury (1810)," "Presentment of the Abbeville District Grand Jury (1809)," and "”Presentment of the Kershaw District Grand Jury (1804)," General Assembly Papers. South Carolina Department of Archives and History.

27. Francis Marion, 1795, in Edgar Wallace Knight, Public Education in the South (Boston, 1922), 115; Message of Gove. Arnoldus Vanderhhorst in City Gazette and Daily Advertiser, December 8, 1797; Message of Governor Charles Pinkney to General Assembly, City Gazette and Daily Advertiser, December 6, 1798; Governor Charles Pinckney to General Assembly, December 7, 1807, General Assembly Papers, South Carolina Department of Archives and History.

28. Henry Middleton, "Message of His Excellency the Governor, delivered to the Legislature of South Carolina, the November 26, 1811," Niles Weekly Register, December 14, 1811, 275-277.

29. Klein, Unification of a Slave State, 262-268; Mark Perry, Lift Up Thy Voice: The Grimke Family's Journey from Slaveholders to Civil Rights Leaders (Penguin, 2003), 123.

30. Federal Census, South Carolina, 1810-Williamsburg. Evidence for Williamsburg being the origination point is circumstantial but clear. All the petitions from around the state were identical, demonstrating conclusively that the Assembly was faced with a coordinated statewide effort. And all the petitions were printed, except for the one from Williamsburg, which was in manuscript form but was otherwise identical to the others in wording, spelling, and punctuation. Most likely, the Williamsburg petition was the original from which a sympathetic printer worked. If the Williamsburg petitioners had received a printed copy from somewhere else in the state, they would not have made a manuscript to circulate.

31. Rachael Klein has shown that secular and religious Backcountry elites' political and social thought was strongly hierarchical in the Early Republic. That hierarchical quality was part of the growing unity of elites built through 
marriages, the South Carolina College, and the expansion of cotton culture. See: Klein, Unification of a Slave State, 262-266, 267-268, 269-272; "To the Honorable Members of the Senate, The Humble Petition of the Undersigned Citizens of the District of Williamsburg," January 18, 1811. General Assembly Petitions. South Carolina Department of Archives and History; Knight, Education in the South, 133-138.

32. "To the Honorable Members of the Senate, The Humble Petition of the Undersigned Citizens of the District of Williamsburg," January 18, 1811. General Assembly Petitions. South Carolina Department of Archives and History; Whitescarver, 458. Flinn, "An Anniversary Address before the Charleston Orphan House" (unpublished ms., 1813), no pagination. South Caroliniana Library. Report of the Commissioners of the Lexington Free School, 1812, South Carolina Department of Archives and History.

33. Report of the Commissioners of the Free Schools of Union County, 1813, General Assembly Papers, South Carolina Department of Archives and History; Report of the Commissioners of the Free Schools of Lancaster County, 1815, General Assembly Papers, South Carolina Department of Archives and History; Reports of the Commissioners of the Free Schools of Williamsburg, 1814, 1815-1819, General Assembly Papers, South Carolina Department of Archives and History.

34. Reports of the Commissioners of the Free Schools of Union County, 1813, and Reports of the Commissioners of the Free Schools of Lancaster District, 1815, General Assembly Papers, South Carolina Department of Archives and History.

35. Thompson, Foundations of the Public Schools in South Carolina; Columbian Museum and Savannah Advertiser, January 8, 1810. Columbian Museum and Savannah Advertiser, February 14, 1800.

36. Petition of Edgefield District Residents, November 19, 1812. Petitions of the General Assembly, South Carolina Department of Archives and History. Most of the signers could not be found in the 1810 South Carolina Census, but of those who could be identified: Adam Carpenter had four boys under 10 and no slaves; Richard Johnson had one girl age 10 to 15 and no slaves; William Smith had three boys under 10, one boy under 16, one girl under 10, and 11 slaves; and Thos. Marbury had two boys and two girls under 10, one boy and one girl 10 to 15 , and 7 slaves.

Petition of Pendleton District Residents, 1816, Petitions of the General Assembly, South Carolina Department of Archives and History. Of the signers in the 1810 Census, James Dodds had one girl under 10 and no slaves; Levi Robins had three boys and one girl under 10, one boy age 10 to 15 , and one slave; Wm. Robertson had two boys and one girl under 10, one boy and one girl age 10 to 15, and six slaves; John Adams had no children and three slaves; and [John] B. Earle had three boys and two girls under 10, one boy and two girls age 10 to 15, and twenty slaves. John McKinney had a girl and a boy under 10 and no slaves.

"Minutes of the Board of Trustees for Establishing a Public School in Lancaster District and of the Trustees of Escheated Property, August 30, 1800April 15, 1840," South Carolina Department of Archives and History; Report of the Commissioners of the Lancaster Free School, 1812, South Carolina Department of Archives and History. Knight, Education in the South, 131.

37. Camden Orphan Society, Records Book, 1786-1812.

38. Camden Orphan Society, Minutes, 1822-1876: May 20, 1822 and 9 January 1823 , pp. 2, 9-10, and 13-14. 
39. John Johnson, Official Journal, 1791-1792, John Johnson Papers, Georgia Historical Society, Folder 1: entries for October 2, October 3, November 21, and December 20, 1791. Margaret Floyd to Lady Huntington, n.d., n.p. [aft June 1782] and James Habersham to Lady Huntington, Savannah, [illeg date], 1773, Chestnut College Collection (on Bethesda) MS 1130, GHS: letter describe complete loss of the house, library, and equipment in a fire in 1773 and then the plunder of its plantations by British soldiers during the Revolution.

40. The story of the demise of Bethesda: "Official Journal, 1791-1792" and "Letter book, 1791-1792" John Johnson Papers, fol.1 and fol.2, Georgia Historical Society; James Jackson Papers, 1781-1796, Georgia Historical Society; [James Jackson] to the public at large, [Feb] 1792 in Lilla M. Hawes, "Miscellaneous Papers of James Jackson, 1781-1798," GHQ 37, no. 2 (1953): 147-149 (though GHQ attributes it Jan 1792, internal evidence renders that impossible). Cashin, Beloved Bethesda, 140-151. Cashin cites: "Bethesda College (Orphan House) Trustees' Minutes, 1792-1809," typescript, Georgia Department of Archives and History.

41. In a poem mourning the fire and the seizure, John Johnson, the last proprietor of Bethesda, blasted the state from the office of a sympathetic printer in Charleston: John Johnson, The Rape of Bethesda; or The Georgia Orphan House Destroyed: A Poem (Charleston: Markland and McIver, 1792); Johnson claimed to have educated Indians and Africans at Bethesda. I am aware of no corroborating evidence for this claim, although it may have been true earlier in the era of George Whitefield. Mention of Creeks, Cherokees, and Choctaws at Bethesda: John Johnson to Sir. George, Savannah, January 13, 1792, John Johnson Collection, 430, fol.2, Georgia Historical Society. For citation of an African at Bethesda see Philip D. Morgan, Slave Counterpoint: Black Culture in the Eighteenth-Century Chesapeake and Lowcountry (Chapel Hill: University of North Carolina Press, 1998), 649-650. Acts of the General Assembly of the State of Georgia . . 1799 (Louisville: Printer to the State, 1799), 105.

42. For schools funded with public land and funds derived from public lands during the 1790s: Public Funds Expended for Schools, Ledger, 1794-1840, Georgia Archives, pp. 9, 13, 17, 25, 33, 47, 55, 61, 65, 73, 97, 109, 115, $125,141,143,175,179$. "School Bills, 1805-1826 and undated," Edward Oxford Papers. RG 048-01-001. Folder 11. Georgia Archives. Oxford's receipts reveal that he paid Thomas Gordon tuition for his own child at the Union Academy, aided funding a school building, and repeatedly paid subscription money to "the commissioners" for one or two children who likely were charity students. "Report to the Executive and Senatus Academicus for 1832 . . . Henry County Academy," Poor and Academy School Lists, Executive Department, RG 001-01-117, folder 35, Henry County Academies, Georgia Archives. "List of Pupils in Monticello Female Academy for 1837," Poor and Academy School Lists, Executive Department, RG 001-01-117, folder 40, Jasper County Academies, Georgia Archives. "Exhibit for Monticello Union Academy for the year 1832," Poor and Academy School Lists, Executive Department, RG 001-01-117, folder 40, Jasper County Academies, Georgia Archives.

43. Walter C. Hartridge Collection, Georgia Historical Society, Savannah Freeschool, box 57 fol. 961 .

44. "Rules of the Savannah Freeschool Society," February 10 and April 7, 1817, Savannah Freeschool Minutes, vol. 1, 1816-1838, Georgia Historical Society. April 6, 1818, Savannah Freeschool Minutes, vol. 1, 1816-1838, Georgia 
Historical Society. June 1 and October 5 (1818) and June 4 and September 6 (1819), Savannah Freeschool Minutes, vol. 1, 1816-1838, Georgia Historical Society.

45. November 3, 1817, Savannah Freeschool Minutes, vol. 1, 1816-1838, Georgia Historical Society.

46. Knight, Education in the South, 133-137.

47. Georgia's 1789 and 1798 constitutions each had no property requirement for voting, though both had property qualifications for office holding in the assembly and the governor. And the governors were chosen by the General Assembly, not the voters directly. Districting was radically uneven in Georgia between Upcountry and Lowcountry counties. After 1798, the proportions gradually improved the power of the Upcountry, though the inequalities were not fully equalized until constitutional revisions in the 1830s. Lucien E. Roberts, "Sectional Factors in the Movements for Legislative Reapportionment and Reduction in Georgia, 1777-1860," in James C. Bonner and Roberts, eds., Studies in Georgia History and Government (Spartanburg, SC, 1974), 94-122; Spencer B. King, Jr., Georgia Voices: A Documentary History to 1872 (Athens: University of Georgia Press, 1966), 79-81.

48. Acts of the General Assembly of the State of Georgia . . 1817 (Milledgeville: State Printer, 1817), 73-74; Journal of the Senate of the State of Georgia (Hapeville, GA: Longino and Porter, 1821), 138-140.

49. McIntosh County Academy Minutes, 1820-1875, n.p. Georgia Archives.

50. McIntosh County Academy and Free School Accounts, 1821-1827, n.p. Georgia Archives. On August 1, 1822, in compliance with new law establishing commissioners for the poor school fund, the academy paid the commissioners of the school fund \$100.00, placing the money in a bank account. That money would be enough to pay their free school teacher for four quarters.

51. Orr, A History of Education in Georgia, 76-77. Acts of the General Assembly of the State of Georgia . . 1822 (Milledgeville: State Printer, 1822), 4-5

52. In their accounts of expenditures to the governor, poor children were listed by name, sometimes under headings featuring the name of the local militia district's captain: "Report, 1830," Poor and Academy School Lists, Executive Department, RG 001-01-117, folder 5, Bibb County Poor Schools, Georgia Archives. "Poor School Report, 1829," Poor and Academy School Lists, Executive Department, RG 001-01-117, folder 50, Jones County Poor Schools, Georgia Archives. Local authorities in one district claimed to know the children were "intitled to the benefit of the poor school act." "To the Commissioners of the Poor Schools Funds," Poor and Academy School Lists, Executive Department, RG 001-01-117, folder 25, Gilmer County Poor Schools, Georgia Archives. "Montgomery County, Ga. Poor or Common School Records, 1835-1840" (Photostat, Georgia Department of Archives and History, n.d.), 2, 3, 6, 11. Richmond County, Poor Schools Book, 1854-1856, p. 67, Georgia Archives; "School Tuition of 1829," Poor School Records, 1829. Toomey Collection. RG 048-01-001. Georgia Archives.

53. It would seem that teachers probably failed competency examinations only rarely. In Franklin County, Georgia, between 1849 and 1853, of the 131 disbursements of poor school funds to pay teachers, only once did officials "suspend" a teacher's pay because he did not have a certificate of passing the exam: Franklin County Poor Schools Funds Register, 1850-1852. RG 15908-035. Georgia Archives. "Montgomery County, Ga. Poor or Common School Records, 1835-1840" (Photostat, Georgia Department of Archives and History, n.d.), 19 (qualifications of another teacher commented upon on 
p. 8). Similar commentary on qualifications to be found in Chattooga County, Georgia, in 1848. See “Ga. Chattooga County," November 21, 1848, Chattooga County Poor School Records, 1800s-1900s. RG 127-08-000. Georgia Archives. "Montgomery County, Ga. Poor or Common School Records, 1835-1840" (Photostat, Georgia Department of Archives and History, n.d.), 20, 28. "Return of the Trustees of the Poor School Fund of Bryan County for the Year 1831," Poor and Academy School Lists, Executive Department, RG 001-01-117, folder 6, Bryan County Poor/Public Schools, Georgia Archives. Wilkes County District 168 Poor School Report, 1828,” Poor School Records, 1826-1828. Toomey Collection. RG 048-01-001. Georgia Archives.

54. Virginia Steele Wood, McIntosh County Academy, McIntosh County, Georgia: Minutes of the Commissioners (1820-1875), Account Book of Students (1821-1834) (Belmont, MA: Greenwood Press, 1973), 2-3. The academy was chartered in 1794. The free schools were identified as Darien, Sand Hills (lower), Sand Hills (upper), and Harris Neck.

55. Fellowship Society Papers, Treasurer's Accounts, September 12, 1804, January 12, 1808, July 5, 1812, and March 12, 1815; Richard Hrabowski, Directory for the District of Charleston (Charleston, 1809), 105. On Denmark Vesey's literacy see: Douglas Egerton, He Shall Go out Free: The Lives of Denmark Vesey (Madison, WI, 1999), 21.

56. All of this material on the Stevens-Cogdell family was made available to me by Wendy Gonaver. I am indebted to her for all the citations and transcriptions from the Stevens/Cogdell-Sanders-/Venning Papers. Library Company of Philadelphia. BI, fol. 2. Much of this material formed part of her M.A. thesis: "Race Relations: A Family Story, 1765-1867," (MA Thesis, The College of William and Mary, 2001). Lionel Henry Kennedy, An Oration Delivered in St. Philip's Church; Before the Inhabitants of Charleston, South-Carolina. On Monday the Fifth of July, 1813 (The Fourth Being Sunday,) in Commemoration of American Independence . . . (Charleston: W.P. Young, 44 Broad-Street, 1813) as cited in Gonaver, "Race Relations," 82. An Official Report of the Trials of Sundry Negroes, Charged with an Attempt to Raise an Insurrection in the State of South-Carolina (Charleston: James R. Schenk, 1822), in the appendix, pages ii-iv: State of South-Carolina vs William Allen: Indictment for a misdemeanor, inciting slaves to insurrection.

57. John Stevens to Clement Martin, June 14, 1770. Stevens/Cogdell-Sanders-/ Venning Papers. Library Company of Philadelphia. BI, fol. 2, as cited in Gonaver, "Race Relations," 16.

58. The Directory and Stranger's Guide, for the City of Charleston; also a Directory of Charleston Neck . . . (Schenck \& Turner: at the Sign of the Ledger, No. 15, Broad Street, January 1819), 15; J. H. Easterby, A History of the College of Charleston (Charleston: College of Charleston, 1935), 262. See also, chapter three of Gonaver, "Race Relations," especially pp. 75-80.

59. John Caldwell Guilds, Simms: A Literary Life (Fayetteville, Arkansas, 1992), 12.

60. Ibid., 6-8; Sean R. Busik, A Sober Desire for History: William Gilmore Simms as Historian (Columbia, SC, 2004).

61. Guilds, Simms, 12.

62. The Directory and Stranger's Guide, for the City of Charleston; also a Directory of Charleston Neck . . . (Schenck \& Turner: at the Sign of the Ledger, No. 15, Broad Street, January 1819), 88: "Stevens, Mary, widow, 9 bedon's alley." And see The Directory and Stranger's Guide, for the City of Charleston; also a Directory of Charleston Neck ... (Published by James B. Schenck: at the Sign of the Ledger, No. 23, Broad Street; printed by Archibald E. Miller, No 4 Broad Street, 1822), "Cogdell \& Gilchrist, attornies at law, 46 Meeting; 
Cogdell, widow, Mary Ann Elizabeth, 5 St. Michael's alley; Cogdell Richard W. teller bank state S. C. 7 St. Michael's alley; and Cogdell John S. naval officer, 46 Meeting” p. 32. On page 52: "Kennedy Lionel H. attorney at law, 7 St. Michael's alley" and on page 80: "Stevens Jervis H. c. St Michael's alley r. 118 Tradd." All these addresses are either beside one another or just across an alley or street.

63. Georgia Gazette, May 27, 1767 (John Stevens teaching music in Savannah before he moved to Charleston); City Gazette and Daily Advertiser, January 1, 1795 ("Mrs. Cogdell" teaching needlework and etc. in Charleston). See also, chapter one of Gonaver, "Race Relations,"

64. Carl Kaestle, Pillars of the Republic: Common Schools and American Society, 1780-1860 (New York, 1983), 203-204.

65. Acts of the General Assembly of the State of Georgia . . 1829 (Milledgeville: Camak \& Ragland, 1830), 168, 171, 175.

66. The estimate for slaves is from Cremin. The percentages from Georgia and South Carolina are rounded-up calculations from the 1850 Census returns, which asked respondents to volunteer whether they were able to read and write. See J. D. B. DeBow, The Seventh Census of the United States: 1850 (Washington: Robert Armstrong, 1853), ix, lxi. See also: James C. Bonner, et al, A History of Public Education in Georgia, 1734-1976 (Columbia, SC, 1979), 32; Ronald J. Zboray, A Fictive People: Antebellum Economic Development and the American Reading Public (New York, 1993), 196-197, 198, 200.

67. Calhoun Papers, 2: 141, 124-125, 171, 336. Michael D. Green, The Politics of Indian Removal: Creek Government and Society in Crisis (Lincoln, NE, 1982), 48-50; Bernard Sheehan, Seeds of Extinction: Jeffersonian Philanthropy and the American Indian (Chapel Hill, NC, 1973), 119-120, 137, 143, 248-249, 262, 266. See also: R. Pierce Beaver, Church, State, and the American Indians (St. Louis, 1966) and Robert Berkofer, Salvation and the Savage, 1787-1862 (Lexington, 1965). Douglas C. Wilms, "Cherokee Land Use in Georgia before Removal," in William L. Anderson, ed., Cherokee Removal: Before and After (Athens, GA, 1991), 1-28. On p. 7 a table shows that there were 5 schools with 94 students among the Cherokee in 1809 (total Cherokee population was 12,395) and there were 18 schools and 314 students (total population 16,060 ) by 1824 . Wilms's number of 18 contradicts Green's 21.

1.Edward E. Baptist and Stephanie M. H. Camp, New Studies in the History of American Slavery (Athens, GA, 2006), 1-18; Edward E. Baptist, The Half Has Never Been Told: Slavery and the Making of American Capitalism (New York, 2014); Stephanie Smallwood, Saltwater Slavery: A Middle Passage from Africa to American Diaspora (New York, 2007); Woody Holton, Forced Founders: Indians, Debtors, Slaves, of the Making of the American Revolution in Virginia (Chapel Hill, NC, 1999), 164-188; Philip D. Morgan, Slave Counterpoint: Black Culture in the Eighteenth-Century Chesapeake and Lowcountry (Chapel Hill, NC, 1998); Sylvia Frey, Water from the Rock: Black Resistance in a Revolutionary Age (Princeton, 1991); Joyce Chaplin, An Anxious Pursuit: Agricultural Innovation and Modernity in the Lower South, 1730-1815 (Chapel Hill, NC: University of North Carolina Press, 1993); Jack P. Greene, Pursuits of Happiness: The Social Development of Early Modern British Colonies and the Formation of American Culture (Chapel Hill, NC, 1988); Edmund S. Morgan, American Slavery, American Freedom: The Ordeal of Virginia (New York, 1975); Vine Deloria Jr., Custer Died for Your Sins: An Indian Manifesto (New York, 1969); Francis 
Jennings, The Invasion of America: Indians, Colonialism, and the Cant of Conquest (New York, 1975).

2. Greene, Pursuits of Happiness; Sharon Braslaw Sundue, Industrious in their Stations: Young People at Work in Early America (Charlottesville, VA, 2009), 57-90; Carl Kaestle, Pillars of the Republic: Common Schools and American Society, 1780-1860 (New York, 1983), 3-4. E. Jennifer Monaghan, Learning to Read and Write in Colonial America: Literacy Instruction and Acquisition in Cultural Context (Amherst, MA, 2005). See Thomas Woody, History of Women's Education in the United States, 2 vols (New York, 1929), 1: 301302, 229-233 as cited by Nash, "Rethinking," 173 (n. 6). My thinking on "exclusion" here follows Giorgio Agamben, State of Exception, Kevin Atell, trans. (Chicago, 2005), passim.

3. Giorgio Agamben, State of Exception, 40 (quote). And see also an excellent discussion of Agamben and slavery in Magnus Fiskesjö, "Outlaws, Barbarians, Slaves: Critical Reflections on Agamben's homo sacer," Hau: Journal of Ethnographic Theory 2 (2012): 161-180.

4. See for example the debate between Michael Zuckerman, Aaron S. Fogleman, Kathleen M. Brown, John M. Murrin, and Robert A. Gross, "Deference or Defiance in Eighteenth-Century America? A Round Table," JAH 85, no. 1 (June 1998): 13-110.

5. City Gazette or Daily Advertiser, February 8, 1788 (quote). An excellent study of education in South Carolina during the Antebellum period confirms the trajectory of race and education that I have described in this book: Bruce W. Eelman, “ 'An Educated and Intelligent People Cannot be Enslaved': The Struggle for Common Schools in Antebellum Spartanburg, South Carolina," History of Education Quarterly 44, no. 2 (Summer 2004): 250-271. The article's first lines: “As the political conflict over slavery's fate in the West intensified through the summer of 1849 , Peter M. Wallace, editor of the Spartanburg Carolina Spartan, vowed that he was 'utterly opposed now and forever to all political compromises' on the issue of slavery. Significantly, Wallace connected the success of Southern resistance to the improvement of South Carolina's free schools" (p. 250).

6. Ronald J. Zboray, A Fictive People: Antebellum Economic Development and the American Reading Public (New York, 1993), 196-197, 198, 200.

7. Kaestle, Pillars of the Republic, 30-61; Carl F. Kaestle, The Evolution of an Urban School System: New York City, 1750-1850 (Cambridge: Harvard University Press, 1973).

8. Peter A. Coclanis, The Shadow of a Dream: Economic Life and Death in the South Carolina Low Country, 1670-1920 (New York, 1989); Chaplin, An Anxious Pursuit; Barbara Bellows, Benevolence Among Slaveholders: Assisting the Poor in Charleston, 1670-1860 (Baton Rouge, 1993).

9. Bernard Bailyn, Education in the Formation of American Society (Chapel Hill, NC, 1970), 113 (quotations). J. Franklin Jameson, The American Revolution Considered as a Social Movement (Princeton, NJ, 1973 [1926]); Alfred F. Young, "American Historians Confront 'The Transforming Hand of Revolution," in Ronald Hoffman and Peter J. Albert, eds., The Transforming Hand of Revolution: Reconsidering the American Revolution as a Social Movement. (Charlottesville, VA, 1996).

10. Kaestle, Pillars of the Republic, 6, 191, 218-219.

11. John Wood Sweet, Bodies Politic: Negotiating Race in the American North, 1730-1830 (Baltimore, 2003), 406-407.

Anderson, Virginia DeJohn. Creatures of Empire: How Domestic Animals Transformed Early America. Oxford and New York: Oxford University Press, 2004. 
Anonymous, A Letter from the Revd. Mr. Sergeant of Stockbridge, to Dr. Colman of Boston . . Containing Mr. Sergeant's Proposal of a More Effectual Method for the Education of Indian Children; to Raise 'em if Possible into a Civil and Industrious People; by Introducing the English Language Among Them; and Thereby Instilling into Their Minds and Hearts, with a More Lasting Impression, the Principles of Virtue and Piety. Boston: Rogers and Fowle, 1743.

Armitage, David. The Ideological Origins of the British Empire. Cambridge: Cambridge University Press, 2000.

Baine, Rodney M. "James Oglethorpe and the Early Promotional Literature for Georgie." William and Mary Quarterly, 3rd Ser., 45, no. 1 (1988).

_. "New Perspectives on Debtors in Colonial Georgia." Georgia Historical Quarterly 77 (1993): 1-19.

—. "Oglethorpe's Forty Irish 'Convicts.'” Georgia Historical Quarterly 77 (1994): 326-338.

- The Publications of James Edward Oglethorpe. Athens, GA: The University of Georgia Press, 1994.

Banner, Lois W. "Religious Benevolence as Social Control: A Critique of an Interpretation." Journal of American History 60 (1973): 23-41.

Baylin, Bernard. The Ideological Origins of the American Revolution. Cambridge, MA: Harvard University Press, 1992.

Beckert, Sven. The Empire of Cotton: A Global History. New York: Alfred A. Knopf, 2014.

Braund, Kathryn E. Holland. Deerskins and Duffels: The Creek Indian Trade with Anglo America, 1685-1815. Lincoln, NE: University of Nebraska Press, 1993.

Brickell, John. The Natural History of North Carolina. Dublin, 1737 [1969 reprint].

Brooks, Joanna, and John Saillant, eds. Face Zion Forward: First Writers of the Black Atlantic, 1785-1798. Lebanon, NH: University Press of New England, 2002.

Brown, William Garrott. The Lower South in American History. New York and London: The Macmillan Company, 1902.

Cain, P. J., and A. G. Hopkins. British Imperialism: 1688-2000. 2nd Edition. London: Longman Publishing, 2002.

Caldwell, Lee Ann. "New Deal on a New Frontier: European Women Colonists and Trustee Policy, 1733-1752." Journal of the Georgia Association of Historians 16 (1995): 106-126.

Candler, Allen D. The Colonial Records of the State of Georgia. New York: AMS Press, 1970 [1904-1916].

Carney, Judith A. Black Rice: The African Origins of Rice Cultivation in the Americas. Cambridge: Harvard University Press, 2001.

Cates, Gerald L. " 'The Seasoning': Disease and Death among the First Colonists of Georgia.” Georgia Historical Quarterly 64, no. 2 (1980): 146-158.

Chaplin, Joyce. An Anxious Pursuit: Agricultural Innovation and Modernity in the Lower South, 1730-1815. Chapel Hill, NC: Institute of Early American History and Culture, 1993.

Davis, Andrew McFarland. Colonial Currency Reprints, 1682-1751. Boston: Prince Society, 1911. 
Davis, Harold E. The Fledgeling Province: Social and Cultural Life in Colonial Georgia, 1733-1776. Chapel Hill, NC: University of North Carolina Press, 1976.

Dickson, Peter. The Financial Revolution in England; A Study of the Development of Public Credit. London: Macmillan, 1967.

Dowd, Gregory Evans. A Spirited Resistance: The North American Indian Struggle for Unity, 1745-1815. Baltimore: Johns Hopkins University Press, 1993.

- War under Heaven: Pontiac, the Indian Nations, and the British Empire. Baltimore: Johns Hopkins University Press, 2004.

Dunn, Richard. "The Trustees of Georgia and the House of Commons, 17321752." William and Mary Quarterly, 3rd Ser., 11 (1954).

Edgar, Walter B. South Carolina: A History. Columbia, SC: University of South Carolina Press, 1998.

Eltis, David. The Rise of African Slavery in the Americas. Cambridge: Cambridge University Press, 2000.

Ethridge, Robbie. Creek Country: The Creek Indians and Their World. Chapel Hill, NC: University of North Carolina Press, 2003.

Ethridge, Robbie, and Sheri M. Shuk-Hall, eds. Mapping the Mississippian Shatter Zone: The Colonial Indian Slave Trade and Regional Instability in the American South. Lincoln: University of Nebraska Press, 2009, 188-249.

Fields-Black, Edda L. Deep Roots:' Rice Farmers in West Africa and the African Diaspora. Bloomington: University of Indiana Press, 2008.

Foucault, Michel. Madness and Civilization: A History of Insanity in the Age of Reason. Richard Howard, trans. New York, 1965.

- Discipline and Punish: The Birth of the Prison, Alan Sheridan, trans. New York: Random House, 1977.

- The History of Sexuality: Volume 1, an Introduction. Robert Hurley, trans. New York: Pantheon Books, 1978.

Frey, Sylvia. Water from the Rock: Black Resistance in a Revolutionary Age. Princeton, NJ: Princeton University Press, 1991.

Gallay, Alan. The Indian Slave Trade: The Rise of the English Empire in the American South, 1670-1717. New Haven: Yale University Press, 2002.

Gates, Henry Louis Jr. "James Gronniosaw and the Trope of the Talking Book." In William L. Andrews, ed. African American Autobiography: A Collection of Critical Essays. Englewood Cliffs, NJ: Prentice Hall, 1993.

Gonaver, Wendy. "Race Relations: A Family Story, 1765-1867.” MA Thesis, College of William and Mary, 2001.

Greene, Jack P. Selling a New World: Two Colonial South Carolina Promotional Pamphlets by Thomas Nairne and John Norris. Columbia, SC: University of South Carolina Press, 1989.

Greer, Allan. "Commons and Enclosure in the Colonization of North America." The American Historical Review 117, no. 2 (April 1, 2012): 365-386.

Hahn, Steven C. The Invention of the Creek Nation, 1670-1763. Lincoln, NE: University of Nebraska Press, 2004.

Hall, David. Cultures of Print: Essays in the History of the Book. Amherst, MA: University of Massachusetts Press, 1996.

Hatley, Tom. The Dividing Paths: Cherokees and South Carolinians Through the Era of Revolution. Oxford: Oxford University Press, 1995. 
Hitchcock, Tim. English Sexualities, 1700-1800. Basingstoke: Palgrave Macmillan, 1997.

Hudson, Charles M. The Southeastern Indians. Knoxville, TN: University of Tennessee Press, 1978.

Hudson, Charles M., and Carmen Chaves Tesser, eds. The Forgotten Centuries: Indians and Europeans in the American South, 1521-1704. Athens, GA: University of Georgia Press, 1994.

Jackson, Harvey H., and Phinzy Spalding, eds. Forty Years of Diversity: Essays on Colonial Georgia. Athens, GA: University of Georgia Press, 1984.

John K. Thornton. "African Dimensions of the Stono Rebellion." The American Historical Review 96, no. 4 (1991): 1101-1113.

Jones, David S. "Virgin Soils Revisited." William and Mary Quarterly 60, no. 4 (October 1, 2003): 703.

Landers, Jane. "Spanish Sanctuary: Fugitives in Florida, 1687-1790." Florida Historical Quarterly 42 (1984): 296-313.

_. "Gracia Real de Santa Maria de Mose: A Free Black Town in Spanish Colonial Florida.” American Historical Review 95 (1990): 9-30.

Laqueur, Thomas Walter. Religion and Respectability: Sunday Schools and Working Class Culture, 1780-1850. New Haven, CT: Yale University Press, 1976.

Lawson, John. A New Voyage to Carolina. Ann Arbor: University Microfilms, 1966 [1709].

Linebaugh, Peter, and Marcus Rediker. The Many-Headed Hydra: Sailors, Slaves, Commoners, and the Hidden History of the Revolutionary Atlantic. Boston: Beacon Press, 2000.

Littlefield, Daniel C. Rice and Slaves: Ethnicity and the Slave Trade in Colonial South Carolina. Urbana: University of Illinois Press, 1981.

Locke, John. Locke: Political Essays. Mark Goldie, ed. Cambridge: Cambridge University Press, 1997.

Lugones, Maria. "Heterosexualism and the Colonial/Modern Gender System." Hypatia 22, no. 1 (2007): 186-209.

Mackay, Charles. Extraordinary Popular Delusions and the Madness of Crowds. Cambridge, MA: Farrar Straus and Giroux, 1972 [1841].

Malcomson, Scott L. One Drop of Blood: American Misadventure of Race. New York: Farrar, Straus and Giroux, 2001.

Mancall, Peter, Joshua Rosenbloom, and Thomas Weiss. "Conjectural Estimates of Economic Growth in the Lower South: 1720-1800." In William A. Sundstrom, et al., eds. History Matters: Essays on Economic Growth, Technology, and Demographic Change. Stanford, CA: Stanford University Press, 2003.

Martyn, Benjamin. Reasons for Establishing the Colony of Georgia . . . London, 1733.

Monaghan, E. Jennifer. Learning to Read and Write in Colonial America. Amherst: University of Massachusetts Press, 2005.

Morgan, Edmund S. American Slavery, American Freedom: The Ordeal of Virginia. New York: Norton, 1975.

Morgan, Philip D. Slave Counterpoint: Black Culture in the Eighteenth-Century Chesapeake and Lowcountry. Chapel Hill, NC: University of North Carolina Press, 1998. 
Morris, Michael P. The Bringing of Wonder: Trade and the Indians of the Southeast, 1700-1783. Westport, CT: Praeger Publishers, 1999.

Oglethorpe, James. "Account of the Provinces of South Carolina and Georgia (1732)." In Rodney M. Baine, ed. The Publications of James Edward Oglethorpe. Athens: University of Georgia Press, 1994.

Owen, David. English Philanthropy: 1660-1960. Cambridge, MA: Belknap Press, 1964.

Paulett, Robert E. An Empire of Small Places: Mapping the Southeastern AngloIndian Trade, 1732-1795. Athens, GA: University of Georgia Press, 2012.

Perdue, Theda. Cherokee Women: Gender and Culture Change, 1700-1835. Lincoln: University of Nebraska Press, 1998.

Piker, Joshua. Okfuskee: A Creek Indian Town in Colonial America. Cambridge, MA: Harvard University Press, 2006.

Quijano, Anibal. "The Coloniality of Power, Eurocentrism, and Latin America." Nepentla 1 (2000): 533-580.

Richter, Daniel K. Facing East from Indian Country: A Native History of Early America. Cambridge, MA: Harvard University Press, 2002.

Salisbury, Neal. "The Indians' Old World: Native Americans and the Coming of Europeans." The William and Mary Quarterly 53, no. 3 (1996): 435-458.

Saunders, Rebecca. Stability and Change in Guale Indian Pottery, A.D. 13001702. Tuscaloosa: The University of Alabama Press, 2000.

Saunt, Claudio. A New Order of Things: Property, Power, and the Transformation of the Creek Indian, 1733-1816. New York: Cambridge University Press, 1999.

Shoemaker, Nancy. A Strange Likeness: Becoming Red and White in EighteenthCentury North America. New York: Oxford University Press, 2004.

Silver, Timothy. A New Face of the Countryside. New York: Cambridge University Press, 1990.

Silverman, David J. Thundersticks: Firearms and the Violent Transformation of Native America. Cambridge, MA: The Belknap Press of Harvard University Press, 2016 [1971].

Smallwood, Stephanie E. Saltwater Slavery: A Middle Passage from Africa to American Diaspora. Cambridge, MA: Harvard University Press, 2007.

Smith, Marvin T. 2000. Coosa: The Rise and Fall of a Southeastern Mississippian Chiefdom. Gainesville, FL: University Press of Florida.

Snell, William Robert. "Indian Slavery in Colonial South Carolina, 1671-1795." Ph.D. diss., University of Alabama, 1972.

Spady, James O'Neil. "Chapter Eight: Bubbles and Beggars and the Bodies of Laborers: The Georgia Trusteeship's Colonialism Reconsidered.” In Constructing Early Modern Empires: Proprietary Ventures in the Atlantic World, 15001750. Leiden, The Netherlands: Brill, 2007.

Stern, Jessica. The Lives of Objects: Native Americans, British Colonists, and Cultures of Labor and Exchange in the Southeast. Chapel Hill, NC: University of North Carolina Press, 2016.

Sweet, Julie Anne. Negotiating for Georgia: British-Creek Relations in the Trustee Era, 1733-1752. Athens, GA: University of Georgia Press, 2004.

TePaske, John J. "The Fugitive Slave: Intercolonial Rivalry and Spanish Slave Policy, 1687-1764." In Samuel Proctor, ed. Eighteenth Century Florida and Its Borderlands Gainesville, FL: University Press of Florida, 1975. 
Thornton, John K. Africa and Africans in the Making of the Atlantic World, 1400-1800. Cambridge: Cambridge University Press, 2nd expanded ed., 1998.

Thorpe, Francis Newton. The Federal and State Constitutions Colonial Charters, and Other Organic Laws of the States, Territories, and Colonies Now or Heretofore Forming the United States of America. Washington, DC: Government Printing Office, 1909.

Toland, John. A Collection of Several Pieces of Mr. Toland . . London: Printed for J. Peele, 1726.

Trenchard, John and Thomas Gordon. Cato's Letters: Essays on Liberty, Civil and Religious, and Other Important Subjects. New York: Russell \& Russell, [1969].

Urban, Greg, and Jackson Baird, Jackson. "Social Organization." In William Sturtevant and Raymond D. Fogelson, eds. Handbook of the North American Indians. Vol. 14. Washington, DC: Smithsonian Institution, 2004.

Usner, Daniel H. Indians, Settlers \& Slaves in a Frontier Exchange Economy: The Lower Mississippi Valley before 1783. Chapel Hill, NC: University of North Carolina Press, 1992.

Wheelock, Eliazur. A Brief Narrative of the Indian Charity-School in Lebanon in Connecticut, New England . . London: J. and W. Oliver, 1767 [Boston, 1763].

Wickman, Patricia Riles. The Tree That Bends: Discourse, Power, and the Survival of the Maskókî People. Tuscaloosa: University of Alabama Press, 1999.

William A. Sundstrom, and Warren Whatley, eds. History Matters: Essays on Economic Growth, Technology, and Demographic Change. Stanford, CA: Stanford University Press, 2004, 1-19.

Windley, Lathan A. Runaway Slave Advertisements: Georgia. Westport, CT: Greenwood Press, 1983.

Wood, Betty. Slavery in Colonial Georgia, 1730-1775. Athens, GA: University of Georgia Press, 1984.

Wood, Peter. Black Majority: Negroes in Colonial South Carolina from 1670 Through the Stono Rebellion. New York: Norton, 1974.

- Powhatan's Mantel: Indians in the Colonial Southeast. Lincoln, NE: University of Nebraska Press, 1989.

Adair, James, and Samuel Cole Williams. Adair's History of the American Indians. New York: Published for University Microfilms, Ann Arbor by Argonaut Press, 1966.

Anonymous, A New Voyage to Georgia, by a Young Gentleman, Giving an Account of His Travels to South Carolina, and Part of North Carolina, to Which Is Added, a Curious Account of the Indians by an Honourable Person, and a poem to James Oglethorpe. London: Printed for J. Wilford, 1737.

- A Letter from the Revd. Mr. Sergeant of Stockbridge, to Dr. Colman of Boston ... Containing Mr. Sergeant's Proposal of a More Effectual Method for the Education of Indian Children; to Raise 'em if Possible into a Civil and Industrious People; by Introducing the English Language Among Them; and Thereby Instilling into Their Minds and Hearts, with a More Lasting Impression, the Principles of Virtue and Piety. Boston: Rogers and Fowle, 1743.

Atkin, Edmond. Indians of the Southern Frontier: The Edmond Atkin Report and Plan of 1755. Wilbur R. Jacobs, ed. Columbia, SC: University of South Carolina Press, 1954. 
Axtell, James. After Columbus: Essays in the Ethnohistory of Colonial North America. Oxford: Oxford University Press, 1988.

Bartram, William. Travels Through North \& South Carolina, Georgia, East \& West Florida the Cherokee Country, the Extensive Territories of the Muscogulges, or Creek Confederacy, and the Country of the Chactaws. PA: James \& Johnson 1791. Francis Harper. Ed. New Haven, CT: Yale University Press, 1958. Reprint, Athens, GA: University of Georgia Press, 1998.

Bhabha, Homi K. The Location of Culture. New York: Routledge, 1994.

Bly, Antonio. "Reed through the Bybell: Slave Literacy in Early Virginia." Book History 16 (2013): 1-33.

Bosomworth, Thomas. "Journal of Thomas Bosomwoth.” In William L. McDowell, ed. Documents Relating to Indian Affairs. Columbia, SC: South Carolina Department of Archives and History, 1970, 268-294.

Brickell, John. The Natural History of North Carolina. Dublin, 1737 [1969 reprint].

Caldwell, Joseph, and Catherine McCann. Irene Mound Site: Chatham County Georgia. Savannah, GA: WPA Archaeological Project, 1941.

Candler, Allen D. The Colonial Records of the State of Georgia. New York: AMS Press, 1970 [1904-1916].

Carreta, Vincent. Equiano, the African: Biography of a Self-Made Man. New York: Penguin, 2007.

Chekilli Paper, 1735. Georgia Historical Society.

Collections of the Georgia Historical Society, Vol. VI, The Letters of the Hon: James Habersham, 1756-1775. Savannah, GA: The Georgia Historical Society, 1904.

Cooper, Thomas, and David McCord, eds. The Statutes at Large of South Carolina: Edited under Authority of the Legislature. Columbia, SC: University of South Carolina Press, 1837.

Corry, John P. "Some New Light on the Bosomsworth Claims." The Georgia Historical Quarterly 25, no. 3 (September 1941): 195-224.

Coulter, Merton E. Georgia: A Short History. Chapel Hill, NC: University of North Carolina Press, 1960 [1933].

Crane, Verner W. "A Lost Utopia on the First American Frontier." Sewanee Review 27 (January 1919): 48-61.

Davis, Harold E. The Fledgeling Province: Social and Cultural Life in Colonial Georgia, 1733-1776. Chapel Hill, NC: University of North Carolina Press, 1976.

Dowd, Gregory Evans. A Spirited Resistance: The North American Indian Struggle for Unity, 1745-1815. Baltimore: Johns Hopkins University Press, 1993.

Egmont, John Percival. The Journal of the Earl of Egmont: Abstracts of the Trustees Proceedings for Establishing the Colony of Georgia, 1732-1738, Robert G. McPherson, ed. Athens, GA: University of Georgia Press, 1962.

Fick, Carolyn E. Making Haiti: Saint Domingue Revolution From Below. Knoxville: University of Tennessee Press, 1990.

Fisher, Doris B. "Mary Musgrove: Creek Englishwoman.” Ph.D. diss., Emory University, 1990.

Foster, Gertrude, comp. "A Documentary History of Education in South Carolina as Revealed in the Manuscripts of the Society for the Propagation of the Gospel in Foreign Parts.” Ed.D., University of South Carolina, 1932. 
Frey, Sylvia. Water from the Rock: Black Resistance in a Revolutionary Age. Princeton, NJ: Princeton University Press, 1991.

Gallay, Alan. The Indian Slave Trade: The Rise of the English Empire in the American South, 1670-1717. New Haven: Yale University Press, 2002.

Gates, Henry Louis Jr. "James Gronniosaw and the Trope of the Talking Book." In William L. Andrews, ed. African American Autobiography: A Collection of Critical Essays. Englewood Cliffs, NJ: Prentice Hall, 1993.

Geggus, David Patrick. Haitian Revolutionary Studies. Bloomington: Indiana University Press, 2002.

Genovese, Eugene. From Rebellion to Revolution: Afro-American Slave Revolts in the Making of the Modern World. Baton Rouge: Louisiana State University Press, 1979.

Georgia Gazette [Savannah].

Gonaver, Wendy. "Race Relations: A Family Story, 1765-1867.” MA Thesis, College of William and Mary, 2001.

Grant, Ludovick. "Historical Relation of Facts ..." South Carolina Magazine of Genealogy and History 10 (1909): 59.

Greene, Jack P. “'A Plain and Natural Right to Life and Liberty': An Early Natural Rights Attack on the Excesses of the Slave System in Colonial British America." The William and Mary Quarterly 57, no. 4 (2000): 793-808.

Gundaker, Grey. Signs of Diaspora, Diaspora of Signs: Literacies, Creolization, and Vernacular Practice in African America. New York: Oxford University Press, 1998.

Hahn, Steven C. The Life and Times of Mary Musgrove. Gainesville, FL: University Press of Florida, 2012.

Hatley, Tom. The Dividing Paths: Cherokees and South Carolinians Through the Era of Revolution. Oxford: Oxford University Press, 1995.

Henry Ellis Papers. Savannah, GA: Georgia Historical Society.

Hertzler, James R. "Slavery in the Yearly Sermons before the Georgia Trustees." Georgia Historical Quarterly 59 (Supplement 1975): 118-126.

Higginbotham, Leon A. In the Matter of Color: Race and the American Legal Process: The Colonial Period. New York: Oxford University Press, 1978.

Jackson, Harvey H., and Phinzy Spalding, eds. Forty Years of Diversity: Essays on Colonial Georgia. Athens, GA: University of Georgia Press, 1984.

Jesse Franklin Indian Treaty Papers. The Southern Historical Collection. Louis Round Wilson Special Collections Library. Chapel Hill, NC: University of North Carolina Press, 1816.

John K. Thornton. "African Dimensions of the Stono Rebellion.” The American Historical Review 96, no. 4 (1991): 1101-1113.

Landers, Jane. "Spanish Sanctuary: Fugitives in Florida, 1687-1790." Florida Historical Quarterly 42 (1984): 296-313.

_. "Gracia Real de Santa Maria de Mose: A Free Black Town in Spanish Colonial Florida." American Historical Review 95 (1990): 9-30.

Laurens, Henry, Philip M. Hamer, George C. Rogers, and David R. Chesnutt. The Papers of Henry Laurens. Columbia, SC: Published for the South Carolina Historical Society by the University of South Carolina Press, 1968-2003.

Le Jau, F., and F. J. Klingberg (Frank Joseph). The Carolina Chronicle of Dr. Francis Le Jau, 1706-1717. Berkeley: University of California Press, 1956. 
Littlefield, Daniel F. Africans and Creeks: From the Colonial Period to the Civil War. Westport, CT: Greenwood Press, 1979.

Martin, Joel W. Sacred Revolt: The Muskogees' Struggle for a New World. New York: Beacon Press, 1991.

Mellon, William Knox Jr. “Christian Prieber's Cherokee 'Kingdom of Paradise.' ” Georgia Historical Quarterly 57 (1973): 319-331.

Merrell, James. The Indians' New World: Catawbas and Their Neighbors from European Contact through the Era of Removal. Chapel Hill, NC: University of North Carolina Press, 1989.

Morgan, Philip D. Slave Counterpoint: Black Culture in the Eighteenth-Century Chesapeake and Lowcountry. Chapel Hill, NC: University of North Carolina Press, 1998.

Nelson, Megan Kate. Trembling Earth: A Cultural History of the Okefenokee Swamp. Athens: University of Georgia Press, 2005.

O'Connell, Neil J. "George Whitefield and Bethesda Orphan-House.” The Georgia Historical Quarterly 55 (1970): 41-62.

Paulett, Robert E. An Empire of Small Places: Mapping the Southeastern AngloIndian Trade, 1732-1795. Athens, GA: University of Georgia Press, 2012.

Perdue, Theda. Cherokee Women: Gender and Culture Change, 1700-1835. Lincoln: University of Nebraska Press, 1998.

Piker, Joshua. The Four Deaths of Acorn Whistler: Telling Stories in Colonial America. Cambridge, MA: Harvard University Press, 2013.

Potkay, Adam, and Sandra Burr, eds. Black Atlantic Writers of the Eighteenth Century: Living the New Exodus in England and the Americas. New York: Palgrave Macmillan, 1995.

Potter, Elam. "An Account of Several Nations of Southern Indians: In a Letter from Reverend Elam Potter to Reverend Dr. Stiles, A.D. 1768." Massachusetts Historical Society Proceedings, 1st Ser., 10 (1809).

Proctor, Samuel. Eighteenth Century Florida and Its Borderlands. Gainesville, FL: University Press of Florida, 1975.

Ready, Milton. "The Georgia Trustees and the Malcontents: The Politics of Philanthropy." Georgia Historical Quarterly 60, no. 3 (1976): 264-281.

Reese, Trevor R., ed. The Clamorous Malcontents: Criticisms and Defenses of the Colony of Georgia, 1741-1743. Savannah, GA: Beehive Press, 1973.

Richter, Daniel K. Facing East from Indian Country: A Native History of Early America. Cambridge, MA: Harvard University Press, 2002.

Rogers, George C. Charleston in the Age of the Pinckneys. Columbia, SC: University of South Carolina Press, 1980.

Rules and Regulations of the Brown Fellowship Society, 1790. Charleston, SC: J. B. Nixon, 1844.

San Juan, E. Beyond Postcolonial Theory. New York: St. Martin's Press, 1999.

- A New Order of Things: Property, Power, and the Transformation of the Creek Indian, 1733-1816. New York: Cambridge University Press, 1999.

Saunt, Claudio. “'Domestick . . . Quiet being broke': Gender Conflict among Creek Indians in the Eighteenth Century.” In F. J. Teute and R. L. Cayton, eds. Contact Points. Chapel Hill, NC: University of North Carolina Press, 1998.

- "The English Has Now a Mind to Make Slaves of Them All: Creeks, Seminoles, and the Problem of Slavery." American Indian Quarterly 22 (1998): 157-181. 
. "Taking Account of Property: Social Stratification Among the Creek Indians in the Early Nineteenth Century." The William and Mary Quarterly 24 (2000): 733-760.

Schwarze, Edmund. History of the Moravian Missions Among Southern Indian Tribes of the United States. Bethlehem, PA: Times Publishing Co., 1923.

Smallwood, Stephanie. Saltwater Slavery: A Middle Passage from Africa to American Diaspora. Cambridge: Harvard University Press, 2007.

South Carolina Gazette.

Sweet, Julie Anne. Negotiating for Georgia: British-Creek Relations in the Trustee Era, 1733-1752. Athens, GA: University of Georgia Press, 2004.

Szasz, Margaret Connell. Indian Education in the American Colonies, 16071783. Albuquerque: University of New Mexico Press, 1988.

TePaske, John J. "The Fugitive Slave: Intercolonial Rivalry and Spanish Slave Policy, 1687-1764." In Samuel Proctor, ed. Eighteenth Century Florida and Its Borderlands Gainesville, FL: University Press of Florida, 1975.

Thornton, John K. Africa and Africans in the Making of the Atlantic World, 1400-1800. Cambridge: Cambridge University Press, 2nd expanded ed., 1998.

Timberlake, Henry. Memoirs of Lieut. Henry Timberlake . . London: J. Ridley, W. Nicoll, and C. Henderson, 1765.

Todd, Helen. Mary Musgrove: Georgia Indian Princess. Savannah, GA: Seven Oaks Publishing Co., 1981.

A Treaty Held with the Catawba and Cherokee Indians . . . February and March 1756. Williamsburg, VA: W. Hunter, 1756.

Watkins, Robert, and George Watkins, ed. Digest of the Laws of the State of Georgia ... Philadelphia: Aitken, 1800.

Wesley, John. The Letters of the Rev. John Wesley, A.M . . ., Vol 1. London: Epworth Press, 1931.

Wheeler, Roxann. The Complexion of Race: Categories of Difference in Eighteenth-Century British Culture. Philadelphia: University of Pennsylvania Press, 2000.

William Richardson Davie Papers, 1758-1819 Mission Journal, addresses as a letter to the Reverend Samuel Davies, Secretary, The Society for Managing the Mission and Schools among the Indians.

Williams, Samuel C. "Presbyterian Mission to the Cherokees, 1757-59." Tennessee Historical Magazine, 2nd Ser., 1 (1931): 125-138.

- "Christian Missions to the Overhill Cherokees." Chronicles of Oklahoma 12, no. 1 (March 1934): n.p.

Windley, Lathan A. Runaway Slave Advertisements: Georgia. Westport, CT: Greenwood Press, 1983.

Wood, Betty. Slavery in Colonial Georgia, 1730-1775. Athens, GA: University of Georgia Press, 1984.

Wood, Peter. Black Majority: Negroes in Colonial South Carolina from 1670 Through the Stono Rebellion. New York: Norton, 1974.

Wyss, Hilary E. Writing Indians: Literacy, Christianity, and Native Community in Early America. Amherst: University of Massachusetts Press, 2002.

Atkin, Edmond. Indians of the Southern Frontier: The Edmond Atkin Report and Plan of 1755. Wilbur R. Jacobs, ed. Columbia, SC: University of South Carolina Press, 1954. 
Bailyn, Bernard. Education in the Formation of American Society. Chapel Hill, NC: The University of North Carolina Press, 1970.

Bonnell, Victoria E., Lynn Hunt, and Richard Biernacki. Beyond the Cultural Turn: New Directions in the Study of Society and Culture. Berkeley, CA: University of California Press, 1999.

Brown, Richard Maxwell. The South Carolina Regulators. Cambridge: The Belknap Press of Harvard University Press, 1963.

Buckingham, Clyde. "Early American Orphanages: Ebenezer and Bethesda." Social Forces 26 (1948): 312.

Bushman, Richard. The Refinement of America: Persons, Houses, Cities. New York: Knopf, 1992.

Candler, Allen D. The Colonial Records of the State of Georgia. New York: AMS Press, 1970 [1904-1916].

Carr, Lois Green. "The Development of the Maryland Orphan's Court." In Aubrey C. Land et al., eds. Law, Society, and Politics in Early Maryland. Baltimore: John Hopkins University Press, 1977, 41-56.

Carson, Cary. "The Consumer Revolution in Colonial British America: Why Demand?" In Cary Carson, Ronald Hoffman, and Peter J. Albert, eds. Of Consuming Interests: The Style of Life in the Eighteenth Century. Charlottesville: University Press of Virginia and United States Capital Historical Society, 1994.

The Case of Orphans Consider'd, from Antiquity: With Some Remarks on our Courts of Wards, and Why Put Down: As also, on the Court of Chancery Having the Disposition of Orphans Money. London: Peele, 1725.

Chaplin, Joyce. An Anxious Pursuit: Agricultural Innovation and Modernity in the Lower South, 1730-1815. Chapel Hill, NC: University of North Carolina Press, 1993.

Chestnut College Collection on Bethesda. Savannah, GA: Georgia Historical Society.

Church, Robert L. et al., "The Metropolitan Experience in American Education." History of Education Quarterly 29 (1989): 419-446.

Clark, Elizabeth A. History, Theory, Text: Historians and the Linguistic Turn. Cambridge, MA: Harvard University Press, 2004.

Clark, Emily, and Virginia Meacham Gould. "The Feminine Face of Afro-Catholicism in New Orleans, 1727-1852." William and Mary Quarterly 59 (2002).

Coates, Timothy. Convicts and Orphans: Forced and State-Sponsored Colonizers in the Portuguese Empire, 1550-1750. Stanford, CA: Stanford University Press, 2002.

Collections of the Georgia Historical Society, Vol. VI, The Letters of the Hon. James Habersham, 1756-1775. Savannah: The Georgia Historical Society, 1904.

Cooper, Thomas, and David McCord, eds. The Statutes at Large of South Carolina: Edited under Authority of the Legislature. Columbia, SC: University of South Carolina Press, 1837.

Cremin, Lawrence A. American Education: The Colonial Experience, 16071783. New York: Harper \& Row, 1970.

Cross, Paul. Paul Cross Papers. Folder 4. South Caroliniana Library. Columbia, SC: University of South Carolina. 
ed. The Journal of the Commons House of Assembly, September 12, 1739-March 26, 1741. Columbia, SC: Historical Commission of South Carolina, 1952.

Easterby, J. H. “The South Carolina Education Bill of 1770." South Caronia Historical Magazine 48 (1947): 95-111.

Edwards, Newton, and Herman G. Richey. The School in the American Social Order: The Dynamics of American Education. Boston, MA: Houghton Mifflin, 1947.

Egerton, Douglas R. He Shall Go Out Free: The Lives of Denmark Vesey. Wisconsin: Madison House, 2000.

Egmont Manuscript Typescripts. Hargrett Reading Room, University of Georgia at Athens.

Foster, Gertrude, comp. "A Documentary History of Education in South Carolina as Revealed in the Manuscripts of the Society for the Propagation of the Gospel in Foreign Parts.” Ed.D., University of South Carolina, 1932.

Foucault, Michel. The History of Sexuality: Volume 1, an Introduction. Robert Hurley, trans. New York: Pantheon, 1978.

Franke. Pietas Hallensis ... Translated and Extracted in George Whitefield, A Continuation of the Account of the Orphan House in Georgia . . . London, 1743, 104-105.

Gavitt, Philip. Charity and Children in Renaissance Florence: The Ospedale degli Innocenti, 1410-1536. Ann Arbor, MI: University of Michigan Press, 1990.

George Whitefield, A Continuation of the Account of the Orphan House in Georgia ... London, 1743, 104-105.

Georgia Gazette [Savannah]

Gonaver, Wendy. "Race Relations: A Family Story, 1765-1867.” MA Thesis, College of William and Mary, 2001.

Greene, Jack. Pursuits of Happiness: The Social Development of Early Modern British Colonies and the Formation of American Culture. Chapel Hill, NC: University of North Carolina Press, 1988.

Habersham Family Papers. Savannah, GA: Georgia Historical Society.

Hadden, Sally E. Slave Patrols: Law and Violence in Virginia and the Carolinas. Cambridge: Harvard University Press, 2001.

Hammerer, John Daniel. An Account of a Plan for Civilizing the North American Indians: Proposed in the Eighteenth Century. Paul Leicester Ford, ed. Brooklyn: Historical Printing Club, 1890.

Hansen, William Albert. "John Wesley and the Rhetoric of Reform.” Ph.D. diss., University of Oregon, 1972.

Haviland, Thomas P. "Of Franklin, Whitefield, and Orphans.” Georgia Historical Quarterly 29 (December 1945).

Herkberg, Gustav Friedrich. August Hermann Franke und Sein Hallisches Waisenhaus. Halle: Verlag der Buchhandlung des Waisenhauses, 1898.

Horn, James. Adapting to a New World: English Society in the Seventeenth Century Chesapeake. Chapel Hill, NC: University of North Carolina Press, 1994.

Huger Family. Huger Family Papers. South Carolina, Charleston: South Carolina Historical Society.

Hunt, Lynn. ed. The New Cultural History. Berkeley: University of California Press, 1989. 
Jefferson, Thomas. The Works of Thomas Jefferson. Leicester, Paul, ed. New York: G.P. Putnam's Sons, 1905.

Jones, George Fenwick. The Georgia Dutch: From the Rhine and Danube to the Savannah, 1733-1783. Athens: University of Georgia Press, 1992.

—. "Two 'Salzburger' Letters from George Whitefield and Theobald Kiefer II.” The Georgia Historical Quarterly 62, no. 1 (1978): 50-57.

Jones, George Fenwick, and Marie Hahn, eds. Detailed Reports on the Salzburg Emigrants who Settled in America . . . Samuel Urlsperger, ed. Vol. 3, 1736. Athens: University of Georgia Press, 1972.

Jones Family. Jones Family Papers. Box 4, Folder 56. Georgia, Savannah: Georgia Historical Society.

Kaestle, Carl F. Pillars of the Republic: Common Schools and American Society, 1780-1860. New York: Hill and Wang, 1983.

Klein, Rachel. Unification of a Slave State: The Rise of the Planter Class in the South Carolina Backcountry, 1760-1808. Chapel Hill, NC: University of North Carolina Press, 1990.

La Vopa, Anthony J. Grace, Talent, and Merit: Poor Students, Clerical Careers, and Professional Ideology in Eighteenth-Century Germany. Cambridge: Cambridge University Press, 1988.

Lambert, Frank. “'Pedlar in Divinity': George Whitefield and the Great Awakening, 1737-1745." Journal of American History (December 1990).

Lane, Mills, ed. General Oglethorpe's Georgia: Colonial Letters, 1733-1743. Savannah, GA: Beehive Press, 1975.

Lavrin, Asuncion. Sexuality and Marriage in Colonial Latin America. Lincoln: University of Nebraska Press, 1989.

Livingston, Helen. "Thomas Morritt: Schoolmaster at the Charleston Free School, 1723-1728." Historical Magazine of the Protestant Episcopal Church 14 (1946).

Lockley, Timothy. Lines in the Sand: Race and Class in Lowcountry Georgia, 1750-1860. Athens: University of Georgia Press, 2001.

Lockridge, Kenneth. On the Sources of Patriarchal Rage: The Commonplace Books of William Byrd and Thomas Jefferson and the Gendering of Power in the Eighteenth Century. New York: New York University Press, 1992.

Mancall, Peter, Joshua Rosenbloom, and Thomas Weiss. "Conjectural Estimates of Economic Growth in the Lower South: 1720-1800." In William A. Sundstrom, et al., eds. History Matters: Essays on Economic Growth, Technology, and Demographic Change. Stanford, CA: Stanford University Press, 2003.

Manzione, Carol Kazmierczak. A Passing Charity: Christ's Hospital of London, 1552-1598 London: Susquehanna University Press, 1995.

McCants, Anne E. C. Civic Charity in a Golden Age: Orphan Care in Early Modern Amsterdam. Chicago: University of Illinois Press, 1997.

McCaul, Robert L. "A Documentary History of Education in Georgia." PhD. diss., University of Chicago, 1953.

—. "Education in Georgia During the Period of Royal Government, 17521776: Financial Support of Schools and Schoolmasters." GHQ 40 (June 1956): 103-112.

"Whitefield's Bethesda College Projects and Other Major Attempts to Found Colonial Colleges.” GHQ 44 (September 1960): 263-277. 
Monaghan, E. Jennifer. Learning to Read and Write in Colonial America. Amherst: University of Massachusetts Press, 2005.

Morgan, Edmund S. American Slavery, American Freedom: The Ordeal of Virginia. New York: Norton, 1975.

Morgan, Philip D. Slave Counterpoint: Black Culture in the Eighteenth-Century Chesapeake and Lowcountry. Chapel Hill, NC: University of North Carolina Press, 1998.

Murray, John E. "Literacy Acquisition in an Orphanage: A Historical Longitudinal Case Study.” American Journal of Education 110 (2004): 172-196.

Nelson, Dana. "Consolidating National Masculinity: Scientific Discourse and Race in the Post-Revolutionary United States." In Blair St. George, ed. Possible Pasts: Becoming Colonial in Early America. Ithaca, NY: Cornell University Press, 2000, 201-215.

Novoa, Antonio. “Texts, Images, Memories: Writing New Histories of Education." In Popkewitz, et al., eds., Cultural History and Education: Critical Essays on Knowledge and Schooling. New York: Routledge Publishing, 2001.

Olwell, Robert. Masters, Slaves, and Subjects: The Culture of Power in the South Carolina Low Country, 1740-1790. Ithaca, NY: Cornell University Press, 1998.

Opal, J. M. "Exciting Emulation: Academies and the Transformation of the Rural North, 1780s-1820s." Journal of American History 91 (2004): 445-470.

Pennington, Edgar Legare. "The Reverend Thomas Morritt and the Free School in Charleston." SCHM 32 (January 1931): 34-45.

Perdue, Theda. Cherokee Women: Gender and Culture Change, 1700-1835. Lincoln: University of Nebraska Press, 1998.

Reese, Trevor R. The Clamorous Malcontents: Criticisms and Defenses of the Colony of Georgia, 1741-1743. Savannah: Beehive Press, 1973.

Roediger, David. The Wages of Whiteness: Race and the Making of the American Working Class. New York: Verso, 1991.

Rogal, Samuel J. John and Charles Wesley. Boston: Twayne Publishers, 1983.

Rogers, George C. Charleston in the Age of the Pinckneys. Columbia, SC: University of South Carolina Press, 1980.

Roper, L. H. and Bertrand Van Ruymbeke, eds. Constructing Early Modern Empires: Proprietary Ventures and the Origins of the Atlantic World, 15001750. Boston: Brill, 2007.

Rules of the Society for the Relief of the Widows and Orphans of the Clergy of the Protestant Episcopal Church in the State of South-Carolina. United States South Carolina Charleston: Printed for the Society by A. E. Miller Charleston, 1813.

Safley, Thomas Max. Charity and Economy in the Orphanages of Early Modern Augsburg. Atlantic Highlands, New Jersey: Humanities Press, 1997.

Saunt, Claudio. A New Order of Things: Property, Power, and the Transformation of the Creek Indian, 1733-1816. New York: Cambridge University Press, 1999.

Sheehan, Bernard W. Seeds of Extinction. New York: W. W. Norton \& Company, 1974.

Smith, Henry. "The Town of Dorchester, in South Carolina: A Sketch of It's History." SCHM 6 (April 1905): 62-95.

South Carolina Gazette. 
South Carolina Gazette and Country Journal.

Spady, James O'Neil. "Bubbles and Beggars and the Bodies of Laborers: The Georgia Trusteeship's Colonialism Reconsidered.” In Constructing Early Modern Empires: Proprietary Ventures in the Atlantic World, 1500-1750. Leiden, The Netherlands: Brill, 2007.

Stevens/Sanders-Venning/Cogdell Papers. Library Company of Philadelphia. Philadelphia, PA.

Stoler, Ann Laura. Race and the Education of Desire: Foucault's History of Sexuality and the Colonial Order of Things. Durham, NC: Duke University Press, 1995.

Sundue, Sharon Braslaw. "Confining the Poor to Ignorance? Eighteenth Century American Experiments with Charity." History of Education Quarterly 47, no 2 (May 2007).

- Industrious in their Stations: Young People at Work in Early America. Charlottesville: University of Virginia Press, 2009.

Varela, Julia. "Genealogy of Education: Some Models of Analysis." In Popkewitz, et al., eds., Cultural History and Education: Critical Essays on Knowledge and Schooling. New York: Routledge Publishing, 2001, 107-124.

Walsh, Richard. Charleston's Sons of Liberty: A Study of the Artisans, 17631789. Columbia, SC: University of South Carolina Press, 1959.

Waring, Martha Gallaudet. "Savannah's Earliest Private Schools, 1733-1800.” GHQ 14 (December 1930): 41-57.

Watson, Alan D. "Orphanages in Colonial North Carolina: Edgecombe County as a Case Study." North Carolina Historical Review 52 (1975): 105-119.

Wesley, Charles. The Early Journal of Charles Wesley. John Telford, ed. London: Charles H. Kelly, 1909.

Wesley, John. The Journal of the Reverend John Wesley. Nehemiah Curnock, ed., Vol. 1. New York: Charles H. Kelly, 1909.

-. The Letters of the Rev. John Wesley, A.M . . ., Vol. 1. London: Epworth Press, 1931.

White, George. ed. and comp. Historical Collections of Georgia: Containing the Most Interesting Facts, Traditions, Biographical Sketches, Anecdotes, etc., Relating to its History and Antiquities, from its First Settlement to the Present Time. New York: Pudney \& Russell, 1854.

Whitfield, George. A Further Account of God's Dealings with the Reverend Mr. George Whitefield ... to which is Annex'd a Brief Account of the Rise, Progress, and Current Situation of the Orphan-House in Georgia in a Letter to a Friend. Philadelphia: Printed and sold by W. Bradford, 1746.

William A. Sundstrom, and Warren Whatley, eds. History Matters: Essays on Economic Growth, Technology, and Demographic Change. Stanford, CA: Stanford University Press, 2004.

Williams, Samuel C. "Presbyterian Mission to the Cherokees, 1757-59." Tennessee Historical Magazine, 2nd Ser., 1 (1931): 125-138.

- "Christian Missions to the Overhill Cherokees." Chronicles of Oklaboma 12, no. 1 (March 1934).

Wilson, Renate. Halle and Ebenezer: Pietism, Agriculture and Commerce in Colonial Georgia. Ph.D. diss., University of Maryland, 1988. 
. Pious Traders in Medicine: A German Pharmaceutical Network in Eighteenth-Century North America. State College: Pennsylvania State University Press, 2000.

Wood, Betty. Slavery in Colonial Georgia, 1730-1775. Athens: University of Georgia Press, 1984.

- Women's Work, Men's Work: The Informal Slave Economies of Lowcountry Georgia. Athens: University of Georgia Press, 1995.

Wood, Peter. Black Majority: Negroes in Colonial South Carolina from 1670 Through the Stono Rebellion. New York: Norton, 1974.

Woodmason, Charles. The Carolina Backcountry on the Eve of the Revolution: The Journal and Other Writings of Charles Woodmason. Richard James Hooker, ed. Chapel Hill, NC: University of North Carolina Press, 1953.

Woody, Thomas. History of Women's Education in the United States. Vol. 2. New York: The Science Press, 1929.

An Act for Making Provision for the Civilization of the Indian Tribes Adjoining the Frontier Settlements, 30 March 1802. U.S. Statutes at Large 3 (1819): 516-517.

Alderson, Robert. "Charleston's Rumored Slave Revolt of 1793.” In David Geggus, ed. The Impact of the Haitian Revolution on the Atlantic World. Columbia, SC: University of South Carolina Press, 2001, 93-111.

Baptist, Edward E. The Half Has Never Been Told: Slavery and the Making of American Capitalism. New York: Basic Books, 2014.

Barnwell, Joseph W. "The Evacuation of the British in 1782." South Carolina Historical and Genealogical Magazine 11 (1910): 1-26.

Beaver, R. Pierce. Church, State, and the American Indians. St. Louis: Concordia Publishing House, 1966.

Beckert, Sven. The Empire of Cotton: A Global History. New York: Alfred A. Knopf, 2014.

Bellows, Barbara L. Benevolence among Slaveholders: Assisting the Poor in Charleston, 1670-1860. Baton Rouge: Louisiana State University Press, 1993.

Berkhofer, Robert. Salvation and the Savage: An Analysis of Protestant Missions and American Indian Response, 1787-1862. Lexington: University of Kentucky Press, 1965.

Brunhouse, Robert H., ed. "David Ramsay, 1749-1815." Transactions of the American Philosophical Society 55 (1965).

Calhoun, John C., Robert Lee Meriwether, William Edwin Hemphill, and Clyde Norman Wilson. The Papers of John C. Calhoun. Columbia, SC: Published by the University of South Carolina Press for the South Caroliniana Society, 1959.

Calhoun, John C., and Richard K. Crallé. The Works of John C. Calhoun. New York: D. Appleton and Company, 1855.

Calloway, Colin G. The American Revolution in Indian Country: Crisis and Diversity in Native Communities. New York: Cambridge University Press, 1995.

Caughey, John Walton. McGillivray of the Creeks. Norman: University of Oklahoma Press, 1938.

Elias Cornelius Papers, 1816-1832. Library Service Center Box 1, c.1. Duke University Special Collections. Durham, North Carolina.

Fox, Adam. Oral and Literate Culture in England, 1500-1700. Oxford: Oxford University Press, 2000. 
Frey, Sylvia. Water from the Rock: Black Resistance in a Revolutionary Age. Princeton, NJ: Princeton University Press, 1991.

Gazette of the State of Georgia.

Gilmer, Francis Walker. Notebook and Journal. 1815-1822. Library Service Center S:927. Duke University Special Collections. Durham, North Carolina.

Green, Andy. Education and State Formation: Europe, East Asia and the USA. Palgrave Macmillan Houndmills, Basingstoke, Hampshire: Palgrave Macmillan, 2013.

Green, Michael D. The Politics of Indian Removal: Creek Government and Society in Crisis. Lincoln, NB: University of Nebraska Press, 1982.

Hawkins, Benjamin. Letters of Benjamin Hawkins: 1796-1806. Stephen B. Weeks, ed. Collections of the Georgia Historical Society. Vol. 9. Savannah: Georgia Historical Society, 1916.

History of the Baptist Denomination in Georgia. Atlanta, GA: J.P. Harrison \& Co, 1881.

Holton, Woody. Forced Founders: Indians, Debtors, Slaves, and the Making of the American Revolution in Virginia. Chapel Hill, NC: University of North Carolina Press, 1999.

Horsman, Reginal. "American Indian Policy and the Origins of Manifest Destiny." University of Birmingham Historical Journal 11 (1968): 130-139.

King, Spencer B. Jr. Georgia Voices: A Documentary History to 1872. Athens: University of Georgia Press, 1966.

Knox, William. "Knox to Governor William Blount [Tennessee] April 22, 1792." In F. P. Prucha ed., American Indian Policy in the Formative Years. Lincoln: University of Nebraska Press, 1970.

Lee, Erika. At America's Gates: Chinese Immigration During the Exclusion Era, 1882-1943. Chapel Hill, NC: University of North Carolina Press, 2003.

McKenzie, Beatrice. "Gender and United States Citizenship in Nation and Empire." History Compass 4, no. 3 (2006): 592-602.

McMillin, James A. The Final Victims: Foreign Slave Trade to North America, 1783-1810. Columbia, SC: University of South Carolina Press, 2004.

Parkinson, Robert G. The Common Cause: Creating Race and Nation in the American Revolution. Chapel Hill, NC: University of North Carolina Press, 2016.

Pierce, Alfred M. A History of Methodism in Georgia: 1736-1955. Atlanta: North Georgia Conference Historical Society, 1956.

Roediger, David. The Wages of Whiteness: Race and the Making of the American Working Class. New York: Verso, 1991.

Salzillo, Frederick A. Jr. "Economic and Political Foundations of Educational Reform Activity in Georgia, 1830-1840.” MA Ed, Georgia State University, 1973.

Satz, Ronald N. American Indian Policy in the Jacksonian Era. Lincoln, NE: University of Nebraska Press, 1975.

Sheehan, Bernard W. Seeds of Extinction. New York: W. W. Norton \& Company, 1974.

Shy, John W. A People Numerous and Armed. Ann Arbor, MI: University of Michigan Press, 1990.

Sinha, Manisha. The Slave's Cause: A History of Abolition. New Haven: Yale University Press, 2016. 
Taggart, Robert J. Private Philanthropy and Public Education. Newark, DE: University of Delaware Press, 1988.

Washington, George. "Circular to the State Governments." Newburgh, June 8, 1783, In Joseph Rhodehamel, comp., George Washington: Writings. New York: Library of America, 1997.

Watkins, Robert, and George Watkins, ed. and comp. Digest of the Laws of the State of Georgia ... Philadelphia: Aitken, 1800.

Willis, William S. "Divide and Rule: Red, White and Black in the Southeast." The Journal of Negro History 48, no. 3 (July 1962, 1970).

Wilms, Douglas C. "Cherokee Land Use in Georgia before Removal." In William L. Anderson, ed. Cherokee Removal: Before and After. Athens: University of Georgia Press, 1991, 1-28.

An Act for Making Provision for the Civilization of the Indian Tribes Adjoining the Frontier Settlements, 30 March 1802. U.S. Statutes at Large 3 (1819): 516-517.

Adair, James, and Samuel Cole Williams. Adair's History of the American Indians. New York: Published for University Microfilms, Ann Arbor by Argonaut Press, 1966.

Alderson, Robert. “Charleston's Rumored Slave Revolt of 1793.” In David Geggus, ed. The Impact of the Haitian Revolution on the Atlantic World. Columbia, SC: University of South Carolina Press, 2001, 93-111.

Anon. "Nancy Ward, War Woman.” Cherokee Quarterly 1, no. 4 (Fall 1997): n.p.

Barnwell, Joseph W. "The Evacuation of the British in 1782." South Carolina Historical and Genealogical Magazine 11 (1910): 1-26.

Beckert, Sven. The Empire of Cotton: A Global History. New York: Alfred A. Knopf, 2014.

Benjamin Hawkins Papers, 1790-1813. Savannah, GA: Georgia Historical Society.

Bhabha, Homi K. The Location of Culture. New York: Routledge, 1994.

Boudinot, Elias. Poor Sarah, or the Benefits of Religion Exemplified in the Life and Death of an Indian Woman. n.p., 1818.

- Cherokee Editor: The Writings of Elias Boudinot. Theda Perdue ed. Knoxville: University of Tennessee Press, 1983.

Brainerd Mission School Account Book, Volume 1, 1819-1854. Morrow, GA: Georgia Archives.

Braund, Kathryn E. Holland. "Guardians of Tradition and Handmaidens to Change: Women's Roles in Creek Economic and Social Life During the Eighteenth Century." American Indian Quarterly 14 (1990): 239-258.

- Deerskins and Duffels: The Creek Indian Trade with Anglo America, 1685-1815. Lincoln: University of Nebraska Press, 1993.

Brickell, John. The Natural History of North Carolina. Dublin, 1737 [1969 reprint].

Brown, Catharine. Memoir of Catharine Brown, A Christian Indian, of the Cherokee Nation. William Hoole, ed. University, AL: Confederate Publishing, 1986.

Bryan, Andrew. "Andrew Bryan to Reverend Brother, Savannah, December 23, 1800." The Journal of Negro History 1 (January 1916).

Candler, Allen D. The Colonial Records of the State of Georgia. New York: AMS Press, 1970 [1904-1916]. 
Caughey, John Walton. McGillivray of the Creeks. Norman: University of Oklahoma Press, 1938.

Clarke, Jonathan. "Jonathan Clarke to Brother Rippon, Savannah, December 22, 1792." The Journal of Negro History 1 (January 1916).

Clay, Thomas S. Detail of a Plan for the Moral Improvement of Negroes on Plantations. Savannah, GA: Georgia Historical Society, NP, 1833.

Collins, Linton McGee. "The Activities of the Missionaries among the Cherokees.” Georgia Historical Quarterly 6 (1922).

David Henley to James Robertson, Nashville, June 19, 1797. From Duke University Special Collections, David Henley Papers, 1791-1817.

Davis, Harold E. The Fledgling Province: Social and Cultural Life in Colonial Georgia, 1733-1776. Chapel Hill, NC: University of North Carolina Press, 1976.

Devens, Carol. Countering Colonization: Native American Women and Great lakes Missions, 1630-1900. Berkeley: University of California Press, 1990.

Donohoe, Felicity. “'Decoying them Within': Creek Gender Identities and the Subversion of Civilization." In Gregory D. Smithers and Brooke N. Newman, eds. Native Diasporas: Indigenous Identities and Settler Colonialism in the Americas. Lincoln, NE: University of Nebraska Press, 2014, 187-205.

Easterby, J. H., ed. The Journal of the Commons House of Assembly, September 12,1739-March 26, 1741. Columbia, SC: Historical Commission of South Carolina, 1952.

Egerton, Douglas R. He Shall Go Out Free: The Lives of Denmark Vesey. Wisconsin: Madison House, 2000.

Elias Cornelius Papers, 1816-1829. Duke University Special Collections Library.

Foucault, Michel. Discipline and Punish: The Birth of the Prison. Alan Sheridan, trans. New York: Pantheon, 1977.

Frey, Sylvia. Water from the Rock: Black Resistance in a Revolutionary Age. Princeton, NJ: Princeton University Press, 1991.

Frey, Sylvia, and Betty Wood. Come Shouting to Zion: African American Protestantism in the American South and British Caribbean to 1830. Chapel Hill, NC: University of North Carolina Press, 1998.

Gardner, Robert G. "Primary Sources in the Study of Eighteenth Century Georgia Baptist History." Viewpoints. Georgia Baptist History 7 (1980): 59-118.

Gazette of the State of Georgia.

Georgia Gazette. Savannah.

Gilmer, Francis Walker. Notebook and Journal. 1815.

Gonaver, Wendy. "Race Relations: A Family Story, 1765-1867.” MA Thesis, College of William and Mary, 2001.

Green, Michael D. The Politics of Indian Removal: Creek Government and Society in Crisis. Lincoln, NE: University of Nebraska Press, 1982.

Gundaker, Grey. Signs of Diaspora, Diaspora of Signs: Literacies, Creolization, and Vernacular Practice in African America. New York: Oxford University Press, 1998.

Hawkins Family Papers. Chapel Hill, NC: University of North Carolina, Southern Historical Collection, Wilson Library, University of North Carolina at Chapel Hill. 
Hawkins, Benjamin. Letters of Benjamin Hawkins: 1796-1806. Stephen B. Weeks, ed. Collections of the Georgia Historical Society. Vol. 9. Savannah: Georgia Historical Society, 1916.

Higginbotham, Mary A. "The Creek Path Mission.” Journal of Cherokee Studies (Fall 1976): 72-86.

Hitchcock, Ethan Allen. A Traveler in Indian Territory . . . Grant Foreman, ed. Cedar Rapids, Iowa: Torch Press, 1930.

Hodgson, Adam. Remarks during a Journey through North America . . . Westport, Connecticut: Negro Universities Press, 1970 [1823].

Holland, Edwin Clifford. A Refutation of the Calumnies Circulated against the Southern and Western States ... Charleston, 1822.

Jeremiah Evarts Diary, April 30, 1822. From Georgia Historical Society, ErwinFloyd Papers.

John Johnson Papers, Official journal, 1791-1792. Georgia Historical Society.

Johnson, Michael. "Denmark Vesey and His Co-Conspirators." William and Mary Quarterly, 3rd Ser., 58 (2001).

Jones, Charles C. Tenth Annual Report of the Association for the Religious Instruction of the Negroes in Liberty County, Georgia. Savannah: P.G. Thomas, 1845. Savannah, GA: Georgia Historical Society.

Landers, Jane. "Gracia Real de Santa Maria de Mose: A Free Black Town in Spanish Colonial Florida.” American Historical Review 95 (1990): 9-30.

- "Spanish Sanctuary: Fugitives in Florida, 1687-1790." Florida Historical Quarterly 42 (1984): 296-313.

Laurens, Henry, Philip M. Hamer, George C Rogers, and David R. Chesnutt. The Papers of Henry Laurens. Columbia, SC: Published for the South Carolina Historical Society by the University of South Carolina Press, 1968-2003.

Liele, George. "George Liele to unknown, Kingston, December 18, 1791.” Journal of Negro History 1 (1916): 71-74.

Littlefield, Daniel F. Africans and Creeks: From the Colonial Period to the Civil War. Westport, CT: Greenwood Press, 1979.

Loulie Latimer Owens. "Baptist Church Female Mite Societies.” Unpublished ms: South Caroliniana Library, 1950.

Lyons, Scott R. X-Marks: Native Signatures of Assent. Minneapolis: University of Minnesota Press, 2010.

MacKee, John. Diary, September 7, 1804. From Southern Historical Collection, MacKee Papers. Chapel Hill, NC: University of North Carolina.

Martin, Joel W. Sacred Revolt: The Muskogees' Struggle for a New World. Boston: Beacon Press, 1993.

Mauelshagen, Carl, and Gerald H. Davis, eds. and trans. Partners in the Lord's Work: The Diary of the Two Moravian Missionaries in the Creek Indian Country, 1807-1813. Atlanta: Georgia State College, 1969.

Morgan, Philip D. Slave Counterpoint: Black Culture in the Eighteenth-Century Chesapeake and Lowcountry. Chapel Hill, NC: University of North Carolina Press, 1998.

Moulder, M. Amanda. "Cherokee Practice, Missionary Intentions: Literacy Learning among Early Nineteenth-Century Cherokee Women.” College Composition and Communication 63, no. 1 (2011): 75-97.

Murphy, Lucy Eldersveld. "Autonomy and Economic Roles of Indian Women of the Fox-Wisconsin River Region, 1763-1832." In Nancy Shoemaker, ed. 
Negotiators of Change: Historical Perspectives on Native American Women. New York: Routledge, 1995.

Paquette, Robert. "From Rebellion to Revisionism: The Continuing Debate about the Denmark Vesey Affair." Journal of the Historical Society 4 (Fall 2004).

Paquette, Robert, and Douglas R. Egerton. "Of Facts and Fables: New Light on the Denmark Vesey Affair." The South Carolina Historical Magazine 105 (2004).

Patterson, Orlando. Slavery and Social Death: A Comparative Study. Cambridge, MA: Harvard University Press, 1982.

Perdue, Theda. Cherokee Women: Gender and Culture Change, 1700-1835. Lincoln, NE: University of Nebraska Press, 1998.

Phillips, Joyce B., and Paul Gary Phillips. The Brainerd Journal: A Mission to the Cherokees, 1817-1823. Lincoln, NE: University of Nebraska Press, 1999.

Pope, John. A Tour Through the Southern and Western Territories of the United States. Richmond: John Dixon, 1792.

Pound, Merritt B. Benjamin Hawkins-Indian Agent. Athens: Georgia State College Press, 1951.

Return, J. Meigs Papers, 1802-1814. Duke University Special Collections Library. Richard Furman Papers. Columbia, SC: South Caroliniana Library, University of South Carolina.

Round, Phillip H. Removable Type: Histories of the Book in Indian Country, 1663-1880. Chapel Hill, NC: University of North Carolina Press, 2010.

Saunt, Claudio. A New Order of Things: Property, Power, and the Transformation of the Creek Indian, 1733-1816. New York: Cambridge University Press, 1999.

Smallwood, Stephanie. Saltwater Slavery: A Middle Passage from Africa to American Diaspora. Cambridge: Harvard University Press, 2007.

Spady, James O’Neil. "Power and Confession: On the Credibility of the Earliest Reports of the Denmark Vesey Conspiracy." William and Mary Quarterly, 3rd Ser., 68 (2011): 287-304.

Spivak, Gayatri. "Can the Subaltern Speak?” In Cary Nelson and Larry Grossberg, eds. Marxism and the Interpretation of Culture. Chicago: University of Illinois Press, 1988, 271-313.

Stuart, James. Three Years in North America. New York, 1833.

TePaske, John J. "The Fugitive Slave: Intercolonial Rivalry and Spanish Slave Policy, 1687-1764." In Samuel Proctor, ed. Eighteenth Century Florida and Its Borderlands. Gainesville: University Presses of Florida, 1975.

Timberlake, Henry. Memoirs of Lieut. Henry Timberlake . . London: J. Ridley, W. Nicoll, and C. Henderson, 1765.

Waldstreicher, David. In the Midst of Perpetual Fetes: The Making of American Nationalism, 1776-1820. Chapel Hill, NC: University of North Carolina Press, 1997.

Weaver, Jace. That the People Might Live: Native American Literatures and Native American Community. New York: Oxford University Press, 1997.

Wilms, Douglas C. "Cherokee Land Use in Georgia before Removal.” In William L. Anderson, ed. Cherokee Removal: Before and After. Athens: University of Georgia Press, 1991, 1-28.

Windley, Lathan A. Runaway Slave Advertisements: Georgia. Westport, CT: Greenwood Press, 1983. 
Acts of the General Assembly of the State of Georgia . . 1829. Milledgeville: Camak \& Ragland, 1830.

Acts of the General Assembly of the State of Georgia . . Morrow, GA: Georgia Archives.

Anonymous. "Upon Virtue in General, and Female Education and Manners in Particular: Being an Inaugural Dissertation to the Opening an English Academy for young Ladies \& Misses in Savannah the 26th Nov. 1786." Savannah, GA: Georgia Historical Society.

Arthur, Linda L. "A New Look at Schooling and Literacy: The Colony of Georgia." Georgia Historical Quarterly 84, no. 4 (Winter 2000): 563-589.

Baldwin, Abraham. "Speech to the University of Georgia Trustees." (February 28, 1785) Georgia Historical Quarterly 10 (1926): 327-328, 332.

Beaver, R. Pierce. Church, State, and the American Indians. St. Louis: Concordia Publishing House, 1966.

Bonner, James C., and Lucien E. Roberts, eds. Studies in Georgia History and Government. Spartanburg, SC: The Reprint Company, 1974.

Boogher, Elbert. Secondary Education in Georgia, 1732-1858. Philadelphia, PE: University of Pennsylvania Press, 1933.

Boucher, Richard. A View of the Causes and Consequences of the American Revolution. London, 1797.

Busik, Sean R. A Sober Desire for History: William Gilmore Simms as Historian. Columbia, SC: University of South Carolina Press, 2004.

Calhoun, John C. (John Caldwell), 1782-1850. The Papers of John C. Calhoun. Columbia, SC: Published by the University of South Carolina Press for the South Caroliniana Society, 1959.

Camden Orphan Society Daybook, 1797-1815. Columbia, SC: University of South Carolina, South Caroliniana Library.

Cashin, Edward. The Quest: A History of Public Education in Richmond County. Columbia, SC, 1985.

- Beloved Bethesda: A History of George Whitefield's Home for Boys, 1740-2000. Macon, GA: Mercer University Press, 2001.

Chaplin, Joyce. An Anxious Pursuit: Agricultural Innovation and Modernity in the Lower South, 1730-1815. Chapel Hill, NC: University of North Carolina Press, 1993.

Charleston Courier.

Charlton, Kenneth. "Mothers as Educative Agents in Pre-industrial England." History of Education 23, no. 2 (June 1, 1994): 129-156.

Chattooga County Poor School Records, 1800s-1900s. Morrow, GA: Georgia Archives.

City Gazette and Commercial Daily Advertiser. Charleston.

City Gazette and Daily Advertiser. Charleston.

Columbian Museum and Savannah Advertiser. Georgia.

DeBow, J. D. B. The Seventh Census of the United States: 1850. Washington: Robert Armstrong, 1853.

The Directory and Stranger's Guide for the City of Charleston: Also a Directory for Charleston Neck between Boundary-Street and the Lines: For the Year 1819. Charleston, SC: Schenck \& Turner; Charleston: A.E. Miller, 1981.

Dugas Papers. Savannah, GA: Georgia Historical Society. 
Easterby, J. H. History of the St Andrew's Society of Charleston, South Carolina. Charleston, SC: The Society, 1929.

Edward Oxford Papers. Morrow, GA: Georgia Archives.

Egerton, Douglas R. He Shall Go Out Free: The Lives of Denmark Vesey. Wisconsin: Madison House, 2000.

Ellicott, Andrew. The Journal of Andrew Ellicott . . . Philadelphia: Budd and Bartram, 1803.

Fellowship Society Records. Charleston, SC: College of Charleston Libraries.

Flinn, Andrew. "An Anniversary Address before the Charleston Orphan House." (unpublished ms., 1813). Columbia, SC: University of South Carolina, South Caroliniana Library.

Ford, Lacy K. Origins of Southern Radicalism: The South Carolina Upcountry, 1800-1860. New York: Oxford University Press, 1988.

Fort, Bruce "The Politics and Culture of Literacy in Georgia, 1800-1920.” Ph.D. diss., University of Virginia, 1999.

General Assembly Papers. Columbia, SC: South Carolina Department of Archives and History.

Georgetown Gazette. South Carolina.

Georgia Gazette. Savannah.

Georgia General Assembly. Journal of the Senate of the State of Georgia. Hapeville, GA: Longino and Porter, 1821.

Georgia State Gazette and Independent Register. Augusta.

Gillespie, Michele. Free Labor in an Unfree World: White Artisans in Slaveholding Georgia, 1789-1860. Athens: University of Georgia Press, 2000.

Gonaver, Wendy. "Race Relations: A Family Story, 1765-1867.” MA Thesis, College of William and Mary, 2001.

Green, Michael D. The Politics of Indian Removal: Creek Government and Society in Crisis. Lincoln, NE: University of Nebraska Press, 1982.

Guilds, John Caldwell. Simms: A Literary Life. Fayetteville: University of Arkansas Press, 1992.

Hadden, Sally E. Slave Patrols: Law and Violence in Virginia and the Carolinas. Cambridge: Harvard University Press, 2001.

Henry County Academies. Morrow, GA: Georgia Archives.

Hilton, Mary, Styles Morage, and Victor Watson. Opening the Nursery Door: Reading, Writing and Childhood: 1600-1900. London: Routledge, 1997.

Hrabowski, Richard. Directory for the District of Charleston: Comprising the Places of Residence and Occupation of the White Inhabitants of the Following Parishes. Charleston, SC: Printed by John Hoff, for Richard Hrabowski, 1809.

Huger Family Papers. Charleston, SC: South Carolina Historical Society.

Hughes-Folsom Papers. Savannah, GA: Georgia Historical Society.

James Habersham to Lady Huntington, Savannah, [illeg date], 1773. Chestnut College Collection.

James Jackson Papers, 1781-1796. Savannah, GA: Georgia Historical Society. Jasper County Academies. Morrow, GA: Georgia Archives.

Jeremiah Evarts Diary, April 30, 1822. From Georgia Historical Society, ErwinFloyd Papers.

John Johnson Papers, Official journal, 1791-1792. Georgia Historical Society. Johnson, John. The Rape of Bethesda; or The Georgia Orphan House Destroyed: A Poem. Charleston: Markland and McIver, 1792. 
Johnson, Michael. "Denmark Vesey and His Co-Conspirators." William and Mary Quarterly, 3rd Ser., 58 (2001).

Joiner, Oscar H., James C. Bonner, H. S. Shearouse, and T. E. Smith. A History of Public Education in Georgia, 1734-1976. Columbia, SC: R.L. Bryan Co, 1979.

Jones County Poor Schools. Morrow, GA: Georgia Archives.

Kaestle, Carl F. Pillars of the Republic: Common Schools and American Society, 1780-1860. New York: Hill and Wang, 1983.

Kennedy, Lionel Henry. An Oration Delivered in St. Philip's Church; Before the Inhabitants of Charleston, South-Carolina. On Monday the Fifth of July, 1813 (The Fourth Being Sunday), in Commemoration of American Independence . . . Charleston: W.P. Young, 44 Broad-Street, 1813.

King, Spencer B. Jr. Georgia Voices: A Documentary History to 1872. Athens: University of Georgia Press, 1966.

Klein, Rachel. Unification of a Slave State: The Rise of the Planter Class in the South Carolina Backcountry, 1760-1808. Chapel Hill, NC: University of North Carolina Press, 1990.

Knight, Edgar W. Public Education in the South. Boston: Ginn \& Co. 1922.

- A Documentary History of Education in the South before 1860, 5 vols. Chapel Hill, NC: University of North Carolina Press, 1950.

Lawrence Allen Papers. Columbia, SC: University of South Carolina, South Caroliniana Library.

Lilla M. Hawes. “Miscellaneous Papers of James Jackson, 1781-1798.” GHQ 37, no. 2 (1953): 147-149.

Lockley, Timothy. Lines in the Sand: Race and Class in Lowcountry Georgia, 1750-1860. Athens: University of Georgia Press, 2001.

Margaret Floyd to Lady Huntington, n.d., n.p. [aft June 1782]. Chestnut College Collection.

Mavor, William F. Historical Account of the Most Celebrated Voyages, Travels, and Discoveries: From the Time of Columbus to the Present Period. London: Printed for E. Newbery, 1797.

McCurry, Stephanie. Masters of Small Worlds: Gender Relations, Yeoman Households and the Political Culture of the South Carolina Lowcountry. Oxford: Oxford University Press, 1995.

McIntosh County Academy and Free School Accounts, 1821-1827. Morrow, GA: Georgia Archives.

McIntosh County Academy Minutes, 1820-1875. Morrow, GA: Georgia Archives, n.p.

Middleton, Henry. Legislature of South Carolina: Message of His Excellency the Governor, Delivered to the Legislature of South Carolina, the 26th of Nov., 1811. Baltimore: H. Niles, 1811.

Minutes of the Richmond County Academy Trustees. Special Collections, Reese Library, Augusta State University.

"Minutes of the Board of Trustees for Establishing a Public School in Lancaster District and of the Trustees of Escheated Property, August 30, 1800-April 15, 1840." General Assembly Committee Reports. Columbia, SC: South Carolina Department of Archives and History. 
"Montgomery County, Ga. Poor or Common School Records, 1835-1840." Photostat, Georgia Department of Archives and History. Morrow, GA: Georgia Archives, n.d.

Morgan, Philip D. Slave Counterpoint: Black Culture in the Eighteenth-Century Chesapeake and Lowcountry. Chapel Hill, NC: University of North Carolina Press, 1998.

Mount Zion Society Papers. Columbia, SC: University of South Carolina, South Caroliniana Library.

Mrs. E.H. Steele Papers. Savannah, GA: Georgia Historical Society.

Murray, John E. The Charleston Orphan House: Children's Lives in the First Public Orphanage in America. Chicago: University of Chicago Press, 2013.

- "Literacy Acquisition in an Orphanage: A Historical Longitudinal Case Study." American Journal of Education 110 (2004): 172-196.

Nash, Margaret A. "Rethinking Republican Motherhood: Benjamin Rush and the Young Ladies' Academy of Philadelphia." Journal of the Early Republic 17, no. 2 (Summer 1997): 171-191.

Onuf, Peter S. Jefferson's Empire: The Language of American Nationhood. Charlottesville: University Press of Virginia, 2000.

Orr, Dorothy. A History of Education in Georgia. Chapel Hill: The University of North Carolina Press, 1950.

Paquette, Robert. "From Rebellion to Revisionism: The Continuing Debate About the Denmark Vesey Affair." Journal of the Historical Society 4 (Fall 2004).

Paquette, Robert, and Egerton, Douglas R. "Of Facts and Fables: New Light on the Denmark Vesey Affair." The South Carolina Historical Magazine 105 (2004).

Perry, Mark. Lift Up Thy Voice: The Grimke Family's Journey From Slaveholders To Civil Rights Leaders. New York: Penguin, 2003.

Petitions of the General Assembly. Columbia, SC: South Carolina Department of Archives and History.

Pioneer and Yorkville Adviser.

Poor and Academy School Lists, Executive Department. Morrow, GA: Georgia Archives.

Report of the Commissioners of the Lexington Free School, 1812. Columbia, SC: South Carolina Department of Archives and History.

Richmond County, Poor Schools Book, 1854-1856. Morrow, GA: Georgia Archives.

Rudisill, Horace Fraser, ed. Minutes of the Saint David's Society, 1777-1835. Florence, SC: The Society, 1986.

Salzillo, Frederick A. Jr. "Economic and Political Foundations of Educational Reform Activity in Georgia, 1830-1840.” MA Ed, Georgia State University, 1973.

Savannah Freeschool Minutes. Vol. 1, 1816-1838. Savannah, GA: Georgia Historical Society.

Schoepf, Johann David. Travels in the Confederation [1783-1784]. Alfred J. Morrison, trans. and ed. Philadelphia: William J. Campbell, 1911.

Slappye, George H. "Early Foundations of Georgia's System of Common School Education.” Georgia Historical Quarterly 14 (June 1930): 139-149.

South Carolina Gazette. Columbia. 
South Carolina General Assembly. Journal of the Senate of the State of South Carolina. Columbia, 1800.

Stevens/Sanders-Venning/Cogdell Papers. Library Company of Philadelphia.

Sundue, Sharon Braslaw. "Confining the Poor to Ignorance? Eighteenth Century American Experiments with Charity." History of Education Quarterly 47, no 2 (May 2007).

Taggart, Robert J. Private Philanthropy and Public Education. Newark, DE: University of Delaware Press, 1988.

Thompson, John Furman. Foundations of the Public Schools in South Carolina. Columbia: The State Company, 1925.

Toomey Collection. Morrow, GA: Georgia Archives.

Virginia Steele Wood, McIntosh County Academy, McIntosh County, Georgia: Minutes of the Commissioners (1820-1875), Account Book of Students (1821-1834). Belmont, MA: Greenwood Press, 1973.

Walter C. Hartridge Collection. Savannah, GA: Georgia Historical Society.

Watkins, Robert, and George Watkins, ed. and comp. Digest of the Laws of the State of Georgia . . . Philadelphia: Aitken, 1800.

Whitescarver, Keith. "Creating Citizens for the Republic: Education in Georgia, 1776-1810." Journal of the Early Republic 13 (Winter 1993): 455-479.

Wilms, Douglas C. “Cherokee Land Use in Georgia before Removal.” In William L. Anderson, ed. Cherokee Removal: Before and After. Athens: University of Georgia Press, 1991, 1-28.

Woody, Thomas. History of Women's Education in the United States. Vol. 2. New York: The Science Press, 1929.

Zagarri, Rosemarie. "Gender and the New Liberal Synthesis.” American Quarterly 53, no. 1 (2001): 123-130.

Zboray, Ronald J. A Fictive People: Antebellum Economic Development and the American Reading Public. New York: Oxford University Press, 1993.

Agamben, Giorgio. State of Exception. Chicago: University of Chicago Press, 2005.

Bailyn, Bernard. Education in the Formation of American Society. Chapel Hill, NC: The University of North Carolina Press, 1970.

Baptist, Edward E. The Half Has Never Been Told: Slavery and the Making of American Capitalism. New York: Basic Books, 2014.

Baptist, Edward E, and Stephanie M. H. Camp. New Studies in the History of American Slavery. Athens: University of Georgia Press, 2006.

Bellows, Barbara L. Benevolence Among Slaveholders: Assisting the Poor in Charleston, 1670-1860. Baton Rouge: Louisiana State University Press, 1993.

Chaplin, Joyce. An Anxious Pursuit: Agricultural Innovation and Modernity in the Lower South, 1730-1815. Chapel Hill, NC: University of North Carolina Press, 1993.

City Gazette and Daily Advertiser. Charleston.

Coclanis, Peter A. The Shadow of a Dream: Economic Life and Death in the South Carolina Low Country, 1670-1920. New York: Oxford University Press, 1989.

Deloria, Vine. Custer Died for Your Sins: An Indian Manifesto. New York: Macmillan Company, 1969. 
Eelman, Bruce W. “ ‘An Educated and Intelligent People Cannot Be Enslaved’: The Struggle for Common Schools in Antebellum Spartanburg, South Carolina." History of Education Quarterly 44, no. 2 (2004): 250-270.

Fiskesjo, M. "Outlaws, Barbarians, Slaves: Critical Reflections on Agamben's Homo Sacer." Hau: Journal of Ethnographic Theory 2, no. 1 (2012): 161-180.

Frey, Sylvia. Water from the Rock: Black Resistance in a Revolutionary Age. Princeton, NJ: Princeton University Press, 1991.

Greene, Jack. Pursuits of Happiness: The Social Development of Early Modern British Colonies and the Formation of American Culture. Chapel Hill, NC: University of North Carolina Press, 1988.

Hoffman, Ronald, and Peter J. Albert. The Transforming Hand of Revolution: Reconsidering the American Revolution As a Social Movement. Charlottesville, VA: University Press of Virginia, 1996.

Holton, Woody. Forced Founders: Indians, Debtors, Slaves, and the Making of the American Revolution in Virginia. Chapel Hill, NC: University of North Carolina Press, 1999.

Jameson, J. Franklin. The American Revolution Considered as a Social Movement. Princeton, NJ: Princeton University Press, 1973 [1926].

Jennings, Francis. The Invasion of America: Indians, Colonialism, and the Cant of Conquest. Chapel Hill, NC: University of North Carolina Press, 1975.

Kaestle, Carl F. The Evolution of an Urban School System: New York City, 17501850. Cambridge: Harvard University Press, 1973.

- Pillars of the Republic: Common Schools and American Society, 17801860. New York: Hill and Wang, 1983.

Monaghan, E. Jennifer. Learning to Read and Write in Colonial America. Amherst: University of Massachusetts Press, 2005.

Morgan, Edmund S. American Slavery, American Freedom: The Ordeal of Virginia. New York: Norton, 1975.

Morgan, Philip D. Slave Counterpoint: Black Culture in the Eighteenth-Century Chesapeake and Lowcountry. Chapel Hill, NC: University of North Carolina Press, 1998.

Smallwood, Stephanie. Saltwater Slavery: A Middle Passage from Africa to American Diaspora. Cambridge: Harvard University Press, 2007.

Sundue, Sharon Braslaw. Industrious in their Stations: Young People at Work in Early America. Charlottesville: University of Virginia Press, 2009.

Sweet, John Wood. Bodies Politic: Negotiating Race in the American North, 1730-1830. Baltimore: Johns Hopkins University Press, 2003.

Woody, Thomas. History of Women's Education in the United States. Vol. 2. New York: The Science Press, 1929.

Zboray, Ronald J. A Fictive People: Antebellum Economic Development and the American Reading Public. New York: Oxford University Press, 1993.

Zuckerman, Michael et al., "Deference or Defiance in Eighteenth Century America?" Journal of American History 85, no. 1 (June 1998): 13-43.

Charleston Library Society Journal, 1759-1780 \& 1783-1790.

Charleston Library Society Minute Book, 1759-1780. 
Minutes of the Trustees of the College of Charleston

[Anon] The Defense of Injur'd Merit . . . n.p., 1771.

Wheelock, Eliazur. A Brief Narrative of the Indian Charity-School in Lebanon in Connecticut, New England ... London, 1767 [Boston, 1763].

White, George. ed. and comp., Historical Collections of Georgia: Containing the Most Interesting Facts, Traditions, Biographical Sketches, Anecdotes, etc., Relating to its History and Antiquities, from its First Settlement to the Present Time. New York: Pudney \& Russell, 1854.

Board of commissioners of the Town of Washington and Academy

(Wilkes County, GA), Minutes, 1784-1808.

William and John Preston Papers, Duke,

Miscellaneous folder

Correspondence 1817-1960

John Preston to William Preston, Rural Valley, May 20, 1817.

John Preston to William Preston, Albemarle, March 25, 1819.

Campbell Family Papers

Box 1: Correspondence, 1774-1811. Folder: Letters: 1785-1795.

Box 41: Writings. Folder: Penitentiaries

Box 41: Writings. Folder: Education and the Literary Fund

Mt Clio Academy Ledger, 1819-1835

Washington Academy and Town minutes

Jeremiah Evarts Papers, 1830

Evarts to Eleazar Lord, Boston, January 16, 1830.

Return J. Meigs Papers, 1802-1814

Meigs to Maj. Lovely, Cherokee Station, Brownsville, GA, February 20, 1802.

Francis Gilmer Notebook and Journal, 1815-1822

Elias Cornelius Papers, 1816-1829

Elias Cornelius to Sally Cornelius, Litchfield, Conn., June 12, 1816.

Cornelius to Secty of the American Board of Missions, Choctaw Agency, December 2, 1817

David Henley Papers, 1791-1817

David Henley to James Robertson, Nashville, June 19, 1797

Permit for John Chisolm to enter the Cherokee Country

Acts of the General Assembly of the State of Georgia . . 1799.

Louisville: Printer to the State, 1799.

Acts of the General Assembly of the State of Georgia . . 1817. Milledgeville: State Printer, 1817.

Acts of the General Assembly of the State of Georgia . . 1822. Milledgeville: State Printer, 1822.

Acts of the General Assembly of the State of Georgia . . 1829. Milledgeville: Camak \& Ragland, 1830.

Brainerd Mission School Account Book, Volume 1, 1819-1854. 0000-0214M.

Chattooga County Poor School Records, 1800s-1900s. RG 127-08-000. Georgia Archives.

Edward Oxford Papers. RG 048-01-001.

Journal of the Senate of the State of Georgia . . 1827. Milledgeville: Camak \& Ragland, 1828.

McIntosh County Academy and Free School Accounts, 1821-1827. RG 198-00-000 
“Montgomery County, Ga. Poor or Common School Records, 1835-1840." Photostat, Georgia Department of Archives and History, n.d.

Poor and Academy School Lists, Executive Department, RG 001-01-117.

Richmond County, Poor Schools Book, 1854-1856. RG 221-00-000.

Toomey Collection. RG 048-01-001.

Georgia Historical Society, Savannah, Georgia

[Anonymous,] "Upon Virtue in General, and Female Education and Manners in Particular: Being an Inaugural Dissertation to the Opening an English Academy for young Ladies \& Misses in Savannah the 26th Novr. 1786.”

Chatham Academy Papers

Demere Family Bible

Georgia House of Representatives Papers, 1791

Peter Gordon, A View of Savannah as it Stood March 24, 1734.

Walter C. Hartridge Collection

Henry Ellis Papers

House Family Papers

Hughes-Folsom Papers

James Habersham-Joseph Habersham Miscellaneous Papers

John Johnson Papers

Mary Bosomworth Papers

Minute Book of the Savannah Library Society, 1809-1838

Minute Book of the Savannah Literary Society, 1813-1814

Minutes of the Savannah Female Orphan Asylum

Wayne Stites Anderson Papers

William Richardson Davie Papers, 1758-1819

Benjamin Hawkins Papers, 1790-1813

Box 1 Item 3: Hawkins to Chickasaws, from Camp near Nashville, May 21, 1797.

Box 2 Item 8: Notes on the Creek Agency, 1804-1805

Box 3 Folder 5

Erwin-Floyd Papers

Jeremiah Evarts Diary

Samuel Fayrweather Papers

Fayrweather to Rev Thomas Prince and Rev Thomas Foxcroft, Bethesda, May 25, 1748.

Dugas Papers

A. Dugas to Mr. Frederick E. Dugas, Philadelphia, May 31, 1826.

A. Dugas to Frederick Dugas, Philadelphia, August 22, 1826.

Mrs. E.H. Steele Papers

Mrs. E.H. Steele to Miss Althethea B. Hyde, St. Mary's, Georgia, April 1, 1830.

Hughes-Folsom Papers

Samuel Lewis, Sand Hills, to William Hughes, Waynesboro, August 14, 1819

G. White to William Hughes, from Savannah, GA, February 24, 1819.

Jones Family Papers

Box 4, Folder 56, James Habersham Papers, 1739-1771

James Habersham to John Wesley, Savannah, June 20, 1739

John Johnson Papers

Folder 1, Official journal, 1791-1792:

Folder 2, Letter book, 1791-1792: 
George Houston to Johnson, Savannah, January 9, 1792

Johnson to Sir George Houston, January 9, 1792 (the date of this letter comes from the original in Folder 3, Miscellaneous Papers).

Johnson to George Houston, Savannah, January 13, 1792

Johnson to William Stephens, esquire, Savannah, January 14, 1792

Johnson to Mayor Thomas Gibbons, savannah, January 21, 1792

James Jackson Papers, 1781-1796 (I am using mostly the published versions . . .) [James Jackson] to the public at large, Feb 1792 (though GHQ attributes it January 1792, internal evidence renders that impossible): Citation: Lilla M. Hawes, "Miscellaneous Papers of James Jackson, 1781-1798." GHQ 37, no. 2 (1953): 147-149.

Chestnut College Collection (on Bethesda) MS 1130

James Habersham to Lady Huntington, Savannah, December 31, 1770

James Habersham to Lady Huntington, Savannah, June 5, 1771

"Floor Plan of Mr. Whitefield's House" [n.d.]

Rules and orders for daily and annual schedules for "Bethesda College" n.d. [anon but attributed to Whitefield himself]

Margaret Floyd to Lady Huntington, n.d., n.p. [aft June 1782]

James Habersham to Lady Huntington, Savannah, [illeg date], 1773.

James Habersham Papers (1756-1775 papers also published in Collections of the

GA Historical Society: The Letters of the Honorable James Habersham, v.6):

Folder 1, 18, and 19.

Mary Bosomworth Papers

Henry Ellis Papers

On Gov Reynolds Departure for England [and Ellis's arrival], by “Americanus": Edmund Akin to Henry Ellis, Fort Moore, January 25, 1760:

Gov Henry Ellis to "The King's beloved Men and Head Warriors of the upper and lower Creek Nations," February 9, 1760

Chekilli Paper, 1735

Thomas P. Lockwood. A Geography of South Carolina, Adapted for the Use of Schools and Families. Charleston, 1832.

Resolutions of the Legislature of Georgia, requesting . . . the Extinguishment of the Title of the Cherokee Indians to Land in the State of Georgia. Washington: Duff Green, 1828

Thomas S. Clay. Detail of a Plan for the Moral Improvement of Negroes on Plantations NP, 1833

Charles C. Jones. Tenth Annual Report of the Association for the Religious Instruction of the Negroes in Liberty County, Georgia. Savannah: P.G. Thomas, 1845

The Committee of the Teachers' Society of Georgia, County Lyceums: Designed to Promote Manual Labor Schools, and the General Advancement of Education (Savannah: Thomas Purse, 1833):

Colonial Records of Georgia, v.27 (1937):

Estate of John Lambert Records

Acts of the General Assembly of the State of Georgia ... November and December 1838. Milledgeville, GA: P.L. Robinson, 1839, 148-149.

Abraham Baldwin Papers

DeRenne Family Papers

Egmont Manuscript Typescripts. 
William Stephen, “1809 Plan of Bethesda, Chatham County, Georgia.”

Telamon Cuyler Collection

Anonymous. A New Voyage to Georgia, by a Young Gentleman,

Giving an Account of His Travels to South Carolina, and Part of

North Carolina, To Which Is Added, a Curious Account of the Indians

by an Honourable Person, And a poem to James Oglethorpe. London, 1737.

Anonymous. A Letter from the Revd. Mr. Sergeant of Stockbridge, to Dr. Colman of Boston ... Containing Mr. Sergeant's Proposal of a More effectual Method for the Education of Indian Children; to raise 'em if possible into a civil and industrious People; by introducing the English Language among them; and thereby instilling into their Minds and Hearts, with a more lasting Impression, the Principles of Virtue and Piety. Boston, 1743.

Anonymous. Indian Song of Peace: with a Proposal . . for Erecting Indian Schools... New York, 1752.

Anonymous. The Harlequin Cherokee, or the Indian Chiefs in London. London, 1772.

Buell, Samuel. A Sermon, Preached at East-Hampton, August 29, 1759, at the Ordination of Mr. Samson Occum . . . New York, 1761.

Seuter, Matthaeus. New Ebenezer. Augsburg, 1747.

Timberlake, Henry. Memoirs of Lieut. Henry Timberlake . . London, 1765.

Treaty Held with the Catawba and Cherokee Indians . . . February and March 1756. Williamsburg, VA, 1756.

Stevens/Sanders-Venning/Cogdell Papers

August Hermann Franke, "Pietas Hallensis ..." In George Whitefield, ed. A Continuation of the Account of the Orphan House in

Georgia ... London, 1743.

Whitfield, George. A Further Account of God's Dealings with the Reverend Mr. George Whitefield ... to which is Annex'd a Brief Account of the Rise, Progress, and Current Situation of the Orphan-House in Georgia in a Letter to a Friend. Philadelphia, 1746.

- An Extract of the Preface to The Reverend Mr. Whitefield's Account of the Orphan-House in Georgia: An Extract of Some Letters sent him from the superintendents of the Orphan-House and from some of the Children. Edinburgh, 1746.

Minutes of the Richmond County Academy Trustees

Commissioners of the Free Schools-Reports

John Drayton Executive Journals

Governors' Messages

General Assembly Petitions

General Assembly Committee Reports

"Minutes of the Board of Trustees for Establishing a Public School in Lancaster District and of the Trustees of Escheated Property, August 30, 1800-April 15, 1840.”

Huger Family Papers

Ainsley Hall Papers

Jane Livingston Allen Papers

Andrew Flinn Papers

Anon. Papers Published by Order of the Agricultural Society of South Carolina. 
Columbia, S.C., 1818.

Camden Orphan Society Daybook, 1797-1815

Chester-Clarkson Papers

Childberry School Manuscripts in the Chester-Clarkson Papers

Class Book for the society at Harry's Meetinghouse

Paul Cross Papers

Daniel Canon Edwards Papers

Fort Hill Baptist Church Records, 1792-1899

Holloway Scrapbook

Kincaid-Anderson Papers

Ann Lawrence Papers

Francis Lieber Papers

Mills Atlas, 1825

Minerva Society Papers

Minutes of the Winyah Indigo Society

Mount Zion Society Papers

Edmund Rutledge Papers

Petitions to the General Assembly

Presbyterian Church Minutes, 1759-1846, Black River, Salem, Sumter County

Richard Furman Papers

Rules and Regulations of the Brown Fellowship Society, 1790

South Carolina College Catalogues, 1806-1835

Sumterville Circulating Library Society Papers

Moses Waddel Papers

Thomas Wadsworth Papers

Thomas Waties Papers

Welsh Neck Baptist Church Minutes, 1737-1935

Williams-Chestnut-Manning Papers

Thomas Jefferson Withers Papers

William Johnson's Charleston School Roster, 1767-1768.

William Richardson Davie Papers, 1758-1819

1758-1759 Mission Journal, addresses as a letter to The Revd Samuel Davies, Secty, The Society for Managing the Mission and Schools among the Indians.

John MacKee Papers

Diary

Hawkins Family Papers

Series 1 Correspondence. Subseries 1.1 (1770-1804): folders 8-12.

Jesse Franklin Indian Treaty Papers, 1816

"Journal of the Proceedings ... to hold conferences and settle a treaty or treaties with the Chickasaw and Cherokee Tribes or Nations of Indians."

Proceedings of the Superior Court of Chatham County

South Carolina, 1790, 1810, 1820.

Georgia, 1820, 1830.

Newspapers of microfilm:

Augusta Chronicle and Gazette of the State [Augusta, Georgia]

Charleston Gazette

Charleston Courier

City Gazette and Commercial Daily Advertiser [Charleston]

City Gazette and Daily Advertiser [Charleston] 
Gazette of the State of Georgia

Georgetown Gazette [South Carolina]

Georgia Gazette [Savannah]

Columbian Museum and Savannah Advertiser [Georgia]

Columbian Sentinel [South Carolina]

Georgia State Gazette and Independent Register [Augusta]

South Carolina Gazette

South Carolina Gazette and Country Journal

Draper Manuscripts

Charleston Orphan House Minutes, 1790-1826 (author's own copy)

Charleston Orphan House Indenture Books, 1790-1818 (author's own copy)

Charleston Alms House Minutes, 1801-1828 (author's own copy)

Fellowship Society Minutes and Rules, 1769-1820 (author's own copy)

Published sources on opaque microcard:

Alexander, Caleb. The Young Ladies and Gentleman's Spelling Book.

Hudson, NY, 1802.

Anon. The Second Part of the South Sea Bubble. Boston, 1721.

Barnes, David. A Discourse on Education. Boston, 1803.

Bishop, Abraham. Georgia Speculation Unveiled. Hartford: Elisa Babcock, 1797.

Boucher, Richard. A View of the Causes and Consequences of the American Revolution. London, 1797.

Boudinot, Elias. Poor Sarah, or the Benefits of Religion Exemplified in the Life and Death of an Indian Woman. n.p. [1818].

Buist, George. An Oration Delivered at the Orphan House of Charleston, SouthCarolina, October 18, 1795 ... Charleston, 1795.

Carter, James. Essays on Popular Education. Boston, 1826.

Charlton, Henry T. A Plea for the West: A Sermon Preached before the Missionary Society of the Synod of South Carolina and Georgia. Charleston, 1824.

Coram, Robert. Political Inquiries: To Which Is Added a Plan for the General Establishment of Schools Throughout the United States. Wilmington, 1791.

Cutbush, James. An Oration on Education. Philadelphia, 1812.

Darwin, Erasmus. A Plan for the Conduct of Female Education in Boarding Schools. London 1797.

Doggett, Simeon. A Discourse on Education. 1796.

Edgeworth, Maria. Practical Education. Boston, 1815.

Ellicott, Andrew. The Journal of Andrew Ellicott . . . Philadelphia: Budd and Bartram, 1803.

Franke, Augustus Hermann. Pietas Hallensis ... and extracted in George Whitefield, A Continuation of the Account of the Orphan House in Georgia . . . London, 1743.

Furman, Wood. A History of the Charleston Association of Baptist Churches in the State of South Carolina. Charleston: Hoff, 1811.

Gallagher, Reverend S. F. An Oration on the Anniversary of the Orphan Establishment, October 18, 1798. Charleston, n.d.

Gascoyne, Joel. A true Description of Carolina. London, 1682.

Georgia Mississippi Company. State of Facts: Shewing the Right of Certain Companies to the Lands Lately Purchased by them from the State of Georgia. Philadelphia, 1795. 
Grant, Ann MacVicar. Sketches of Intellectual Education ... Addressed to Mothers ... Containing an Essay on Education of the Poor. Baltimore, 1813.

Holland, Edwin Clifford. A Refutation of the Calumnies Circulated against the Southern and Western States ... Charleston, 1822.

Hollingshead, William. An Oration, Delivered at the Orphan-House of Charleston, South-Carolina, October 18, 1797, Being the Eighth Anniversary of the Institution . . Charleston, 1797.

- The Gospel Preached to Every Creature: A Sermon before the Incorporated Baptist Church in Charleston. Charleston, 1798.

James, William Dobein. A Sketch of the life of Brigadier General Francis Marion, and a History of His Brigade from Its Rise in June, 1780, until disbanded in December, 1782. n.p., [1821].

Johnson, John. The Rape of Bethesda; or The Georgia Orphan House Destroyed: A Poem. Charleston: Markland and McIver, 1792.

Johnson, William, Nugiae Georgicae; An Essay Delivered to the Literary and Philosophical Society of Charleston, South Carolina, October 14, 1815. Charleston, 1815.

Kennedy, Lionel Henry. An Oration Delivered in St. Philip's Church; Before the Inhabitants of Charleston, South-Carolina: On Monday the Fifth of July, 1813 (The Fourth Being Sunday,) in Commemoration of American Independence . . . Charleston: W.P. Young, 44 Broad-Street, 1813.

Mayo, Robert. The Spelling Book. Baltimore, 1819.

Murray, Ann. Mentaria, or the Young Ladies Instructor. New York, 1812.

Peirce, John. The New American Spelling Book. Philadelphia, 1808.

Pickering, Timothy. Timothy Pickering to George Washington, January 8, 1791. Pickering Papers LXI 164-165A

Pope, John. A Tour Through the Southern and Western Territories of the United States. Richmond: John Dixon, 1792.

Ramsay, David. A Dissertation on the Manner of Acquiring the Character and Privileges of a Citizen of the United States. n.p., 1789.

Sandwich, T. A Tractate upon Mental Horticulture, or, The Improvement of the Mind, with An Appendix, Containing Instructions . . . and Also A Catalogue of Cheap and Essential Books. Augusta, GA, 1805.

Toland, John. A Collection of Several Pieces of Mr. Toland . . London, 1726.

Whitfield, George. A Further Account of God's Dealings with the Reverend Mr. George Whitefield ... to which is Annex'd a Brief Account of the Rise, Progress, and Current Situation of the Orphan-House in Georgia in a Letter to a Friend. Philadelphia, 1746.

- An Extract of the Preface to The Reverend Mr. Whitefield's Account of the Orphan-House in Georgia: An Extract of Some Letters Sent him from the Superintendents of the Orphan-House and from some of the Children. Edinburgh, 1746.

Witherspoon, John. Letters on Education. Morristown, NJ, 1815 [1765]. 
Anon. "A New and Accurate Account of the Provinces of SouthCarolina and Georgia (1732)." The Most Delightful Country of the Universe: Promotional Literature of The Colony of Georgia 17171734. Trevor R. Reese, ed. Savannah, GA: The Beehive Press, 1972, 115-156.

Atkin, Edmond. Indians of the Southern Frontier: The Edmond Atkin Report and Plan of 1755. Wilbur R. Jacobs, ed. Columbia, SC: University of South Carolina Press, 1954.

Baine, Rodney M. The Publications of James Edward Oglethorpe. Athens: The University of Georgia Press, 1994.

Bartram, William. Travels Through North \& South Carolina, Georgia, East \& West Florida" the Cherokee Country, the Extensive Territories of the Muscogulges, or Creek Confederacy, and the Country of the Chactaws. Pennsylvania, James \& Johnson 1791. Francis Harper, ed. New Haven, CT: Yale University Press, 1958. Reprint, Athens: University of Georgia Press, 1998.

Bosomworth, Thomas. "Journal of Thomas Bosomwoth." In William L. McDowell, ed. Documents Relating to Indian Affairs. Columbia, SC: South Carolina Department of Archives and History, 1970, 268-294.

—. "Second Journal of Thomas Bosomworth." In William L. McDowell, Jr., ed. Colonial Records of South Carolina: Documents Relating to Indian Affairs, May 21, 1750-August 7, 1754. Columbia, SC: South Carolina Department of Archives and History, 1992 [1958], 310-326.

Boudinot, Elias. Cherokee Editor: The Writings of Elias Boudinot. Theda Perdue, ed. Knoxville: University of Tennessee Press, 1983.

Brickell, John. The Natural History of North Carolina. Dublin, 1737 [1969 reprint].

Brown, Catharine. Memoir of Catharine Brown, A Christian Indian, of the Cherokee Nation. William Hoole, ed. University, AL: Confederate Publishing, 1986.

Bryan, Andrew. "Andrew Bryan to Reverend Brother, Savannah, December 23, 1800." The Journal of Negro History 1 (January 1916).

Butterfield, L. H., ed. Letters of Benjamin Rush. 2 vols. Princeton, NJ: Princeton University Press, 1951. Rush's general plan of education (1786) is on v1: 388-389.

Calhoun, John C. "Robert Lee Meriwether, William Edwin Hemphill and Clyde Norman Wilson." The Papers of John C. Calhoun. Columbia, SC: Published by the University of South Carolina Press for the South Caroliniana Society, 1959.

Candler, Allen D. The Colonial Records of the State of Georgia. New York: AMS Press, 1970 [1904-1916].

- comp. The Colonial Records of the State of Georgia. Vol. 21. Atlanta, 1904-1916.

Clarke, Jonathan. “Jonathan Clarke to Brother Rippon, Savannah, December 22, 1792.” The Journal of Negro History 1 (January 1916).

Cooper, Thomas, and David McCord, eds. The Statutes at Large of South Carolina: Edited under Authority of the Legislature. Columbia, SC, 1837.

Coulter, E. Merton, ed. The Journal of William Stephens, 1741-1745. 2 vols. Athens, GA: University of Georgia Press, 1958. 
Cuthbert, John. "Deposition of John Cuthbert." In Trevor R. Reese, ed. The Clamorous Malcontents: Criticisms and Defenses of the Colony of Georgia, 1741-1743. Savannah, 1973, p. 162.

DeBow, J. D. B. The Seventh Census of the United States: 1850. Washington: Robert Armstrong, 1853.

Easterby, J. H., ed. The Journal of the Commons House of Assembly, September 12, 1739-March 26, 1741. Columbia, SC: Historical Commission of South Carolina, 1952.

Egmont, John Percival. The Journal of the Earl of Egmont: Abstracts of the Trustees Proceedings for Establishing the Colony of Georgia, 1732-1738. Robert G. McPherson, ed. Athens: University of Georgia Press, 1962.

Ford, Timothy. "Diary of Timothy Ford, 1785-1786." South Carolina Historical and Genealogical Magazine 13.

Foster, Gertrude, comp. “A Documentary History of Education in South Carolina as Revealed in the Manuscripts of the Society for the Propagation of the Gospel in Foreign Parts.” Ed.D., University of South Carolina, 1932.

Gay, John. The Beggar's Opera. Bryan Lougherty and T. O. Treadwell, eds. London: Penguin, 1986 [1728]

Georgia General Assembly. Journal of the Senate of the State of Georgia. Hapeville, GA: Longino and Porter, 1821.

Gordon, Peter. “The Journal of Peter Gordon.” In Reese, ed. Our First Visit to America. Athens: University of Georgia Press, 1963. 1-37.

Grant, Ludovick. "Historical Relation of Facts ..." South Carolina Magazine of Genealogy and History 10 (1909): 59.

Hammerer, John Daniel. An Account of a Plan for Civilizing the North American Indians: Proposed in the Eighteenth Century. Paul Leicester Ford, ed. Brooklyn: Historical Printing Club, 1890.

Hawkins, Benjamin. Letters of Benjamin Hawkins: 1796-1806. Stephen B. Weeks, ed. Collections of the Georgia Historical Society. Vol. 9. Savannah: Georgia Historical Society, 1916.

Hitchcock, Ethan Allen. A Traveler in Indian Territory . . . Grant Foreman, ed. Cedar Rapids, Iowa: Torch Press, 1930.

Historical Commission of South Carolina. Minutes of the Vestry of St. Helena's Parish, South Carolina, 1726-1812. Columbia, SC: Printed for the Historical Commission of South Carolina by the State Co., 1919.

Hodgson, Adam. Remarks During a Journey Through North America . . . Westport, CT, 1970 [1823].

Jones, George Fenwick, and Marie Hahn, eds. Detailed Reports on the Salzburg Emigrants who Settled in America . . Samuel Urlsperger, ed., Vol. 3, 1736. Athens: University of Georgia Press, 1972.

Jones, Thomas. "Thomas Jones to John Lyde, Savannah, September 18, 1740." In Trevor R. Reese, ed. The Clamorous Malcontents: Criticisms and Defenses of the Colony of Georgia, 1741-1743. Savannah, GA: Beehive Press, 1973.

Kennedy, Lionel Henry. An Oration Delivered in St. Philip's Church; Before the Inhabitants of Charleston, South-Carolina. On Monday the Fifth of July, 1813 (The Fourth Being Sunday,) in Commemoration of American Independence... . Charleston: W.P. Young, 44 Broad-Street, 1813. 
Knox, William. "Knox to Governor William Blount [Tennessee, A April 22, 1792.” In F. P. Prucha, ed. American Indian Policy in the Formative Years. Lincoln: University of Nebraska Press, 1970.

Lane, Mills, ed. General Oglethorpe's Georgia: Colonial Letters, 1733-1743. Savannah, GA: Beehive Press, 1975.

Laurens, Henry, Philip M. Hamer, George C Rogers, and David R. Chesnutt. The Papers of Henry Laurens. Columbia, SC: Published for the South Carolina Historical Society by the University of South Carolina Press, 1968-2003.

Liele, George. “George Liele to unknown, Kingston, December 18, 1791.” Journal of Negro History 1 (1916): 71-74.

Locke, John. Essay Concerning Human Understanding. Peter H. Nidditch, ed. Oxford: Oxford University Press, 1975.

—. Political Essays. Mark Goldie, ed. Cambridge: Cambridge University Press, 1997.

Mackay, Charles. Extraordinary Popular Delusions and the Madness of Crowds. Cambridge: Harvard University Press, 1972 [1841].

Mackay, Hugh. "Deposition of Hugh Mackay, January 19, 1739.” In Trevor R. Reese, ed. The Clamorous Malcontents: Criticisms and Defenses of the Colony of Georgia, 1741-1743. Savannah, GA: Beehive Press, 1973.

Marrant, John. “A Narrative of the Lord's Wonderful Dealings with John Marrant, A Black 1785." In Adam Potkay and Sandra Burr, eds. Black Atlantic Writers of the Eighteenth Century: Living the New Exodus in England and the Americas. New York: Palgrave Macmillan, 1995.

Martyn, Benjamin. Reasons for Establishing the Colony of Georgia . . . London, 1733.

—. "An Appeal for the Georgia Colony (1732)." The Publications of James Edward Oglethorpe. Rodney M. Baine, ed. Athens: University of Georgia Press, 1994.

Mauelshagen, Carl, and Gerald H. Davis, eds. and trans. Partners in the Lord's Work: The Diary of the Two Moravian Missionaries in the Creek Indian Country, 1807-1813. Atlanta: Georgia State College, 1969.

Oglethorpe, James. "Account of the Provinces of South Carolina and Georgia (1732)." The Publications of James Edward Oglethorpe. Rodney M. Baine, ed. Athens: University of Georgia Press, 1994.

Pickering, Timothy. Timothy Pickering to George Washington, January 8, 1791, Pickering Papers LXI 164-165A.

Potter, Elam. “An Account of Several Nations of Southern Indians: In a Letter from Reverend Elam Potter to Reverend Dr. Stiles, A.D. 1768." Massachusetts Historical Society Proceedings, 1st Ser., 10 (1809).

Reese, Trevor R., ed. Our First Visit to America: Early Reports from the Colony of Georgia. Savannah, GA: Beehive Press, 1974.

Schoepf, Johann David. Travels in the Confederation [1783-1784]. Alfred J. Morrison, trans. and ed. Philadelphia: William J. Campbell, 1911.

Schweninger, Loren, ed. The Southern Debate over Slavery, Volume 1: Petitions to Southern Legislatures, 1778-1864. Chicago: University of Chicago Press, 2001.

South Carolina General Assembly. Journal of the Senate of the State of South Carolina. Columbia, 1800. 
Sparkman, Mary A. The Charlestown Directory for 1782 and the Charleston Directory for 1785. Richmond: Virginia State Library, 1951.

Stephens, William. The Journal of William Stephens, 1741-1743: Two Volumes. Athens: University of Georgia Press, 1958.

Stuart, James. Three Years in North America. New York, 1833.

Talifer, Patrick et al., "A True Historical Narrative of the Colony of Georgia in America ...” Charleston, SC, 1741.” In Trevor R. Reese, ed. The Clamorous Malcontents: Criticisms and Defenses of the Colony of Georgia, 1741-1743. Savannah: Beehive Press, 1973.

Van Horne, John C., ed. Religious Philanthropy and Colonial Slavery: The American Correspondence of the Associates of the Late Dr. Bray, 1717-1777. Urbana, IL: University of Illinois Press, 1985.

Washington, George. "Circular to the State Governments Newburgh, June 8, 1783.” In Joseph Rhodehamel, comp. George Washington: Writings. New York: Library of America, 1997.

Watkins, Robert, and George Watkins, ed. and comp. Digest of the Laws of the State of Georgia ... Philadelphia: Aitken, 1800.

Wesley, Charles. The Early Journal of Charles Wesley. John Telford, ed. London: Charles H. Kelly, 1909.

Wesley, John. The Journal of the Reverend John Wesley. Vol. 1. Nehemiah Curnock, ed. New York: Charles H. Kelly, 1909.

—. The Letters of the Rev. John Wesley, A.M . ., Vol. 1. London: Epworth Press, 1931.

Windley, Lathan A. Runaway Slave Advertisements: Georgia. Westport, CT: Greenwood Press, 1983.

Wood, Virginia Steele. McIntosh County Academy, McIntosh County, Georgia: Minutes of the Commissioners (1820-1875), Account Book of Students (1821-1834). Belmont, MA: Greenwood Press, 1973.

Woodmason, Charles. The Carolina Backcountry on the Eve of the Revolution: The Journal and Other Writings of Charles Woodmason. Richard James Hooker, ed. Chapel Hill, NC: University of North Carolina Press, 1953. 